\author{
UNIVERSIDADE DE SÃO PAULO \\ FACULDADE DE FILOSOFIA, LETRAS E CIÊNCIAS HUMANAS \\ DEPARTAMENTO DE GEOGRAFIA \\ PROGRAMA DE GEOGRAFIA FÍSICA
}

\title{
A PAISAGEM NO ENSINO DE GEOGRAFIA: \\ Uma Estratégia Didática a partir da Arte
}

JACQUELINE MYANAKI 


$$
\text { UNIVERSIDADE DE SÃO PAULO }
$$

FACULDADE DE FILOSOFIA, LETRAS E CIÊNCIAS HUMANAS

DEPARTAMENTO DE GEOGRAFIA

PROGRAMA DE PÓS-GRADUAÇÃO EM GEOGRAFIA FÍSICA

\title{
A PAISAGEM NO ENSINO DE GEOGRAFIA: Uma \\ Estratégia Didática a partir da Arte
}

\author{
JACQUELINE MYANAKI
}

\begin{abstract}
Dissertação apresentada ao Programa de Pós-Graduação em Geografia Física, do Departamento de Geografia, da Faculdade de Filosofia, Letras e Ciências Humanas da Universidade de São Paulo para obtenção do título de Mestre em Geografia.
\end{abstract}

Orientação: Prof $^{a}$ Dr $^{a}$ REGINA ARAÚJO DE ALMEIDA

São Paulo 
Autor: Jacqueline Myanaki Título: A PAISAGEM NO ENSINO DE GEOGRAFIA: Uma Estratégia Didática a partir da Arte Instituição: FFLCH-USP-Departamento de Geografia Área de Concentração: Geografia Física Orientadora: Prof ${ }^{a} \mathrm{Dr}^{\mathrm{a}}$ Regina Araújo de Almeida Data: 11

Banca: 


\section{AGRADECIMENTOS}

Eu gostaria de deixar registrado meus sinceros agradecimentos a todas as pessoas que direta ou indiretamente contribuíram na construção desse trabalho...

... à minha orientadora e amiga Regina Araújo de Almeida, minha gratidão pelo apoio e compreensão nas horas mais difíceis dentre toda a ajuda oferecida;

... à CAPES, pelo auxílio através da Bolsa de Estudos;

... ao Edu, por tudo, pelo incentivo, pelas críticas, por me "instigar a deixar de andar como caranguejo", meu grande beijo e amor;

... ao Professor Felisberto Cavalheiro por me acolher durante o PAE;

... à Profa Cristina Pietraróia pela ajuda e pelo valioso empréstimo de um dicionário quando esta trajetória ainda se esboçava;

... a todo o pessoal do Departamento de Geografia que trabalha para que tudo dê certo;

... à equipe da AVT e do LEMADI, pelo apoio nos vários trabalhos realizados;

... ao Bira, meu grande amigo, pelo empenho e ajuda nos experimentos;

... à Sônia, obrigada pelos livros, pelo apoio na escola e pelo alto astral;

... à Mônica pelos contatos, pela amizade e carinho;

... a todos os professores e alunos que participaram diretamente desse trabalho e aos que indiretamente me inspiraram na sua realização;

... à Prof ${ }^{a}$ Nídia N. Pontuschka, um especial agradecimento pela atenção e carinho em diversos momentos;

... aos meus pais, irmãos e familiares que são meus pilares e fonte de energia;

... e a todos os amigos que ajudam justamente por serem amigos, mas que não é possível enumerar nesse momento, fica meu beijo no coração de todos vocês! 


\section{RESUMO}

Esse trabalho propõe um caminho para viabilizar a articulação entre geografia e arte na prática de ensino de geografia no ensino fundamental, a partir do experimento de um conjunto de atividades enfocadas no estudo da paisagem geográfica, nas noções básicas conceituais e sua percepção, utilizando reproduções de quadros de pintores brasileiros.

O experimento foi realizado, na sua maior parte, com alunos de $6^{a}$ série de diferentes instituições em duas etapas bem definidas. Na primeira etapa, o roteiro de atividades foi desenvolvido com três turmas de três escolas diferentes e cujos professores participaram como observadores e coadjuvantes durante a aplicação das atividades. Na segunda etapa o roteiro foi desenvolvido de maneira autônoma por sete professores de cinco instituições que receberam antecipadamente o material e as instruções necessárias e assistência à distância, quando solicitada.

Os resultados das duas etapas demonstraram que é possível articular arte e geografia no estudo da paisagem geográfica de maneira a ampliar a capacidade de percepção e apreensão da paisagem geográfica, bem como sobre as manifestações artísticas, além dessa estratégia representar um aumento no entusiasmo e despertar o interesse dos alunos para o processo de construção do conhecimento.

PALAVRAS-CHAVES: Geografia, Ensino, Paisagem, Artes, Interdisciplinaridade. 


\begin{abstract}
This work proposes a means of attaining a synthesis between Geography and Art in the field of Geography teaching at the primary and intermediate levels. It is based on an experiment comprising of a group of activities focusing on the study of basic conceptual notions and perception of geographic landscape, using paintings by Brazilian artists as a reference.
\end{abstract}

The experiment was mostly carried out in two distinct, well-defined stages with students studying in the $6^{\text {th }}$ grade at different institutions. In the first stage, a series of activities was developed with three groups from three different schools. The groups' teachers participated as observers and assistants during the completion of the activities. In the second stage, the activities were developed independently by seven teachers from five institutions that received the material and all the necessary instructions beforehand, as well as long distance assistance, when requested.

The results of the two stages show that it is possible to combine Art and Geography in the study of geographic landscape in such a way as to increase students' ability to perceive and understand geographic landscape, as well as artistic expression, and at the same time help to stir their enthusiasm and interest toward the processes of knowledge building.

KEY WORDS: Geography, Teaching, Landscape, Art, Interdisciplinary. 


\section{Sumário}

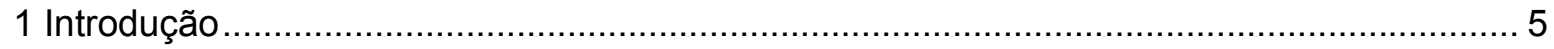

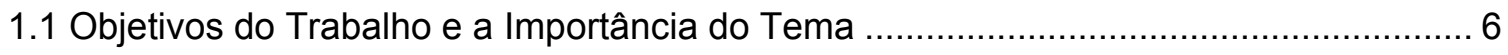

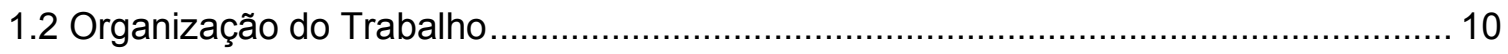

2 Paisagem e Geografia: Histórico e Novas Abordagens ..................................................... 13

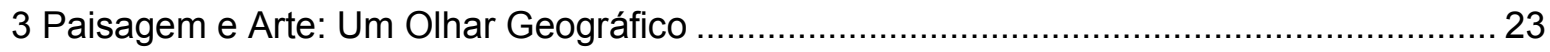

4 Geografia, Arte e Percepção no Ensino: Uma Proposta de Prática Didática ........................ 33

5 Roteiro de Atividades: A Realização do Experimento ..................................................... 40

5.1 Organização e Elaboração do Roteiro de Atividades................................................ 41

5.1.1 Os Quadros: Olhares sobre São Paulo .................................................................. 42

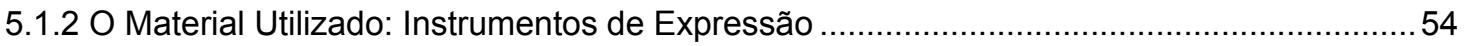

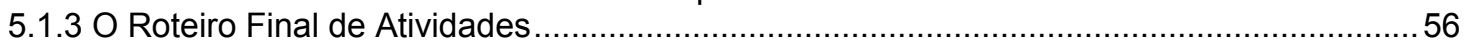

Atividade A - Desenhando e pintando a vista da janela......................................................56

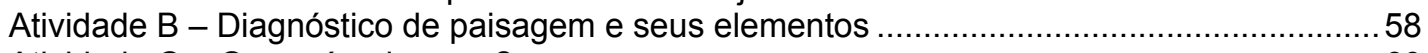

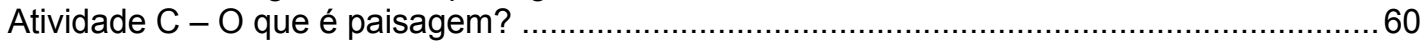

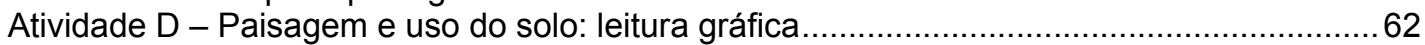

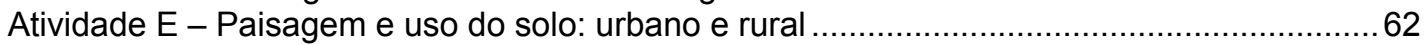

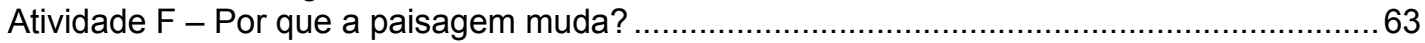

Atividade G - Novo olhar sobre o desenho e a pintura ...................................................6

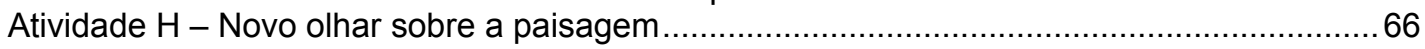

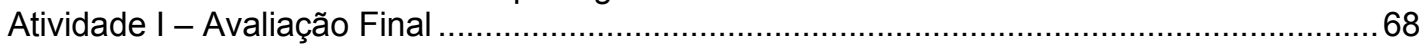

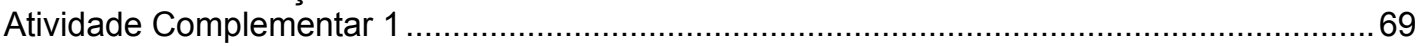

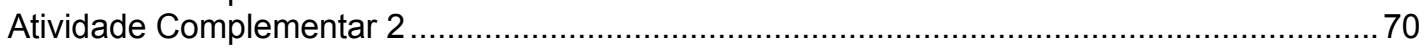

5.2 Etapa 1 dos Experimentos: Caracterização das Escolas e Alunos ............................... 74

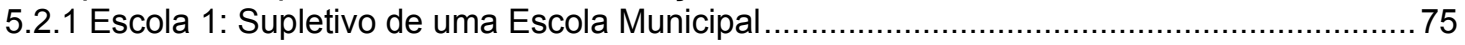

5.2.2 Escola 2: Uma Escola Particular .................................................................................... 77

5.2.3 Escola 3: Uma Turma Regular de Escola Pública ........................................................ 78

5.3 Etapa 2 dos Experimentos: Autonomia do Roteiro de Atividades............................... 79

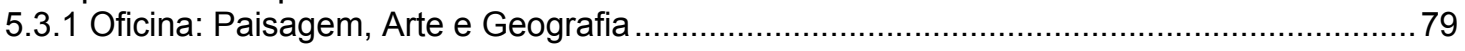

5.4 A Utilização de Recursos da Informática no Conjunto do Trabalho .............................. 82

6 Resultados: A Noção do Conceito de Paisagem a partir dos Experimentos ....................... 84

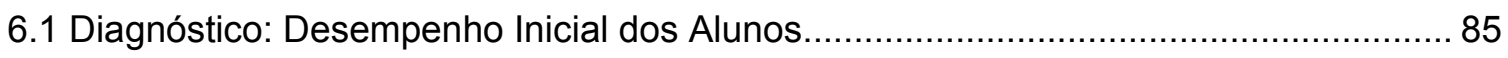

6.2 Resultados das Atividades: Desempenho dos Alunos a Partir das Propostas

Realizadas..... 
6.3 Avaliação dos Professores: Participação e Desempenho .......................................... 110

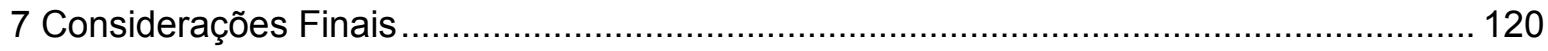

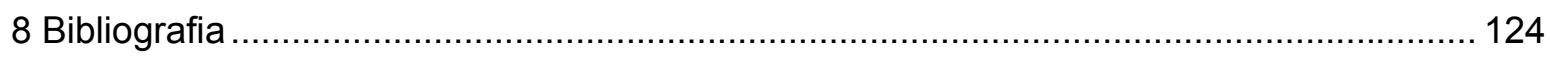

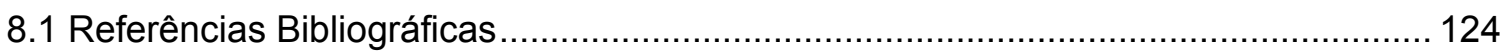

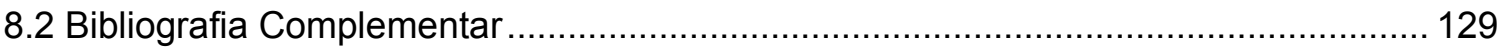

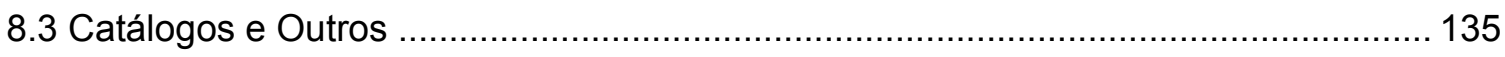

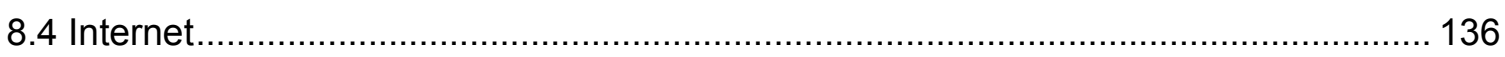

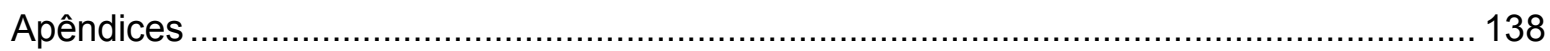

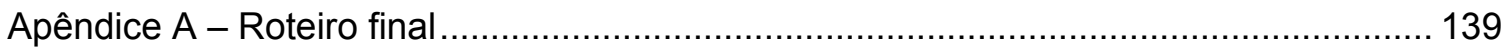

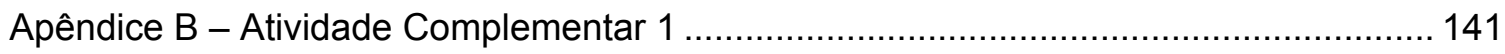

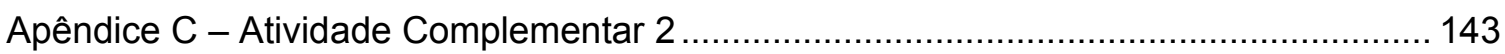

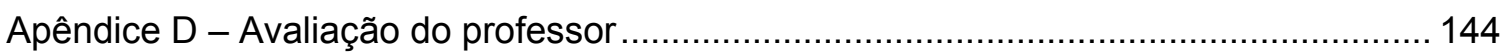

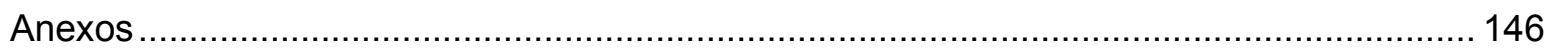

Anexo A - Textos da Atividade Complementar 2 ….................................................. 147

Anexo B - Modelo de Reprodução de Quadro ............................................................ 148

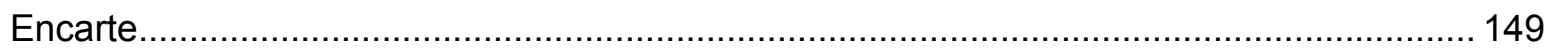




\section{Lista de Figuras}

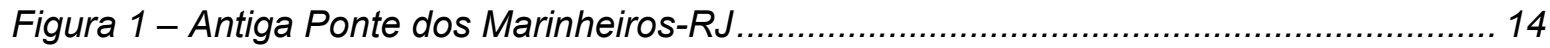

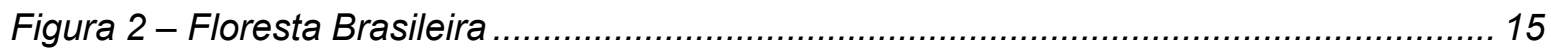

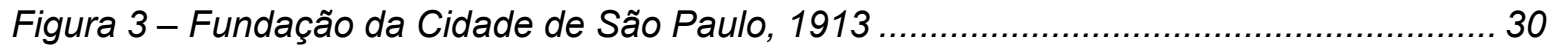

Figura 4 - Rampa do Porto do Bispo em Santos, 1900 ..................................................... 31

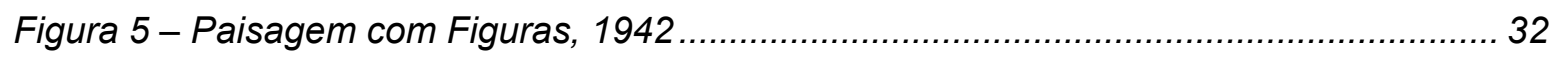

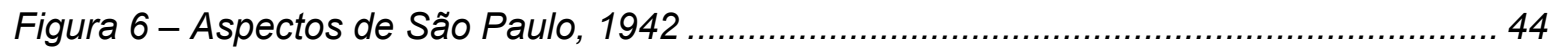

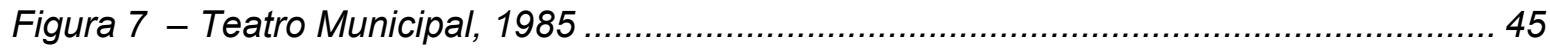

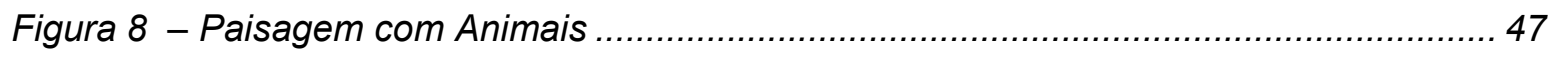

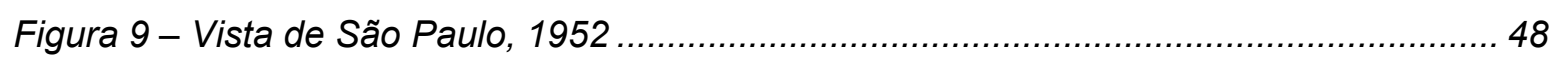

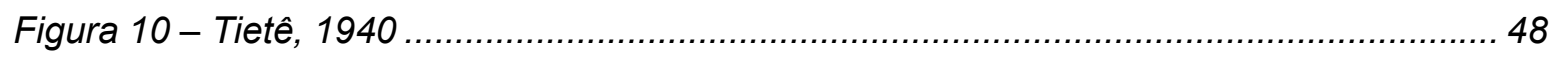

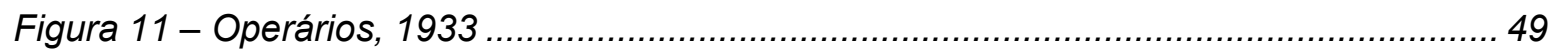

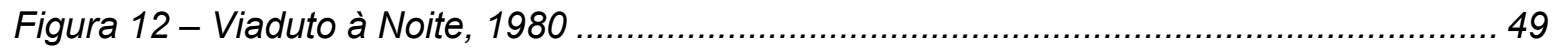

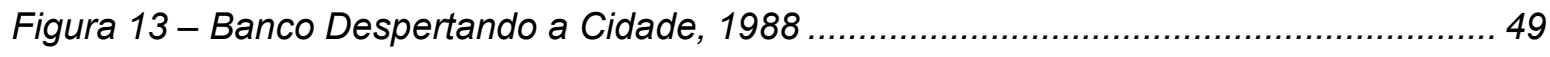

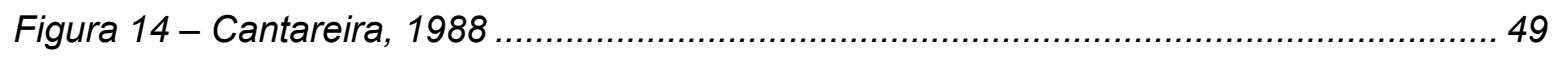

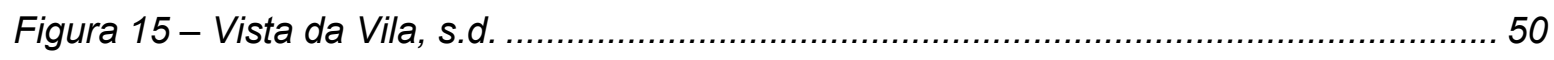

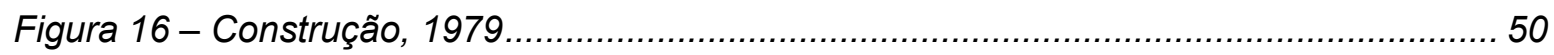

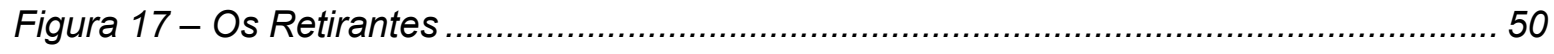

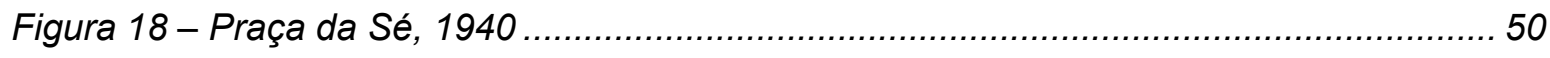

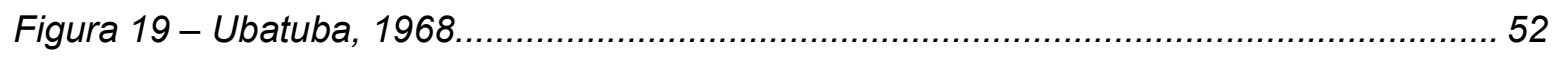

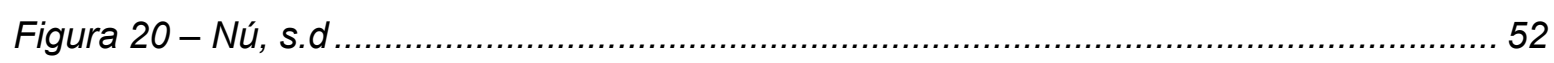

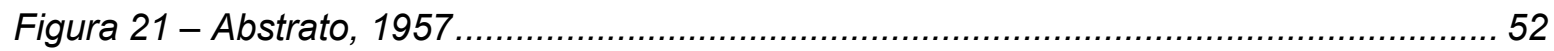

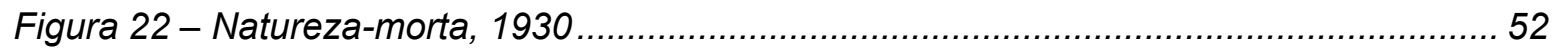

Figura 23 - Retrato de Carlos Drummond de Andrade, 1936......................................... 53

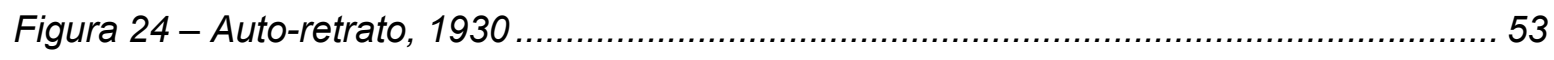

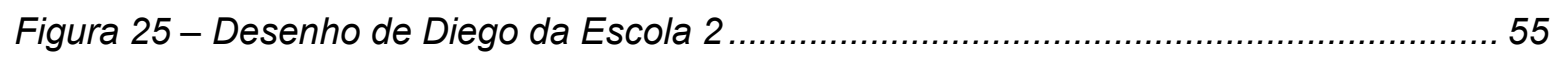

Figura 26 - Desenho de Ricardo da Escola 2 ..................................................................... 55

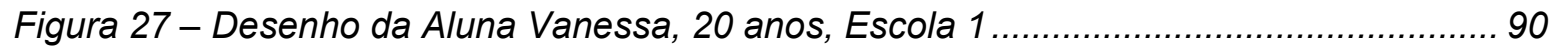

Figura 28 - Desenho do Aluno Jhonatan, 12 anos da Escola 3 ........................................ 91

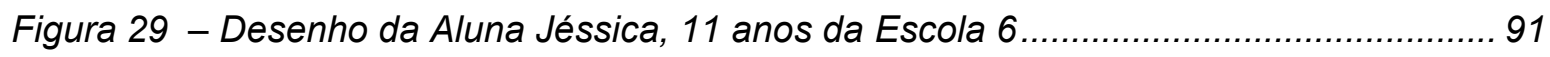


Figura 30 - Desenho 1 do Aluno Adinilson, 28 anos, Escola 1 .......................................... 104

Figura 31 - Desenho 2 do Aluno Adinilson, 28 anos, Escola 1 ....................................... 104

Figura 32 - Fotografia com Vista da Passarela Próxima à Escola 1 ................................. 105

Figura 33 - Desenho da Aluna Rosiclem, 23 anos, Escola 1 .......................................... 106

Figura 34 - Desenhos 1 e 2 do Aluno Cléber, 17 anos, Escola 1 ..................................... 106

Figura 35 - Desenho 1 do Aluno Cláudio, 37 anos, Escola 1 .......................................... 107

Figura 36 - Desenho 2 do Aluno Cláudio, 37 anos, Escola 1 ......................................... 107

Figura 37 - Desenhos 1 e 2 do Aluno Airton, 13 anos, Escola 5 ....................................... 108

Figura 38 - Desenhos 1 e 2 da Aluna Priscila, 12 anos, Escola 5 ................................... 108

Figura 39 - Desenho da Aluna Daiane, 17 anos, ONG 8.............................................. 109

Figura 40 - Desenho do Aluno Roger, 17 anos, ONG 8 ............................................... 109

\section{Lista de Quadros}

Quadro 1 - Síntese das Atividades do Roteiro Final...................................................... 42

Quadro 2 - Síntese das Atividades Distribuídas nos Experimentos .................................... 73

Quadro 3 - Síntese da $2^{a}$ Etapa dos Experimentos ....................................................... 81

\section{Lista de Gráficos}

Gráfico 1 - Conceito de Paisagem Anterior às Atividades................................................. 86

Gráfico 2 - O que os Alunos Afirmam que Aprenderam ..................................................... 96

Gráfico 3 - Atividades mais Cansativas na Opinião dos Alunos ....................................... 98

Gráfico 4 - Atividades mais Interessantes na Opinião dos Alunos.................................... 100 


\section{Introđução}

"O sábio leva a cabo suas atividades sem a ação e transmite seus ensinamentos sem palavras."

Lao Tsé

Este trabalho é resultado de uma inquietação surgida durante a prática do trabalho diário em sala de aula como professora de educação artística e geografia no ensino fundamental e médio ${ }^{1}$. O cotidiano do processo ensino-aprendizagem em duas áreas do conhecimento aparentemente tão diversas, na prática, revertia-se com freqüência, em intercâmbios de conteúdos e estratégias.

$\mathrm{Na}$ procura por compreender mais claramente esses momentos em que a arte e a geografia dialogavam com naturalidade em algumas das atividades didáticas é que este trabalho buscou levantar hipóteses acerca da articulação entre arte e geografia no estudo da paisagem geográfica, a fim de verificar as possibilidades de integrar conteúdos e estratégias e suas implicações na qualidade do aprendizado e na formação geral do educando, no estímulo do trabalho em sala de aula para professores e alunos e as implicações pedagógicas advindas dessa proposta.

Para refletir e responder a essas questões, a metodologia aliou experimentos práticos em sala de aula com a pesquisa teórica, o levantamento bibliográfico

\footnotetext{
${ }^{1} \mathrm{O}$ ensino fundamental, no momento dessa pesquisa (2000-2003), está dividido em dois ciclos, sendo que $\circ 1^{\circ}$ ciclo compreende as séries iniciais de $1^{\mathrm{a}}$ a $4^{\mathrm{a}}$ e $\circ 2^{\circ}$ ciclo corresponde ao período da $5^{\mathrm{a}}$ até a $8^{\mathrm{a}}$ série. $\mathrm{O}$ ensino médio compreende as três séries seguintes ao ensino fundamental, conhecido no passado como colegial.
} 
abrangendo arte, geografia, ensino e outros temas que orbitam em torno dessas áreas de conhecimento e que estão nos limites do objeto da pesquisa, como, por exemplo, psicologia e filosofia. $\mathrm{O}$ objetivo não foi ajustar a prática pedagógica aos pressupostos teóricos, mas sim buscar nesses pressupostos subsídios para a compreensão, adaptação e aperfeiçoamento da experiência em sala de aula.

\subsection{Objetivos do Trabalho e a Importância do Tema}

O objetivo desse trabalho foi verificar como a prática didática com características interdisciplinares ou multidisciplinares envolvendo arte e geografia pode proporcionar mais dinamismo, despertar maior interesse, estímulo e envolvimento dos alunos para a situação de ensino-aprendizagem, resultando em ganho de aprendizado. Além disso, uma proposta didática alternativa na construção do conhecimento e ampliação da percepção que, partindo da arte, desenvolva as habilidades como a de observação, reflexão e interpretação em arte e geografia, ampliando e enriquecendo o repertório e o sentido do conhecimento da paisagem, indo além da linguagem verbal e conceitual.

O século $X X$ já terminou e as transformações passadas e presentes afetam invariavelmente todos os setores da sociedade, as pessoas individualmente e a educação e o ensino. A realidade da sala de aula nesse início do século XXI, traz um conjunto de expectativas para professores e alunos que exigem um esforço de mudança de ambas as partes.

Os avanços e descobertas no setor dos recursos tecnológicos informacionais transformou a comunicação em sinônimo de poder. O volume de informações, a capacidade de armazenamento e a troca dessas informações aumentou muito nos últimos anos. Esse intercâmbio encurtou distâncias, as culturas ficaram mais próximas, as trocas mais intensas e a percepção do mundo não é mais a mesma. 
Nelson Brissac Peixoto aponta o tempo como uma dimensão dessa mudança de percepção sobre o espaço.

\begin{abstract}
As transformações mais radicais na nossa percepção estão ligadas ao aumento na velocidade da vida contemporânea, ao aceleramento dos deslocamentos cotidianos, à rapidez com que o nosso olhar desfila sobre as coisas. Uma dimensão está hoje no centro de todos os debates teóricos, de todas as formas de criação artística: o tempo. O olhar contemporâneo não tem mais tempo. (PEIXOTO, 1996, p.179)
\end{abstract}

Há muito se discute as Teorias da Globalização e autores como Otávio lanni falam em "Sociedade Civil Mundial", Manuel Castels discorre sobre a "Sociedade em Rede", Pierre Lévy aponta a "Inteligência Coletiva" e Milton Santos dedicou-se à análise do "Período Técnico-Científico e a Universalização da Sociedade". O fato é que esse fenômeno do intercâmbio entre as culturas tem se acelerado bastante e alguns autores identificam essas mudanças, baseadas na informação, como pósmodernismo.

À parte o volume de críticas contrárias e favoráveis, o pós-modernismo é comumente identificado como um período de propostas interdisciplinares para todas as áreas do saber e fazer.

Embora não haja consenso nem mesmo quanto ao significado da palavra interdisciplinaridade, que, no cotidiano escolar, muitas vezes se confunde com pluridisciplinaridade e multidisciplinaridade, o que se propõe neste trabalho é um caminho comum para a geografia e a arte no estudo da noção do conceito de paisagem geográfica e sua percepção, que se constitua numa alternativa ao modelo de ensino-aprendizagem praticado nas escolas em geral, e que atualmente apresenta-se se não equivocado, no mínimo desgastado tanto quanto os modelos de construções mentais adotados pela ciência como um todo, como aponta Cláudio Ferraz:

[...] é inquestionável que os modelos e construções mentais, as práticas cotidianas e políticas, os valores ético-morais, os embates em prol dos projetos de sociedade, bem como a crença numa dada estrutura de tempo e 
espaço, dentre outros fatores que caracterizam, de forma genérica, o mundo construído por nós nos últimos 500 anos, apresentam-se nas suas diversas áreas e instâncias, com claras indicações de esgotamento. (FERRAZ, 2001, p. 7)

No Brasil, a nova Lei de Diretrizes e Bases da Educação Nacional de 1996 estabelece alguns princípios básicos nos quais recomenda-se que o ensino se guie, dentre eles o "pluralismo de idéias e de concepções pedagógicas"². No intuito de orientar e servir de apoio à implementação da prática educacional, os Parâmetros Curriculares Nacionais têm capítulos especiais dedicados aos Temas Transversais e às Tecnologias da Comunicação, que apontam para uma das formas de traduzir o princípio do pluralismo de idéias e de concepções pedagógicas.

Porém, da teoria à realidade da sala de aula, o que ocorre são tentativas isoladas de implementar práticas interdisciplinares e o uso de tecnologias como o computador, que nem sempre correspondem ao idealizado já que ficam limitadas, seja pela falta de recursos, seja pela própria dificuldade em traduzir conceitos em práticas pedagógicas ou ainda outras razões, como falta de motivação de professores e alunos.

A intenção desse trabalho é propor e analisar uma forma de articular os conteúdos de arte e geografia que pode, de acordo com a disponibilidade dos agentes envolvidos, resultar em prática interdisciplinar, envolvendo intercâmbio de métodos de investigação entre a geografia e as artes, rompendo com a compartimentação do ensino apontada por Machado:

Uma das características mais marcantes do trabalho escolar é sua organização em disciplinas. Fora da escola, os acontecimentos são sempre globais, multifacetados; ao adentrarem a mesma, esfacelam-se em numerosas disciplinas. (MACHADO, 1993, p. 103)

\footnotetext{
${ }^{2}$ Art $3^{\circ}$, item III do Título II - Dos Princípios e Fins da Educação Nacional da LEI n 9.394/96, de 20 de dezembro de 1996.

${ }^{3}$ MACHADO, Nílson José. Informática nas Escolas: muito além do "sim e do não". Revista São Paulo em Perspectiva. São Paulo: Fundação SEADE, Vol 7, n 1, p. 98-105, jan-mar, 1993. O texto discorre sobre a informática educativa, a utilização de computadores na escola e o caráter interdisciplinar da linguagem da informática. A importância da informática na realização dessa pesquisa e seu potencial de uso estão descritos no capítulo 5 desta dissertação.
} 
Apesar de paisagem não ser uma categoria universal do pensamento (CLAVAL, 2000, p. 57, In: ROSENDAHL \& CORREAA, 2001a), trata-se de um conceito polissêmico que permite uma abordagem conjunta de várias áreas do conhecimento incluindo arte e geografia. No caso dessa pesquisa, a arte limita-se a uma seleção de quadros de artistas brasileiros, ou seja, uma abordagem da paisagem em duas dimensões e a geografia propõe uma ampliação dessa abordagem inserindo a percepção e o estudo da terceira dimensão da paisagem.

Estudar a paisagem é um caminho para perceber simultaneamente o conjunto de elementos que estão interagindo na construção do espaço. Associar esses elementos às paisagens pintadas por artistas brasileiros pode ser uma forma de ampliar a percepção dessa paisagem, além de um esforço em desenvolver o interesse e a motivação dos alunos para as manifestações artísticas nacionais.

Sabe-se que a tarefa do professor de geografia e do professor de artes vai além do conteúdo relacionado à paisagem e aos pintores brasileiros, respectivamente. Porém, a partir dessa relação mínima pode-se estabelecer um referencial para a prática de ensino de ambos, sendo que esse trabalho está concentrado prioritariamente nas necessidades do professor e do aluno em geografia, dada a natureza do vínculo dessa dissertação com o Programa de Pós-Graduação do Departamento de Geografia.

Trata-se de demonstrar a validade do intercâmbio entre arte e geografia no que se refere a estratégias didáticas e também a demonstração da necessidade de busca de um caminho que leve ao entendimento e aprendizado e que não seja unicamente através da palavra verbal, mas sim um caminho que esteja em sintonia com a vivência atual das crianças, pois elas são muito mais habituadas à linguagem iconográfica, hoje, do que há alguns anos seus professores o foram: o Sistema Operacional Windows, os desenhos, placas e avisos, toda a mídia televisiva, principalmente, são estímulos presentes no cotidiano das crianças atualmente. 
Colocar os alunos diante de representações de paisagens de pintores brasileiros é proporcionar a eles a oportunidade de experimentar o olhar do pintor sobre a espacialidade de determinado lugar em determinado tempo, no caso a cidade de São Paulo. O confronto entre o olhar do pintor e o olhar do aluno, amplia as possibilidades de percepção e leitura dessa espacialidade. Dar ao aluno a oportunidade de desenhar e pintar essa paisagem irá fazer com que ele exercite ao mesmo tempo seu olhar redutor e seu olhar criativo. Se tomarmos como verdade o fato de que a expressão através das imagens, apesar de limitada, é menos tomada de estereótipos do que a linguagem verbal, então, o exercício do desenhar/ pintar e o trabalho de apreciação de quadros pode ser um excelente caminho para a aprendizagem.

Desta feita, a paisagem representada numa pintura expressa as formas de se olhar o mundo a partir das condições históricas, culturais, políticas, éticas, estéticas, técnicas e tecnológicas que o pintor e o público estavam inseridos. Tal fato, portanto, permite-nos colher noções que, mesmo que a pintura não expresse a realidade em sua inteireza, auxilia a uma melhor compreensão da visão que os indivíduos e a sociedade possuíam de sua espacialidade em determinada época e lugar. (FERRAZ, 2001, p. 154)

\subsection{Organização do Trabalho}

Para o desenvolvimento da pesquisa e dos experimentos foram escolhidos alunos do $2^{\circ}$ ciclo do ensino fundamental, basicamente por dois motivos. Primeiro, o estudo da paisagem pressupõe que o educando possua o domínio mínimo de um conhecimento geográfico do qual trata normalmente o $1^{\circ}$ ciclo $\left(1^{\mathrm{a}}\right.$ a $4^{\mathrm{a}}$ série $)$, é o que pode ser chamado de "alfabetização geográfica" - conhecimentos básicos em cartografia, relevo, hidrografia, clima, vegetação, sociedade, cidades, etc.

O outro fator está relacionado ao momento e à natureza psico-cognitiva da criança do $2^{\circ}$ ciclo: é o momento em que o pensamento lógico, a capacidade de comparar e 
compreender o espaço concebido e a capacidade de abstração, desenvolvem-se. Segundo estudos de Piaget, isso começa a ocorrer por volta dos 11-12 anos, daí a escolha, prioritariamente da $6^{a}$ série, o que concorda também com o conteúdo da maioria dos livros didáticos em que o estudo da paisagem está colocado nos manuais dedicados a essa série.

$\mathrm{Na}$ seleção das instituições e dos alunos que estiveram envolvidos na pesquisa considerou-se a diversidade de perfis, situação sócio-econômica e faixa etária.

Para a aplicação prática foi elaborado um roteiro de atividades que alterna momentos de composição e apreciação em arte com momentos de observação e análise da paisagem representada, percebida e vivida. Para o desenvolvimento das atividades foram selecionados quadros de dois pintores brasileiros de formação e épocas diferentes: Antônio Gomide (1895-1967) - pintor paulista, estudioso de técnicas, materiais e gêneros - e Agostinho Batista de Freitas (1927-1997) - pintor paulista, autodidata, mestre popular, naïf.

O segundo capítulo enfoca a importância do conceito de paisagem para a ciência geográfica, apresenta uma breve contextualização histórica do conceito de paisagem na geografia, destaca a retomada do conceito de paisagem pela Geografia Cultural, e, finalmente trata da importância do conceito e do estudo da paisagem no ensino de geografia, ao nível do ensino fundamental.

O terceiro capítulo traz algumas considerações sobre a relevância da arte no ensino fundamental, a importância da paisagem como gênero da pintura na arte, uma discussão envolvendo as relações sociedade-natureza no histórico das representações paisagísticas e ao final os referenciais da pintura de paisagem na arte brasileira. 
O quarto capítulo trata da articulação entre arte e geografia como uma proposta de prática didática, traz algumas reflexões sobre o processo cognitivo, sobre percepção da paisagem e o processo ensino-aprendizagem em arte e geografia.

O capítulo 5 apresenta na primeira parte o roteiro de atividades e a forma como foi idealizado, os critérios de seleção dos quadros, dos textos e os objetivos de cada atividade como uma etapa do processo de ampliação da percepção e construção da noção do conceito de paisagem geográfica. Na segunda parte e terceira partes estão as descrições das duas etapas do experimento e a caracterização das instituições e indivíduos envolvidos. Na parte final do capítulo estão apresentadas algumas considerações sobre a utilização da informática no conjunto do trabalho.

No capítulo 6 há uma avaliação geral dos resultados obtidos já apontando para as conclusões do trabalho no capítulo 7 e ao mesmo tempo retomando o problema central de forma a analisar criticamente os resultados. 


\section{Paisagem e Geografia: Histórico e Novas A6ordagens}

"As paisagens trazem a marca das culturas e, ao mesmo tempo, as influenciam."

Augustin Berque

A geografia adquiriu status de ciência no século XIX, porém o conceito de paisagem é anterior à organização da ciência geográfica. Em Portugal, a palavra paisagem, apareceu pela primeira vez em 1608, na Itália paesaggio surgiu também no século XVII, na Espanha paisaje é de 1708 e o registro mais antigo das línguas latinas é de 1551, do francês paysage, segundo Holzer (1999, In: ROSENDAHL \& CORREAA, 1999, p. 153).

Os termos paysage, paesaggio, paisaje e paisagem são contemporâneos ao momento em que a paisagem, como gênero da pintura, começa a ser explorada por artistas, portanto, muito mais próximo das artes plásticas do que da geografia.

É do século XIX o maior número de expedições multidisciplinares enviadas ao Brasil com o objetivo de investigar e conhecer detalhadamente o Novo Mundo. Essas expedições eram compostas por cientistas, profissionais de várias áreas e artistas.

Os artistas eram os responsáveis pelo registro das paisagens, flora, fauna e diversidade da população brasileira, num momento em que a fotografia ainda não 
era uma tecnologia amplamente disponível. Expedições como a Missão Austríaca e a Expedição Langsdorff trouxeram para o Brasil Thomas Ender (figura 1), Johann Moritz Rugendas (figura 2), Adrien Aimé Taunay dentre outros artistas, que retrataram as paisagens brasileiras no período.

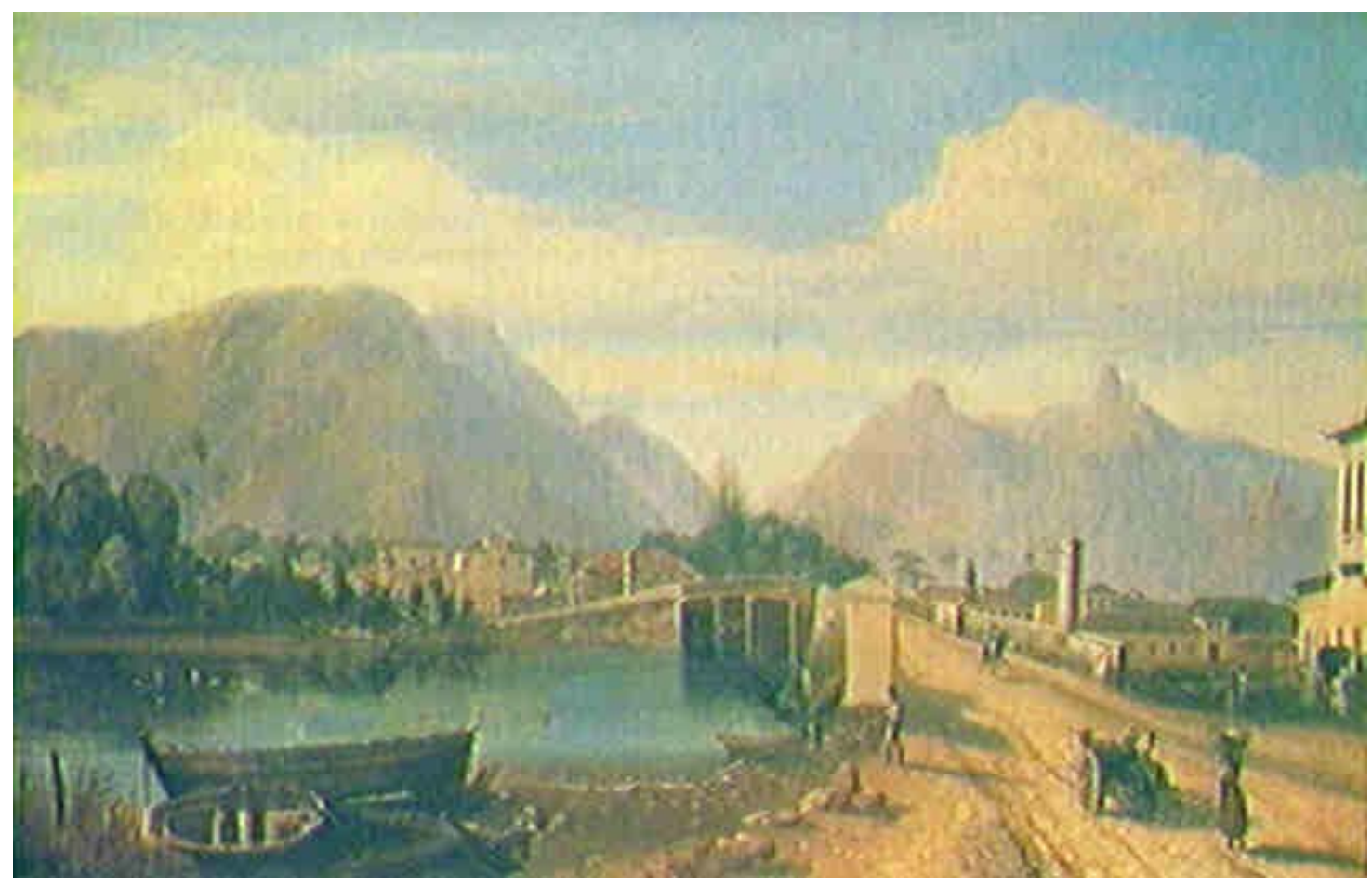

Figura 1 - Antiga Ponte dos Marinheiros-RJ

Thomas Ender

Óleo sobre tela - $35 \times 59 \mathrm{~cm}$ - Coleção Particular Fonte: $<$ http://www.itaucultural.org.br> Acesso em:28 mar. 2002, 20h19 


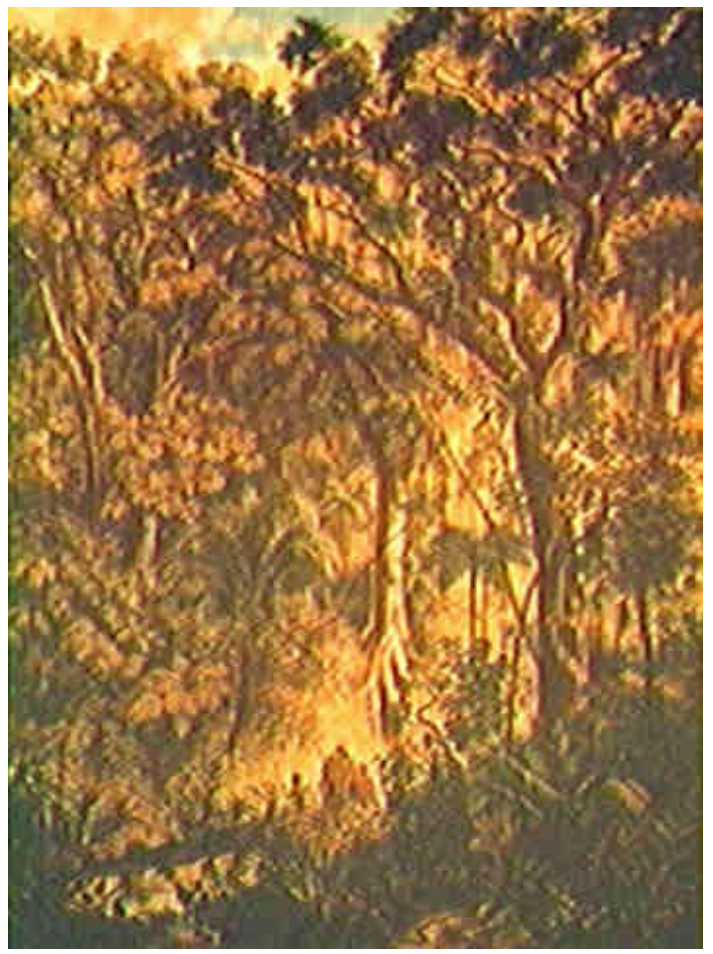

Figura 2 - Floresta Brasileira

(Paisagem na Selva Brasileira com Figuras) Rugendas Óleo sobre tela - $63 \times 50 \mathrm{~cm}$ - Coleção Particular Fonte: <http://www.itaucultural.org.br> Acesso em: 28 mar. 2003, 20h19

Os desenhos e pinturas realizados por esses artistas compunham, em parte, o material científico produzido pelos pesquisadores, naturalistas e viajantes. É assim que a pintura de paisagem esteve junto da investigação científica. Não raro, os geógrafos dessa época, também desenhavam e pintavam. Já no século $X X$, Pierre Deffontaines (1894-1978) realizou mais de 3000 desenhos de paisagens (HÉRODOTE: REVUE DE GÉOGRAPHIE ET DE GÉOPOLITIQUE, 1987, p. 66).

A geografia firma-se como ciência organizada principalmente a partir dos trabalhos de intelectuais alemães, como Ritter e Humboldt. E é do alemão que vem o termo landschaft, um vocábulo medieval, mais antigo que paysage e que significa natureza como evento visual, total e unido, uma associação entre sítio e habitantes. Portanto, um termo mais abrangente e complexo e a partir do qual a ciência acadêmica formulou o conceito de paisagem geográfica, que até o início do século $X X$ esteve no 
centro das investigações geográficas e chegou a ser considerado como o objeto da geografia.

O conceito de paisagem como espaço que se observa de um golpe de vista, foi adaptado pelos geógrafos como sendo uma área fisicamente e culturalmente reconhecível e com algum grau de homogeneidade, podendo ser cartografável e com extensão além de onde a vista alcança. Este seria o conceito de paisagem geográfica adotado pela ciência acadêmica no século XIX.

Mas a geografia como ciência tem uma história de transformações e re-elaboração do seu objeto de estudo e a noção de paisagem passou a ser insatisfatória no século $\mathrm{XX}$, quando outros conceitos como região, território, espaço e lugar tomam o centro das discussões e investigações geográficas, deixando a paisagem à margem dessas discussões até por volta da década de 1970.

A retomada do conceito de paisagem dentro da geografia, aconteceu principalmente no contexto da chamada Geografia Cultural. Uma corrente da geografia que tem Carls Ortwin Sauer como fundador e maior expoente.

\footnotetext{
A geografia cultural distingue, descreve e classifica os complexos típicos de aspectos ambientais, incluindo aqueles feitos pelo homem, que coincidem com cada comunidade cultural, considerando-os como paisagens culturais, e procura origens na história da cultura. Finalmente, pode estudar os processos específicos nos quais estão envolvidas manipulações humanas do meio-ambiente, juntamente com suas implicações para o bem-estar da comunidade e da humanidade, considerando-os como ecologia cultural. (WAGNER \& MIKESELL, 1962, p. 112. In: CORRÊA \& ROSENDAHL, 2000a)
}

Apesar dos textos clássicos da Geografia Cultural serem anteriores à década de 1970, foi nesse período que surgiu um movimento de releitura desses textos e uma retomada do tema da paisagem pela chamada "Nova" Geografia Cultural.

Assim como a ciência geográfica como um todo apresenta diferentes abordagens do conceito de paisagem, também a Geografia Cultural aponta enfoques diversos. 
Denis Cosgrove, por exemplo, considera a paisagem como imagem cultural e se sustenta nos estudos de iconologia de Erwin Panofsky.

\begin{abstract}
A landscape is a cultural image, a pictorial way of a representing, struturing or symbolising surroundings. This is not to say that landscapes are immaterial. They may be represented in a variety of materials and on many surfaces - in paint on canvas, in writing on paper, in earth, stone, water and vegetation on the ground. (DANIELS \& COSGROVE, 1988, p. 1) ${ }^{4}$
\end{abstract}

Outro enfoque é dado por Clifford Geertz, que aponta a paisagem como um texto, "uma configuração de símbolos e signos [...] a ser lido e interpretado como documento social" (COSGROVE \& JACKSON, 1987, p. 19. In: CORRÊA \& ROSENDAHL, 2000b).

Ambas conceituações de paisagem são pertinentes ao desenvolvimento dessa pesquisa, pois apontam para a paisagem como produto cultural e o homem como responsável pela configuração e transformação da paisagem. A metáfora da paisagem como texto e a idéia de paisagem como imagem são compatíveis com a proposta de estudo da paisagem geográfica a partir das representações pictóricas de pintores brasileiros.

A geografia cultural diferencia-se nos métodos e não no "objetivo de descrever e entender as relações entre a vida humana coletiva e o mundo natural, as transformações produzidas por nossa existência no mundo da natureza e, sobretudo, os significados que a cultura atribui à sua existência e às suas relações com o mundo natural." (COSGROVE, 1994, p. 34. In: CORREAA \& ROSENDAHL, 2000b)

Berque (1984, p. 88. In: CORRÊA \& ROSENDAHL, 1998) propõe uma metodologia de estudo da paisagem em geografia cultural, em cinco etapas interligadas e intercambiáveis. Nessa metodologia o homem aparece sempre no coletivo

\footnotetext{
4 "Uma paisagem é uma imagem cultural, uma maneira pictórica de representar, estruturar ou simbolizar o meio. Isso não quer dizer que as paisagens sejam imateriais. Elas podem ser representadas numa variedade de materiais e em várias superfícies - em óleo sobre tela, em escritas sobre papel, em barro, pedra, água e vegetação no solo." (tradução nossa)
} 
sociedade: 1) o inventário eco-geográfico: mede o grau de transformação da natureza pela sociedade; 2) o inventário das representações: como a sociedade percebe e evoca sua relação com a natureza; 3 ) o inventário dos conceitos e valores: como a sociedade concebe e julga o natural, o artificial, o sobrenatural, a natureza humana, etc; 4) o inventário das políticas: como a sociedade gera e como são as instituições de organização das relações; 5) exame sintético: exame das influências recíprocas: política, ética, estética, cultural, etc.

Apesar de se tratarem da mesma área de conhecimento, há diferenças entre a geografia como ciência e o conteúdo de geografia desenvolvido no ensino fundamental. No contexto da escola fundamental, a formação do educando é um referencial forte que impede a simples transferência de métodos da ciência geográfica.

Essa pesquisa buscou aproximar a prática em sala de aula das três primeiras etapas da metodologia proposta por Berque. Por se tratar de um trabalho de construção da noção do conceito de paisagem, a abordagem da geografia cultural permite estabelecer uma relação sujeito/sujeito tendo a paisagem como mediadora dessa relação. Como afirma Berque, a paisagem tem uma marca que é ao mesmo tempo matriz "porque participa dos esquemas de percepção, de concepção e de ação - ou seja, da cultura - que canalizam, em um certo sentido, a relação de uma sociedade com o espaço e com a natureza e, portanto, a paisagem do seu ecúmeno." (BERQUE, 1984, p 85. In: CORRÊA \& ROSENDAHL, 1998).

De acordo com o que foi verificado na prática do magistério e confirmado através de pesquisas acadêmicas realizadas ${ }^{5}$, é comum o conceito de paisagem receber

\footnotetext{
${ }^{5}$ Para mais detalhes sobre a representação do conceito de paisagem no ensino fundamental ver: CARDOSO, Maria Eduarda Garcia. O Conceito de Paisagem no Livro Didático e suas Implicações para o Ensino de Geografia. 1999. Dissertação (Mestrado em Geografia Física) - Departamento de Geografia, Faculdade de Filosofia, Letras e Ciências Humanas da Universidade de São Paulo, São Paulo, 1999 e

CAVALCANTI, Lana de Souza. A Construção de Conceitos Geográficos no Ensino - Uma Análise de Conhecimentos Geográficos em Alunos de $5^{a}$ e $6^{a}$ Série do Ensino Fundamental. 258 p. Tese
} 
tratamento superficial ou mesmo equivocado nos livros didáticos. O trabalho de campo desenvolvido durante essa pesquisa detectou uma maioria de adolescentes e adultos que entendem que paisagem é sinônimo de beleza e natureza, sem distinguir paisagem como gênero da pintura de paisagem geográfica.

Em geral, os manuais didáticos do ensino fundamental têm, no máximo, um capítulo dedicado ao estudo da paisagem e as estratégias limitam-se à apreciação de algumas fotos que ilustram a distinção entre paisagem natural por oposição à paisagem cultural ou a transformação da paisagem ao longo dos anos. Essa classificação, como foi verificado, contribui mais para confundir do que para esclarecer.

A própria produção acadêmica admite que paisagem natural é um conceito ambíguo pois "[...] grosseiramente podemos dizer que a paisagem natural é aquela ainda não mudada pelo esforço humano. Se no passado havia a paisagem natural, hoje essa modalidade de paisagem praticamente não existe mais." (SANTOS, 1988, p. 64) ou como questiona Pierre Monbeig "le paysage naturel, en existe-t-il? Le mot même de paysage implique l'action humaine"6 (apud, SALGUEIRO, 2000, p. 166).

Na perspectiva dos jovens do ensino fundamental, é comum a noção de paisagem natural se confundir com o conceito de natureza. Se paisagem é um conceito que implica a existência humana, então a ação de enquadrar e olhar a paisagem é uma forma de intervenção cultural que anula a idéia de paisagem natural como é apresentada nos livros didáticos. A paisagem que não foi tocada pelo olhar humano é natureza e não paisagem, como afirma o neurologista Oliver Sachs "[...] tudo que vejo é modificado pelo conhecimento, pelos desejos, pela alma [...]"7.

(Doutorado) - Departamento de Geografia da Faculdade de Filosofia, Letras e Ciências Humanas da Universidade de São Paulo, São Paulo, 1996.

6 "a paisagem natural existe? A própria palavra paisagem implica a ação humana." (tradução nossa)

7 Declaração registrada no documentário longa-metragem "Janela da Alma" de João Jardim e Walter Carvalho exibido pela primeira vez no Brasil durante a 25 $5^{\mathrm{a}}$ Mostra BR de Cinema, em outubro de 2001. 
O enfoque normalmente vem inserido nos livros da $5^{\mathrm{a}}$ ou da $6^{\mathrm{a}}$ série e é comum o conceito não ser retomado nos livros das séries seguintes, uma vez que nem mesmo nos capítulos subseqüentes dos manuais em que são discutidos, voltam ao foco central.

O que se nota, portanto, é que assim como o conceito de paisagem deixou o centro das discussões e investigações científicas do objeto geográfico por algum tempo, ele também ficou à margem da geografia das salas de aulas do ensino fundamental ou não foi reorganizado, prevalecendo as metodologias reducionistas que propõem somente a descrição e o enfoque estático da paisagem, suprimindo o aspecto dinâmico e funcional da mesma.

As noções de território, espaço, região e natureza são contempladas com maior freqüência nos livros didáticos, enquanto a paisagem, a conexão e a relação entre diferentes paisagens são superficialmente estudadas.

Embora o conceito de paisagem seja complexo e motivo de pouco consenso entre os geógrafos, uma parcela da ciência geográfica ainda se dedica com seriedade às ambigüidades conceituais relativas à paisagem, a questões mais pragmáticas e estratégicas das transformações da paisagem e sua percepção, sendo considerada objeto de estudo de alguns geógrafos.

A importância do estudo da paisagem, reside no fato de que "se, de um lado, as formas visíveis da paisagem podem dirigir as transformações sociais ou limitar as alternativas de organização do território, de outro lado, as modificações da estrutura social criam sempre novas necessidades, sugerem novas formas e redefinem os valores da paisagem visível" (LEITE, 1994, p.51). Um processo educativo que deseje transformar seus educandos em cidadãos conscientes, atuantes, questionadores e agentes da construção da paisagem, deve empreender esforços na direção do conhecimento e apreensão da mesma. 
Il faut apprendre à chercher les paysages, il faut même apprendre à les dessiner pour saisir leur architecture, mais aussi comprendre pourquoi tel paysage est jugé beau et pourquoi il a été choisi par les media, comprendre aussi, devant un film ou une photo, comment tel cinéaste, tel photographe l'a cadre. II faut savoir-penser les paysages. Tout cela, c'est aussi raisonner en géographe.

Entre les géographes, les écrivains, les poètes et les peintres, il y a, en vérité, plus des accointances et c'est pourquoi les géographes ont aussi des choses à dire sur la peinture, sur le cinema comme sur l'ouvre d'un grand écrivain, surtout s'il parle des paysages. (LACOSTE, 1987, p.7) ${ }^{8}$

Considerando as diferenças entre a abordagem da ciência geográfica e o conteúdo de geografia desenvolvido nas salas de aula do ensino fundamental, a paisagem pode ser melhor apreendida se sua pesquisa for interdisciplinar, pois "[...] our response to nature is depleted when it is detached from aesthetic considerations" ${ }^{\prime \prime}$ (FULLER, 1988, p. 13). Para isso é necessário esclarecer a polissemia do conceito de paisagem, no intuito de identificar a diferença da paisagem geográfica da paisagem como gênero da pintura.

Espera-se que ao olhar para a paisagem geográfica, um aluno de $6^{a}$ série possa ver mais do que um conjunto de elementos desconexos, sem relação entre si e com ele próprio.

Apesar dos Parâmetros Curriculares Nacionais (PCN) tomarem a paisagem como um desdobramento do espaço e considerá-lo como objeto central do estudo geográfico, a abordagem da paisagem sugerida nos $\mathrm{PCNs}$ de geografia ainda é mais extensa e mais profunda do que a que está presente na maior parte dos livros didáticos e do que a que os alunos têm sido submetidos, no universo pesquisado.

\footnotetext{
8 "È necessário aprender a pesquisar as paisagens, é preciso aprender a desenhá-las para entender sua arquitetura, mas também compreender porque tal paisagem é considerada bonita e porque foi escolhida pela mídia, compreender ainda, à frente de um filme ou uma fotografia, como tal cineasta, tal fotógrafo a enquadrou. É necessário saber pensar as paisagens. Tudo isso, é também a argumentação de um geógrafo.

Entre os geógrafos, os escritores, os poetas e os pintores, há, na verdade, muita familiaridade e é por isso que os geógrafos também tem o que dizer sobre a pintura, sobre o cinema como sobre a obra de um grande escritor, sobretudo se ele fala de paisagens." (tradução nossa)

9 “...nossa resposta à natureza é vazia quando está separada das considerações estéticas." (tradução nossa)
} 
A proposta dessa pesquisa é intervir na construção da noção do conceito de paisagem geográfica a partir da arte e não pela arte. É uma proposta que envolve conteúdos de arte mas não os toma como simples ferramenta. São conteúdos desenvolvidos conjuntamente com os conteúdos de geografia visando o estímulo da percepção da paisagem e a ampliação do conhecimento e o esclarecimento sobre a polissemia do conceito de paisagem. 


\title{
3 Paisagem e Arte: Um OChar Geográfico
}

\author{
"Fazer ver algo que se pode conceber e \\ que não se pode ver nem fazer ver: essa é \\ a tarefa da pintura." \\ $\mathcal{N}$ elson Brissac Peixoto
}

Paisagem, na arte, é um termo identificado como um gênero da pintura, é a "representação pictórica de um sítio ao ar livre, no qual a natureza desempenha o papel exclusivo ou preponderante." 10

Assim como na geografia, o conceito de paisagem na arte também se transformou ao longo da história. A concepção de paisagem sofreu oscilações no grau de importância e nos padrões de representação.

A história da humanidade registra formas de representação que podem ser identificadas como paisagens desde as pinturas rupestres do homem pré-histórico que desenhava cenas de caça, colheita, etc. Porém, a pintura de paisagem como gênero da arte de pintar teve seu apogeu no século XIX, chegando a ser considerada "a principal forma de criação artística" do período, nas palavras de Kenneth Clark (1961, p. 15) que considera que "a pintura de paisagem marca as fases da nossa concepção de Natureza" (idem, p.19).

\footnotetext{
${ }^{10}$ Definição de paisagem incluída no painel da exposição do acervo da Pinacoteca do Estado de São Paulo.
} 
Rever a história da pintura de paisagem é, de certo modo, rever elementos da complexa relação homem e natureza. Rougerie \& Beroutchachvili (1991, p. 16) distinguem duas maneiras de conceber as relações entre homem e natureza: a maneira ocidental e a maneira oriental. $\mathrm{O}$ homem ocidental vive frente a frente à natureza enquanto o oriental vive em comunhão com ela.

$\mathrm{Na}$ pintura oriental chinesa do século XIII as paisagens ressaltavam as belezas naturais de acordo com um padrão, de certo modo, pré-estabelecido. O objetivo era cantar os "estados de espírito das paisagens" (GOMBRICH, 1972, p. 110).

Os pintores chineses não se interessavam por detalhes da paisagem a fim de fazer uma pintura que imitasse o mundo real, eles aperfeiçoavam seus traços pintando várias vezes uma árvore, uma rocha ou uma montanha - até chegar a um ideal observando como faziam os mestres e não observando a natureza. Quando estavam aptos, partiam para uma jornada de meditação e observação junto à natureza e só depois é que produziam suas pinturas, fechados em ateliês e tomados pelo espírito da natureza. Havia um padrão de traçado, formas e cores que era ensinado pelos mestres aos iniciantes, a individualidade do artista sobressaía na forma de compor os elementos do quadro e demonstrar o espírito da paisagem captado durante a meditação.

Diferentemente, na arte ocidental, entre os séculos IV a.C. e o século I d.C. os artistas helenísticos pintaram paisagens como cenário secundário para a representação de cenas de grupos humanos ou de investidas militares. Com finalidade apenas decorativa, as paisagens eram compostas de uma série de elementos que integravam uma cena idílica. Essa preferência pelos valores humanos denota o papel secundário desempenhado pelo conceito de natureza no período (CLARK, 1949, p. 19). 
Segundo a classificação de Kenneth Clark (1949) essas pinturas de paisagens helenísticas podem ser consideradas como paisagens simbólicas. São decorativas e a representação da natureza é mediada por símbolos.

No caso da arte ocidental medieval, a percepção direta da natureza poderia suscitar prazeres pecaminosos, altamente reprovados pelo Clero na Idade Média, daí a utilização de símbolos na representação da natureza.

A classificação de Kenneth Clark para a paisagem destaca quatro tipos de paisagens: paisagem simbólica, paisagem dos fatos, paisagem fantástica e paisagem ideal. Como o próprio autor enfatiza, não se trata de uma classificação histórica, desse modo, à medida que houver outros exemplos desses tipos de paisagem no decorrer dessa periodização, elas serão lembradas.

A ascensão da burguesia na Europa, a partir dos séculos XV e XVI, a menor influência da Igreja na vida cotidiana e o desenvolvimento das tecnologias (principalmente de navegação) sugerem uma nova percepção do espaço. A utilização da perspectiva como técnica para a representação da profundidade ofereceu a possibilidade de uma representação de paisagem em duas dimensões, com maior semelhança ao real. Mas as pinturas de paisagem ainda não eram um gênero popular. Os quadros tinham como tema principal o cotidiano, personagens e cenas religiosas e a paisagem como cenário num plano secundário, pois ainda havia uma ruptura clara entre o primeiro plano e plano de fundo das obras. Para Clark, esse intuito de retratar "experiências reconhecíveis" é típico da Paisagem dos Fatos (CLARK, 1949, p. 50).

No final do século XV e início do XVI, Hyeronimus Bosch e Leonardo da Vinci "fizeram um uso constante de certas formas e símbolos perturbantes" e "pintaram aspectos da natureza que exprimiam essas negras convulsões do espírito" (humano) com a intenção de explorar os mistérios da natureza (CLARK, 1949, p. 58). Esses dois artistas realizaram, segundo Clark paisagens fantásticas. 
Os quadros de Bosch são freqüentemente comparados com a produção surrealista do século $X X$, já da Vinci deixou uma obra que vai além da produção de desenhos e pinturas, pois o artista realizou pesquisas e sistematizou conhecimentos em diversas áreas. Seu Tratado da Pintura e Tratado da Paisagem demonstram que Leonardo da Vinci conhecia a paisagem geográfica, além da paisagem como gênero da pintura, pois nesses escritos há descrições de hidrodinâmica associada ao modelado do relevo, além de descrições sobre formação de nuvens, extratos de vegetação, geomorfologia e curso das águas.

O século XVI ao XVII é o período em que as descobertas do Renascimento influenciam ainda mais as representações das paisagens, os artistas passam a se interessar pela paisagem não só como pano de fundo, mas como imitação do mundo real. Porém um pintor que quisesse sobreviver como artista e ganhar notoriedade deveria limitar-se à dedicação aos retratos, às cenas de comunidades camponesas e religiosas principalmente, mas jamais à pintura de paisagem exclusivamente. Somente um artista já estabelecido socialmente dedicava-se ao exercício de pintar paisagens pelo simples prazer pessoal.

Nicolas Poussin (1594-1665), francês, é um dos pintores de destaque do período. Considerado um mestre acadêmico, Poussin era um pintor cartesiano, ou seja, tudo que ele pintava era resultado de muito raciocínio, de busca da ordem e da lógica. $\mathrm{O}$ ideal de paisagem para Poussin vislumbrava a harmonia entre os elementos horizontais e verticais, como porém, linhas verticais são praticamente inexistentes na natureza, a solução encontrada por ele foi inserir elementos da arquitetura nas suas composições, que Clark identificou como paisagens ideais (CLARK, 1949).

Outro pintor de destaque já do século XVII é Claude Lorrain (1600-1682), também francês mas que passou a maior parte de sua vida na Itália. É considerado um mestre da representação realista da natureza, com destaque para as árvores que pintava. Tal foi a importância de seus quadros que, na época, suas pinturas serviam 
de padrão de paisagem para o julgamento da paisagem real. $\mathrm{Na}$ Itália, as pessoas escolhiam os lugares para fazer piqueniques de acordo com as paisagens pintadas por Lorrain e na Inglaterra, os jardins eram modelados também de acordo com seus quadros (GOMBRICH, 1972), uma vez que as paisagens retratavam a natureza em forma de jardim.

$\mathrm{Na}$ Holanda também se destacaram vários mestres, virtuoses, principalmente, da pintura de marinhas, reproduzindo com vigor ondas e nuvens. Os holandeses souberam transformar uma cena simples em uma "visão de repousante beleza" (GOMBRICH, 1972, p. 330) através da capacidade de representar a luminosidade e a beleza do céu, traduzindo fielmente os efeitos de luz com espírito alegre e poético.

Jacob van Ruisdael (1628-1682) é um exemplo de pintor de paisagem do norte europeu, que se especializou em cenas de florestas, nuvens sombrias e sombras da luz ao entardecer.

Até fins do século XVII pintar paisagens era só um passatempo de poucos pintores. Apesar da Reforma Religiosa ter, de certo modo, obrigado os pintores a se ocuparem de outros gêneros que não a pintura religiosa, eles ainda não tinham completa liberdade de escolha de gênero e quase sempre acabavam por vender quadros de retratos.

Somente no século XVIII é que de fato há uma mudança. A pintura passa a ser uma disciplina ensinada em academias e os pintores adquirem autonomia para pintar o que sua imaginação quiser ou então, paisagens, agora não mais como pano de fundo, mas imitações da natureza no plano principal.

Utilizando-se de toda a técnica acumulada até então, diversos pintores paisagistas destacam-se no século XIX. John Constable (1776-1837), inglês, queria ser fiel ao que seus olhos viam, desprezava as convenções de composição, arranjo e cores. $O$ 
destaque de suas obras são as representações de nuvens que a matemática dos períodos anteriores não conseguiu solucionar. É o auge do naturalismo .

Pode-se afirmar que até esse momento a finalidade da pintura foi oferecer o belo ou a verdade ao prazer das pessoas. Ainda que o conceito de belo seja complexo, é fácil compreender porque é comum associar natureza e beleza ao termo paisagem.

No momento em que o gênero de pintura paisagem é tomado de importância no século XIX, a natureza exerce um fascínio sobre os pintores. São eles os encarregados de registrar também as paisagens do novo mundo. $O$ tema das paisagens que já fora inspirado na arquitetura romana e nos jardins, agora passa a se inspirar nas paisagens grandiosas e desconhecidas do Novo Mundo.

William Turner (1775-1851), também inglês, retrata a grandiosidade da natureza, com romantismo e elementos de sua imaginação, já rompendo com os excessos do naturalismo no norte da Europa.

A partir da segunda metade do século XIX inicia-se um movimento de rompimento com os referenciais renascentistas e a geometria perspectivista. $O$ olhar e a percepção do homem sobre o espaço modificam-se frente à experiência do período de intensas descobertas e inovações tecnológicas que começa a se esboçar.

Entre 1850 et 1950, les paysages urbains occupent une place importante dans les différents arts. La rue, le boulevard, le mouvement des hommes et des choses, les réclames et les vitrines, les terrasses de café, le luxe et la pauvreté s'y déclinent sous leurs nombreuses facettes diurnes et nocturnes. (BÉGUIN, 1995, p.17) ${ }^{11}$

A paisagem se modifica, pois as cidades expandem-se e adensam-se. A linha do horizonte é delineada pelo contorno dos edifícios e das chaminés, enquanto os

\footnotetext{
11 "Entre 1850 e 1950, as paisagens urbanas ocupam um lugar importante nas diferentes artes. A rua, a avenida, o movimento dos homens e das coisas, os anúncios e as vitrines, os calçadões dos cafés, o luxo e a pobreza são nas artes declinadas sobre suas numerosas facetas diurnas e noturnas." (tradução nossa)
} 
corredores das ruas e construções se multiplicam. Essa nova relação entre o meio natural e o urbano reflete-se nas representações plásticas das paisagens e elementos como o céu e a luminosidade tomam importância.

No sul da Europa, é a vez dos impressionistas iniciarem experimentos com efeitos de luz e cor. Eles levam seu material ao ar livre e não tem mais a preocupação em fazer cópias fotográficas da paisagem, mas sim captar os efeitos de luz e sombra e, para não perder o momento, utilizam-se de pinceladas rápidas. Os arredores de Paris, as margens do Rio Sena e os parques são alguns dos temas das paisagens que surgem nos quadros.

As novas experiências e descobertas vão aos poucos sendo incorporadas e retratadas nas paisagens: as altas montanhas e os fenômenos da natureza, como os raios.

Preocupado em restituir a ordem do passado, Cézanne (1839-1906) faz uso das relações entre formas e cores para expressar a luminosidade da paisagem, mantendo a harmonia das linhas desprezada pelos impressionistas. Van Gogh (1853-1890), queria expressar o que ele sentia a respeito do que via, não importa se para isso tivesse que deformar os objetos. Ambos abandonaram a idéia de imitação da natureza.

Já os surrealistas queriam compor algo que fosse mais real que o real. Seguindo essa tendência de rompimento com os padrões de representação surgem as pinturas não-figurativas do século $X X$ e outras expressões que acabaram por popularizar a afirmação de F. Dagognet (apud RIOU, 1986) que a paisagem morreu. Mas como afirma Alain Roger, a paisagem não morreu, apenas houve uma transformação, uma adaptação. A tecnologia nos permite falar, hoje, em paisagens subterrâneas, submarinas, aéreas, planetárias, sonoras, olfativas, cinestésicas, virtuais, etc. (ROGER, 2000, p. 38) 
Atualmente, há uma retomada da pintura de paisagem em que o pintor procura evocar sentimentos e emoções muito mais do que a representação pura da natureza, as paisagens são invenções, é a chamada paisagem conceitual.

No Brasil, a paisagem foi tema dos naturalistas e viajantes que, nos séculos XVIII e XIX, pintavam as paisagens do Novo Mundo de forma descritiva e enumerativa a fim de manter um registro dessas paisagens ainda desconhecidas para o europeu. Os holandeses trouxeram os primeiros paisagistas ao Brasil, também a Missão Francesa foi de grande importância ao retratar as paisagens brasileiras. George Grimm, do Grupo Grimm, que introduziu a pintura de paisagem ao ar livre, também fez tradição.

Antônio Parreiras, que foi aluno de George Grimm, pode ser considerado um dos primeiros paisagistas brasileiros. Ele desenvolveu uma linguagem com influência romântica, mas também realizou quadros com características mais modernas que aprendeu com seu mestre Grimm. Alguns de seus quadros contam episódios da história do Brasil (figura 3).

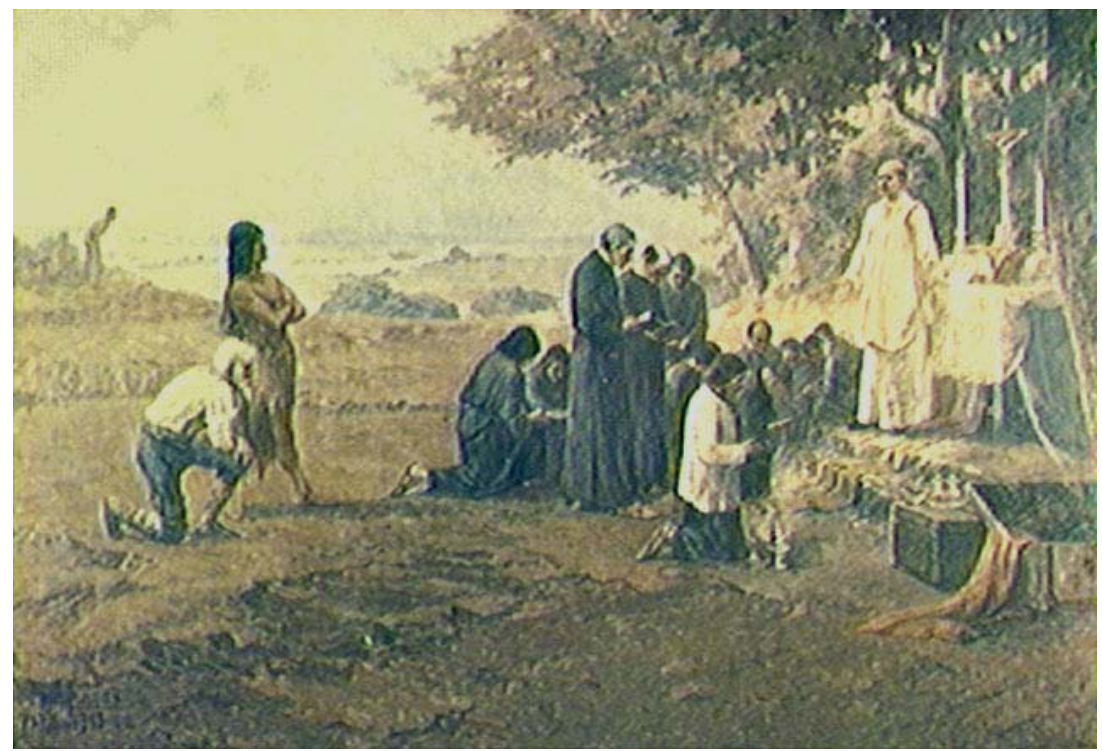

Figura 3 - Fundação da Cidade de São Paulo, 1913

Antônio Parreiras Óleo sobre Tela $-200 \times 300 \mathrm{~cm}$ Fonte: <http://www.itaucultural.org.br> Acesso: 03 fev. 2002, 16h59 
Benedito Calixto também é destaque na história da pintura de paisagem brasileira, ele pintou cenas históricas, bíblicas e paisagens do litoral paulista e por isso é mais considerado como marinhista, uma vez que a maior parte de suas paisagens são marinhas (figura 4). Devido à relativa indefinição de limites entre os diversos gêneros, "as marinhas" que são consideradas como um gênero da pintura, também podem ser identificadas como um tema ou sub-gênero da paisagem, embora Dürer (1471-1528), em fins do século $\mathrm{XV}$, não considerasse as marinhas como paisagens, pois para ele paisagem era uma porção da superfície de terra firme (BOLÓS, 1992, p. 5).

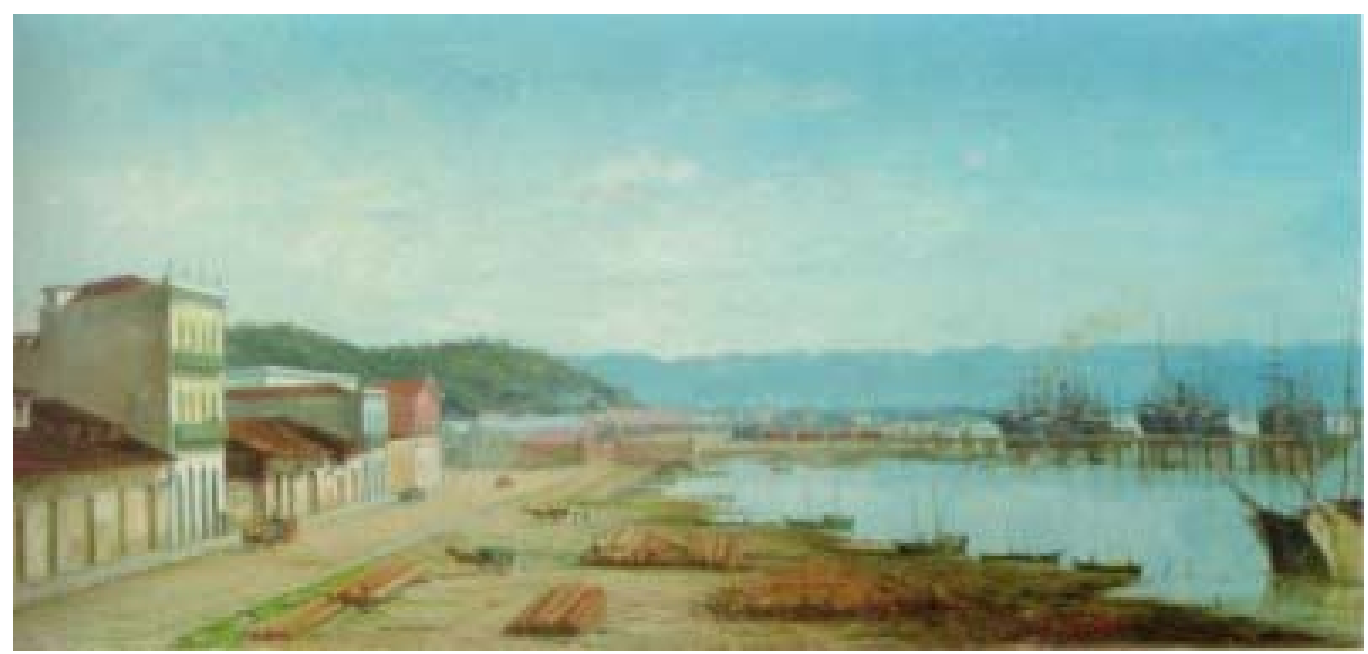

Figura 4 - Rampa do Porto do Bispo em Santos, 1900

Benedito Calixto Óleo sobre Tela $-39 \times 84 \mathrm{~cm}$ Fonte: <http://www.masp.art.br> Acesso em: 14 fev. 2002, 21h28

Após a Semana de Arte Moderna de 1922, a pintura de paisagem aparece representada nas obras de pintores do chamado Grupo Santa Helena. Aldo Bonadei, Francisco Rebolo (figura 5), Alfredo Volpi, Clóvis Graciano, Fulvio Pennacchi, Manoel Martins, Mário Zanini, Humberto Rosa e Rizzotti faziam parte desse grupo de artistas, em sua maioria imigrantes ou descendentes de imigrantes europeus, que se reuniam freqüentemente no ateliê do edifício Santa Helena, no centro de São Paulo, para trocar experiências e traçar o roteiro de suas jornadas pela cidade de São Paulo 
a fim de retratar o cotidiano, as transformações e principalmente as paisagens da cidade e arredores.

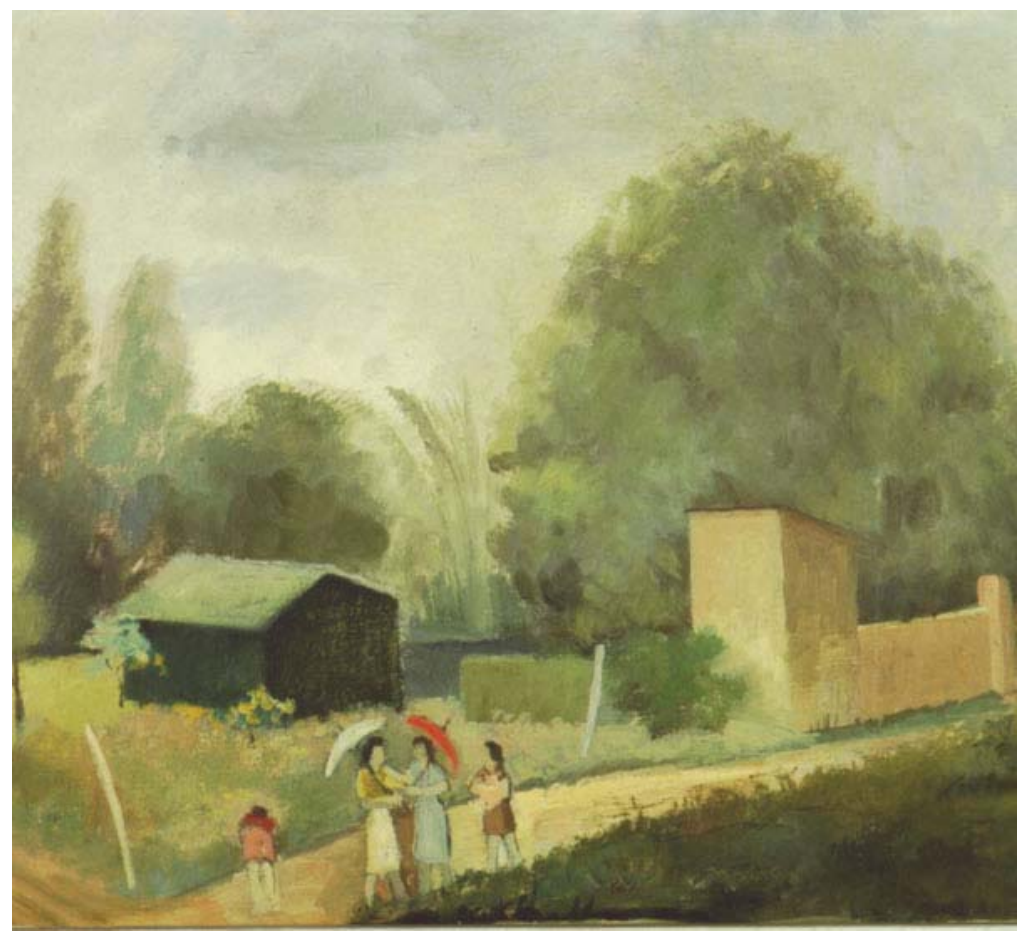

Figura 5 - Paisagem com Figuras, 1942

Francisco Rebolo

Óleo sobre Papelão - 40 x 49,7 cm - Acervo: MAC-USP

Fonte: <http://www.mac.usp.br> Acesso: 14 jul. 2002, $18 \mathrm{~h} 45$

O tema das paisagens também se manteve nas obras dos pintores da chamada Família Artística Paulista (FAP). Compunham a FAP, além de alguns nomes do Grupo Santa Helena, pintores paulistas que, apesar de terem participado das inovações da Semana de Arte Moderna, mantiveram as tradições academicistas da arte de pintar.

A maior parte desses pintores é pouco conhecida do público em geral. Apesar dos museus paulistas prestigiarem as obras de tais pintores, nas escolas a preferência quase sempre recai sobre Tarsila do Amaral, Volpi, Portinari e alguns poucos nomes, embora a pintura brasileira do século $X X$ tenha muitos e excelentes representantes em todos os gêneros. 


\section{Geografia, Arte e Percepção no Ensino: Vma}

\section{Proposta de Prática Didática}

"A arte é a representação, a ciência a explicação - da mesma realidade."

Herbert Read

O homem contemporâneo habitante dos centros urbanos está exposto a um enorme volume de imagens que estimulam sua percepção visual numa velocidade alucinante. Essas imagens produzidas pelas diversas mídias condicionam o olhar de forma que as pessoas já estão habituadas a assumirem, diante de um quadro ou das paisagens, um comportamento equivalente ao que se têm diante das imagens midiáticas.

As paisagens "passam" pelas janelas dos veículos com a mesma velocidade de um videoclip. E os quadros têm a mesma importância de um anúncio de revista. Diante das imagens, o homem contemporâneo acostumou-se a absorver o máximo que um flash permite.

Tanto as paisagens pintadas quanto as paisagens em si têm propriedades que vão além do mundo visual. Os quadros de paisagens são registros de elementos objetivos e subjetivos que revelam muito da cultura de um povo e seu tempo. As paisagens, como já foi dito, são marca e matriz de uma cultura também. 
Como afirma Berque, do ponto de vista cultural, todas as disciplinas têm a ver com o estudo da paisagem, pois importa

\begin{abstract}
[...] todos os modos de relação do indivíduo com o mundo; enfim, não é somente o indivíduo, mas tudo aquilo pelo qual a sociedade o condiciona e o supera, isto é, ela situa os indivíduos no seio de uma cultura, dando com isso um sentido à sua relação com o mundo (sentido que, naturalmente, nunca é exatamente o mesmo para cada indivíduo). (BERQUE, 1984, p. 87. In: CORRÊA \& ROSENDAHL, 1998)
\end{abstract}

Trabalhar com reproduções de quadros de pintores brasileiros é uma forma de divulgar a produção plástica brasileira, mas também uma forma de contribuir na desaceleração do olhar e da percepção para a arte (nesse trabalho restrita à pintura) promovendo uma relação estética entre o indivíduo e a paisagem do entorno, nesse caso a paisagem urbana.

Trabalhar com a paisagem geográfica a partir da arte é uma forma de desvendar a dinâmica de formação e transformação dessa paisagem e também construir um novo olhar e percepção sobre a paisagem, a fim de que o indivíduo se torne sensível à mesma.

Para Tuan (1977), conhecer e experienciar, pode ocorrer de diversas formas: de forma direta, íntima, de forma indireta e ainda de forma conceitual. A vivência direta, íntima e indireta com o objeto ou lugar proporciona uma situação de aprendizagem tanto quanto a experiência conceitual mediada por símbolos.

Um objeto ou lugar atinge realidade concreta quando nossa experiência com ele é total, isto é, através de todos os sentidos, como também com a mente ativa e reflexiva. Quando residimos por muito tempo em determinado lugar, podemos conhecê-lo intimamente, porém, a sua imagem pode não ser nítida, a menos que possamos também vê-lo de fora e pensemos em nossa experiência. A outro lugar pode faltar o peso da realidade porque 0 conhecemos apenas de fora - através dos olhos de turistas e de leitura de um guia turístico. É uma característica da espécie humana, produtora de símbolos, que seus membros possam apegar-se apaixonadamente a lugares de grande tamanho, como a nação-estado, dos quais eles só podem ter uma experiência direta limitada. (TUAN, 1977, p. 20) 
O discurso científico utiliza-se essencialmente da palavra como linguagem, mas sabemos que uma grande parcela das crianças em idade escolar apresentam dificuldade em assimilar e construir o conhecimento a partir desse referencial e que inversamente boa parte está muito mais treinada e possui familiaridade com a linguagem imagética. Isso pode ser verificado quanto à rapidez dessas crianças no aprendizado da linguagem da informática, especificamente a linguagem do windows, toda baseada em ícones.

A Geografia como ciência e a geografia como matéria do currículo escolar têm características distintas. Porém, ambas possuem a mesma intenção de conhecer e esclarecer as transformações do espaço terrestre e a ação antrópica sobre esse espaço. Ou seja, há uma preocupação com o conhecimento e para atingi-lo e construí-lo, o caminho é habitualmente o da palavra escrita, para a ciência geográfica.

Nem sempre a escola oferece aos alunos experiências de aprendizagem que estimulem o uso dos vários sentidos ao mesmo tempo, para o aprendizado de um mesmo objeto. Porém, o estudo da paisagem geográfica a partir da arte é uma oportunidade de experienciá-la a partir de outro campo de abrangência, além do conceitual. É possível considerar que a utilização de obras de arte pode modificar os vínculos afetivos com a paisagem, valorizando-a.

O sucesso do processo ensino-aprendizagem depende da conjunção de uma série de fatores que nem sempre estão ao alcance dos agentes diretamente envolvidos. Porém a escolha da linguagem a ser utilizada é prerrogativa do professor e da coordenação da escola e pode representar uma boa porcentagem de eficiência na construção do conhecimento.

Pedro Barbosa (1995, p. 39) utiliza a metáfora do Sol e de um microorganismo que só podem ser vistos através da mediação de lentes especiais adequadas para afirmar sobre a potencialidade cognitiva da arte como mediadora do conhecimento, 
do real, da verdade. Pensando nessa potencialidade da arte como mediadora do conhecimento e da imagem como linguagem, foi elaborado o roteiro de atividades apresentado nessa dissertação.

A obra de arte, no caso desse trabalho, a pintura, é um texto não-verbal, dotado de organização, sentido e coerência. Assim, a pintura é a representação do artista para a paisagem, sendo uma interpretação da realidade.

Artes, no Ensino Fundamental, atualmente é obrigatória e reconhecida nos documentos oficiais como uma das oito áreas de conhecimento que permitem atingir os objetivos gerais do Ensino Fundamental. Os Parâmetros Curriculares Nacionais de Arte considerando as dimensões da criação, da apreciação e da comunicação destacam quatro linguagens dentro das Artes - Danças, Artes Visuais, Teatro e Música - que segundo o documento podem orientar a ação dos professores de Artes.

A história do ensino de artes no Brasil mostra que nos últimos anos houve um avanço ideológico/filosófico refletido na prática pedagógica que, na maioria dos estabelecimentos de ensino rompeu com os trabalhos manuais, com o desenho geométrico e com canto orfeônico como sinônimos únicos de arte.

Sabe-se de relatos de experiências com jogos dramáticos, expressão corporal, formação de corais e desenho de criatividade, entre outras atividades, incorporadas ao cotidiano escolar que concebem a arte na escola nos moldes do que os PCNs de arte propõem: arte como linguagem e experiência sensório-cognitiva cujos eixos de aprendizagem baseiam-se no produzir, apreciar e contextualizar.

A proposta dos $\mathrm{PCNs}$ coincide, de certo modo, com a Proposta Triangular - fazer, apreciar, contextualizar - que foi introduzida no Brasil pela profa Anna Mae Barbosa e que também está explicitada no documento "Organizadores de Área - Educação Artística" da Prefeitura do Município de São Paulo. 
Porém, a realidade do ensino de artes não corresponde ao que os documentos oficiais propõem. Na prática, arte é matéria colocada em segundo plano. Em geral, as turmas têm, no máximo, dois encontros semanais com professores que não possuem formação polivalente e que acabam por se dedicar somente a uma ou duas linguagens.

Apesar da não-polivalência do professor ser uma limitação real, a arte ultrapassa barreiras e comunica de forma diferenciada das outras áreas de conhecimento. As manifestações artísticas sempre estiveram presentes na história da humanidade, em diversas linguagens. Na escola, o ensino de artes contribui à formação do indivíduo enriquecendo sua capacidade de expressão, criação, percepção, crítica, além de trabalhar a dimensão social do ser influindo na sua capacidade de inserção na sociedade e no processo de produção de conhecimento e nas atitudes.

Considerando-se que esse trabalho concorda com a Metodologia Triangular do Ensino de Arte - produzir, apreciar e contextualizar - então cabe explicitar cada um desses momentos articulando-os com o ensino de geografia, particularmente no estudo de paisagem.

Produzir, apreciar e contextualizar não acontecem necessariamente nessa ordem, nem há hierarquia única que confira legitimidade ao método. Cada um desses momentos pode se dar em ordens diversas e/ou simultâneas sem que se delimite rigidamente as etapas.

Para o "apreciar", foram escolhidos para esse projeto somente reproduções de quadros de paisagem (realizados em diferentes técnicas e materiais) de artistas brasileiros. As razões para a escolha de pintores brasileiros são valorizar e fazer conhecer a produção artística nacional e pela maior possibilidade de conhecer essas obras pessoalmente no acervo dos museus locais. 
O "apreciar" cumpriu-se a partir da leitura de reproduções impressas em papel tamanho A4. Da apreciação e leitura dessas representações houve uma articulação direta com o estudo da paisagem geográfica através da observação e identificação dos elementos objetivos da paisagem geográfica e da interpretação do artista na representação dessa paisagem.

A apreciação e leitura da obra de arte pedem a "contextualização" da mesma, que ocorreu paralelamente à análise do processo de construção e transformação da paisagem geográfica no tempo, uma ferramenta que permite o contato do indivíduo com sua cultura e com a cultura do outro e de outro tempo.

O "produzir" artístico, nesse trabalho circunscrito à linguagem plástica, é o momento de expressão do aluno através do desenho e da pintura, onde ele externaliza sua percepção da paisagem em dois momentos da atividade, com liberdade de estilo, embora com limitação de materiais.

Trabalhar com as representações da paisagem in loco e com as representações dos artistas, é oferecer a oportunidade de trabalhar com as formas perceptivas e reflexivas de representação da paisagem, ampliando as possibilidades de abrangência e aprendizagem.

De acordo com FORGUS (1966, p. 3) "[...] a percepção pode ser definida como o processo pelo qual um organismo recebe ou extrai certas informações acerca do ambiente." Extrair informações do ambiente é parte essencial do processo ensinoaprendizagem. Se o objetivo é construir o conhecimento sobre a paisagem, as informações obtidas diretamente do ambiente são parte da matéria essencial desse conhecimento.

Quanto maior for a capacidade de extrair essas informações tanto maior o repertório e portanto amplia-se também a potencialidade de capacidade de relacionar e pensar criticamente sobre a paisagem. Segundo FORGUS (1966, p. 3), “[...] à medida que o 
conjunto perceptivo vai sendo ampliado, tornando-se mais complexo e rico de padrões, através da experiência, mais capaz se torna o indivíduo de extrair informação do ambiente." Se entendermos o ambiente como o conjunto de informações potencialmente disponíveis, incluindo-se aí a paisagem geográfica e as paisagens representadas só resta oferecermos aos alunos instrumentos que os auxiliem a extrair essas informações e ampliar suas percepções sobre as paisagens. 


\title{
5 Roteiro de Atividades: A Realização do
}

\section{Experimento}

\author{
"A verdadeira educação e a verdadeira aprendizagem \\ fundem todas as disciplinas em uma apreensão global \\ para a qual a aprendizagem de si é tão importante \\ quanto o conhecimento do mundo. Um conhecimento de \\ si que finalmente nos leva a perceber que somos, todos \\ juntos, uma consciência iluminando um mundo."
}

Pierre Lévy

No intuito de verificar a viabilidade do estudo da paisagem geográfica articulado com arte, os experimentos em sala de aula com alunos foram divididos em duas etapas. $\mathrm{Na}$ primeira etapa, um roteiro de atividades foi elaborado e desenvolvido sucessivamente com três grupos de alunos com perfis diferentes, de escolas diferentes, identificadas pelos números 1,2 e $3^{12}$. Esse roteiro foi desenvolvido nas três escolas de formas diferenciadas quanto à distribuição do tempo, características e organização das atividades, o que resultou em contínuas adaptações até o formato final do roteiro de atividades. Todo o trabalho de aplicação das atividades didáticas da primeira etapa foi realizado pessoalmente por mim com a participação dos professores das turmas como observadores e auxiliares.

Na segunda etapa, o roteiro final (Apêndice $A$ ) definido durante a primeira etapa a partir da observação e avaliação contínuas do trabalho, foi minuciosamente

\footnotetext{
${ }^{12}$ As identidades das escolas foram preservadas de acordo com o que foi acordado entre todas as partes durante os trabalhos de campo.
} 
explicado e apresentado a um grupo de 38 professores durante a Oficina denominada Paisagem, Arte e Geografia no Departamento de Geografia na Faculdade de Filosofia, Letras e Ciências Humanas da Universidade de São Paulo, na qual esses professores foram orientados e convidados a aplicar as atividades com seus alunos mediante acompanhamento à distância. Desses 38 professores, um grupo de sete professores pertencentes a cinco instituições (escolas 4, 5, 6, ONG 1 e ONG 2) desenvolveu o roteiro de atividades proposto. As etapas de elaboração, organização e realização do trabalho estão descritas a seguir.

\subsection{Organização e Elaboração do Roteiro de Atividades}

A princípio foi elaborado um roteiro com 10 atividades, idealizado de forma a contemplar momentos de estudo da paisagem geográfica, com destaque para a paisagem urbana da cidade de São Paulo, e momentos de produção, apreciação e contextualização em arte, especificamente com quadros de paisagem de pintores brasileiros.

Após a primeira realização prática do roteiro de atividades com alunos de uma $6^{a}$ série-supletivo da escola 1, verificou-se a necessidade de ajuste e redistribuição de carga horária, supressão e modificação de atividades, bem como inclusão de outras atividades. Das dez atividades iniciais, algumas foram modificadas, outras preservadas e outras incluídas no roteiro adaptado aplicado nas escolas 2 e 3 . A experiência realizada nessas últimas escolas demonstrou a necessidade de pouca modificação para o roteiro final.

Esse roteiro final (Quadro 1) foi definido a partir da experiência na primeira etapa da pesquisa de campo e é o roteiro que foi entregue ao grupo de professores que participaram da Oficina que se constitui na segunda parte dos experimentos dessa pesquisa. 


\begin{tabular}{|c|c|}
\hline Atividades & Procedimentos \\
\hline $\begin{array}{l}\text { A - Desenhando e pintando a } \\
\text { vista da janela }\end{array}$ & Desenho de observação da vista da janela. \\
\hline $\begin{array}{l}\text { B - Diagnóstico de paisagem e } \\
\text { seus elementos }\end{array}$ & Alunos respondem individualmente a 5 questões sobre paisagem. \\
\hline $\mathrm{C}$ - O que é paisagem? & $\begin{array}{c}\text { Discussão dirigida e apresentação de três reproduções de } \\
\text { paisagens, duas urbanas e uma rural. }\end{array}$ \\
\hline $\begin{array}{l}\text { D - Paisagem e uso do solo: } \\
\text { leitura gráfica }\end{array}$ & Confecção de overlays sobre quadros 2 e 3. \\
\hline $\begin{array}{l}\text { E - Paisagem e uso do solo: } \\
\text { urbano e rural }\end{array}$ & $\begin{array}{c}\text { Discussão dirigida e interpretação dos overlays, com ênfase na } \\
\text { diferença entre rural e urbano. }\end{array}$ \\
\hline F - Por que a paisagem muda? & $\begin{array}{c}\text { Exercícios escritos em grupos com observação dos quadros } 1 \text { e } \\
2 .\end{array}$ \\
\hline $\begin{array}{l}\text { G - Novo olhar sobre o desenho e } \\
\text { a pintura }\end{array}$ & $\begin{array}{c}\text { Exposição sobre gêneros na pintura e procedimentos para o } \\
\text { desenho de paisagem. }\end{array}$ \\
\hline H - Novo olhar sobre a paisagem & Desenho de observação sobre a paisagem da janela. \\
\hline I - Avaliação Final & $\begin{array}{l}\text { Alunos avaliam individualmente, por escrito, o conjunto de } \\
\text { atividades. }\end{array}$ \\
\hline
\end{tabular}

\section{Quadro 1 - Síntese das Atividades do Roteiro Final}

O quadro 1 demonstra resumidamente as nove atividades que constituem o roteiro final e serve de orientação, juntamente com o apêndice $A$, para a compreensão da descrição do processo de elaboração do roteiro e das etapas de preparação e organização do material utilizado.

\subsubsection{Os Quadros: OChares sobre São Paulo}

Para a elaboração do roteiro de atividades foram coletadas mais de 180 reproduções de quadros de paisagens de 40 pintores brasileiros, em livros, catálogos de exposição e, principalmente, na Internet. Dessas imagens, inicialmente foram selecionados 12 quadros de 7 artistas para serem utilizados nas atividades do roteiro que foi aplicado na escola 1.

Todos os 12 quadros selecionados são de paisagens da cidade da São Paulo ou referentes ao ambiente urbano. Portanto, a escolha dos artistas esteve muito mais relacionada ao conteúdo dos quadros do que ao conjunto da obra ou notoriedade do 
pintor. A princípio havia uma preferência por pintores mais conhecidos do público em geral e cujos quadros fizessem parte do acervo de museus estabelecidos na capital paulista. Porém, durante a pesquisa notou-se que nem sempre as paisagens pintadas e mais adequadas ao trabalho proposto estavam disponíveis à visitação em museus, mas sim faziam parte de acervos particulares ou não havia informação sobre a localização da obra, o que tornou inviável esse critério de escolha.

Os artistas escolhidos para esse trabalho são todos nascidos ou naturalizados brasileiros e que têm sua obra produzida, principalmente, no século XX. Dentre as técnicas e materiais dos trabalhos selecionados há uma grande variedade - desde pintura a óleo, xilogravuras, aquarelas, acrílica, pastel, etc. - que se traduz também na variedade de estilos, embora todas as obras selecionadas sejam figurativas.

A preferência pela figuração em detrimento das representações abstratas deu-se principalmente pela materialização e identificação das formas nas pinturas figurativas, que melhor se adaptam ao objetivo do conjunto de atividades propostas.

Com facilidade descobrimos e aceitamos o fato de um objeto visual no papel representar um completamente diferente da natureza, desde que nos seja apresentado em seu equivalente estrutural para o meio dado.

A razão psicológica deste fenômeno surpreendente é, primeiro, que, na percepção e pensamento humanos, a semelhança baseia-se não numa identidade meticulosa, mas na correspondência das características estruturais essenciais; segundo, que uma mente pura entende espontaneamente qualquer objeto dado conforme as leis do seu contexto. (ARNHEIM, 1954, p. 131)

Como o objetivo dessa pesquisa esteve mais voltado para os aspectos objetivos da representação da paisagem em arte como ponto de partida para realizar a exploração das representações e significados da paisagem geográfica, as pinturas figurativas conservam as características estruturais das paisagens necessárias às reflexões propostas.

Quanto aos materiais utilizados nas pinturas, houve uma tentativa de manter um mínimo de homogeneidade na escolha dos quadros. Como não foi possível combinar 
quadros com utilização de uma só técnica na seleção das pinturas, optou-se por manter a menor variedade possível entre eles, a fim de que não houvesse um excesso de informações a serem discutidas durante as atividades.

Inicialmente foram selecionados dois quadros da cidade de São Paulo, dentre aqueles 12, que representam paisagens de épocas diferentes: Aspectos de São Paulo (figura 6) de 1942 de Antônio Gomide e Teatro Municipal (figura 7) de 1985 de Agostinho Batista de Freitas, que foram denominados de quadros 1 e 2 respectivamente, nos exercícios e atividades propostas.

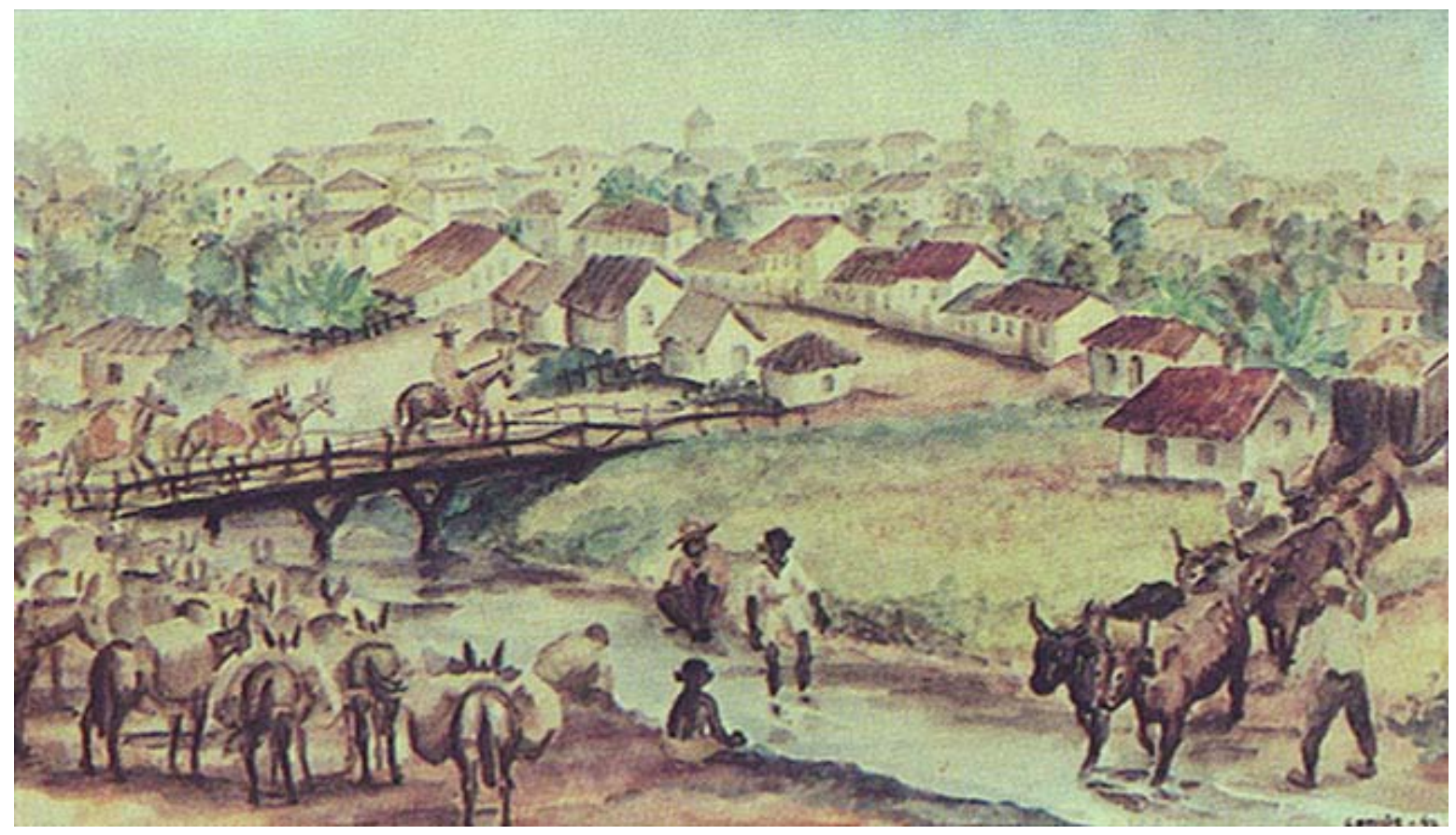

Figura 6 - Aspectos de São Paulo, 1942

Antônio Gomide Aquarela sobre Papel - s/ inf. Fonte: <http://www.itaucultural.org.br> Acesso: 02 nov 2001, 15h09 


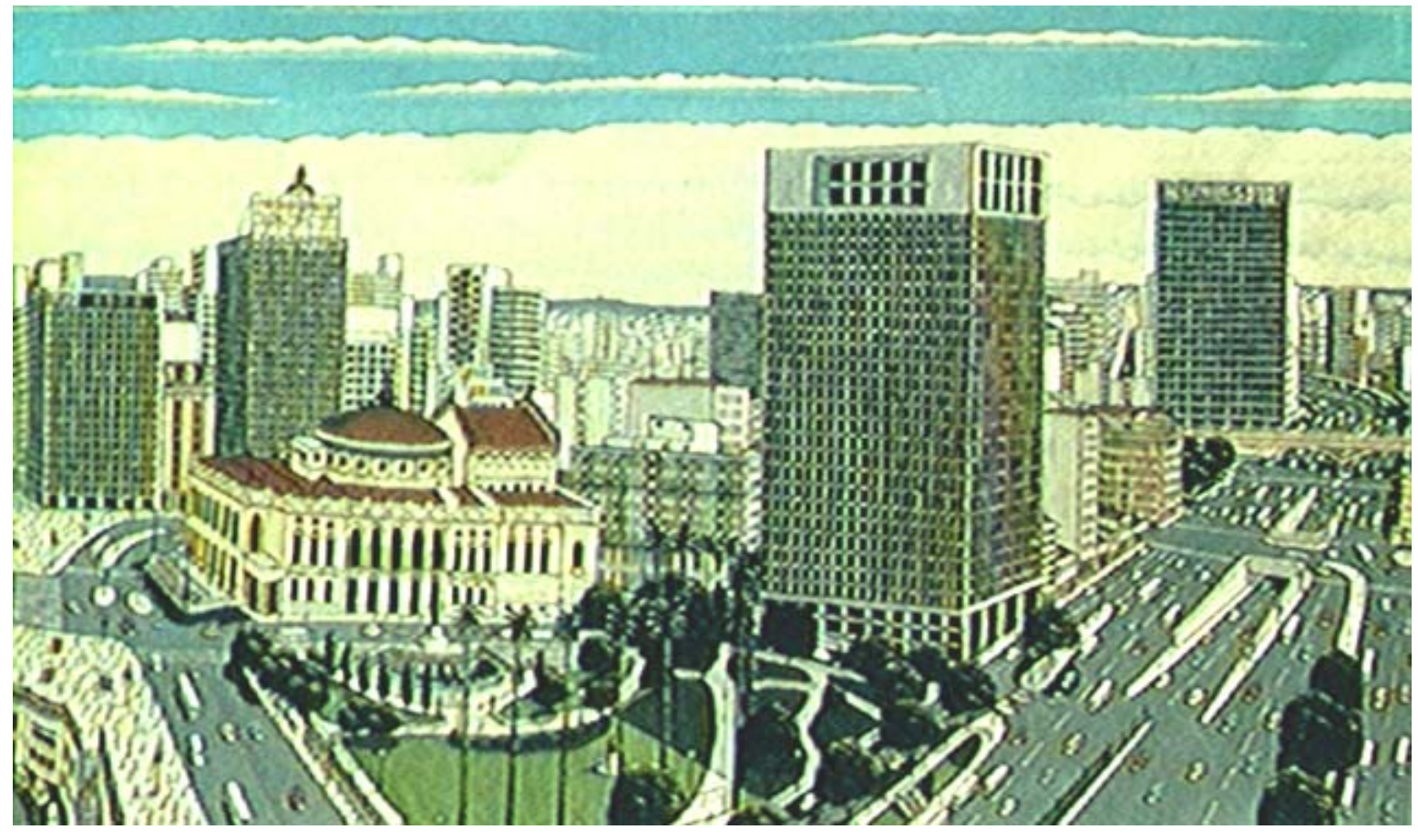

Figura 7 - Teatro Municipal, 1985

Agostinho Batista de Freitas Óleo sobre Tela $-80 \times 140 \mathrm{~cm}$

Fonte: <http://www.itaucultural.org.br> Acesso em: 13 abr. 2002, $16 \mathrm{~h} 18$

Esses dois quadros foram selecionados para serem a base do estudo de paisagem urbana, pois representam a cidade de São Paulo em datas diferentes, a década de 40 e a década de 80 , e permitem uma comparação das transformações da paisagem da cidade, mudanças na forma, na estrutura e na função.

Do ponto de vista da forma em arte, são dois quadros com técnicas diferentes, aquarela sobre papel em Aspectos de São Paulo e óleo sobre tela em Teatro Municipal e que possibilitam um debate sobre a importância do material nos efeitos das representações. Também a diferença na formação de cada pintor teve relevância na escolha e permitiu durante as atividades com alunos uma discussão em torno da importância da dedicação e do estudo da arte.

Antônio Gomide (1895-1967) freqüentou ateliês de pintores famosos como Picasso e escolas de arte no Brasil e na Europa, principalmente na França. Sua obra traz 
experimentos em vários estilos e materiais, é comum a denominação de pintor acadêmico ser atribuída a Gomide. Agostinho Batista de Freitas (1927-1997) era eletricista e artista autodidata, conhecido como pintor naïf, que nas horas vagas se ocupava pintando quadros nas ruas do centro da cidade, tornou-se pintor famoso principalmente por intermédio de Pietro Maria Bardi que o descobriu, por acaso, vendo-o pintar a cidade de São Paulo instalado na Praça do Correio.

Contrapor a obra de dois pintores com formações tão diversas, trouxe à discussão a questão do preconceito de que a arte é matéria restrita a quem aprende a desenhar e pintar ou que "nasce sabendo". Em todas as turmas houve a reação inicial de alguns alunos que se diziam inibidos para desenhar e pintar pois não sabiam fazê-lo. Mostrar a eles o quadro de um pintor que nunca havia freqüentado uma escola de artes, fez com que se sentissem mais seguros para experimentar.

Diante da dificuldade de encontrar duas representações da mesma paisagem em épocas diferentes, a escolha desses dois quadros recaiu principalmente sobre o critério de semelhança no enquadramento e na distribuição de alguns elementos básicos. Ambos apresentam, no conteúdo, aspectos da urbanidade de São Paulo em datas distintas, identificam claramente características da organização do espaço urbano, as vias de circulação e os meios de transportes, o adensamento e a verticalização, a retificação e canalização de rios como parte dos elementos objetivos que podem ser observados nos quadros e que são indispensáveis à percepção e ao estudo da paisagem.

O conteúdo dos quadros é o registro da paisagem que permite objetivamente identificar alguns elementos de suporte e cobertura da paisagem geográfica bem como avaliar minimamente a evolução ou transformações das relações e da atuação do homem como ser cultural nessa paisagem.

A observação da forma nessas reproduções, em termos de paisagem como gênero da pintura, permite avançar na percepção da construção e transformação da 
paisagem e suas representações: as tonalidades das cores utilizadas, as diferenças nas escalas, no estilo, as técnicas e materiais utilizados, são todos elementos que evidenciam a objetividade e subjetividade do olhar sobre a paisagem.

O roteiro realizado na escola 1 previa um conjunto de atividades baseadas nos quadros Aspectos de São Paulo e Teatro Municipal. Porém, no momento das discussões sobre paisagens urbanas e rurais, o quadro Aspectos de São Paulo revelou dúvidas e dificuldades dos alunos, que baseados na simples enumeração dos elementos da paisagem e sem a análise da função desses elementos, concluiu erroneamente que se tratava de uma paisagem rural e não de uma paisagem urbana da década de 1940.

Nesse momento ficou clara a necessidade de contrapor ao quadro Aspectos de São Paulo uma paisagem rural para que a discussão não ficasse na superficialidade. Assim, o roteiro de atividades foi adaptado para as escolas 2 e 3 e foi inserido o estudo do quadro Paisagem com Animais, um óleo sobre tela de Antônio Gomide sem data, identificado como quadro n 3 nos exercícios.

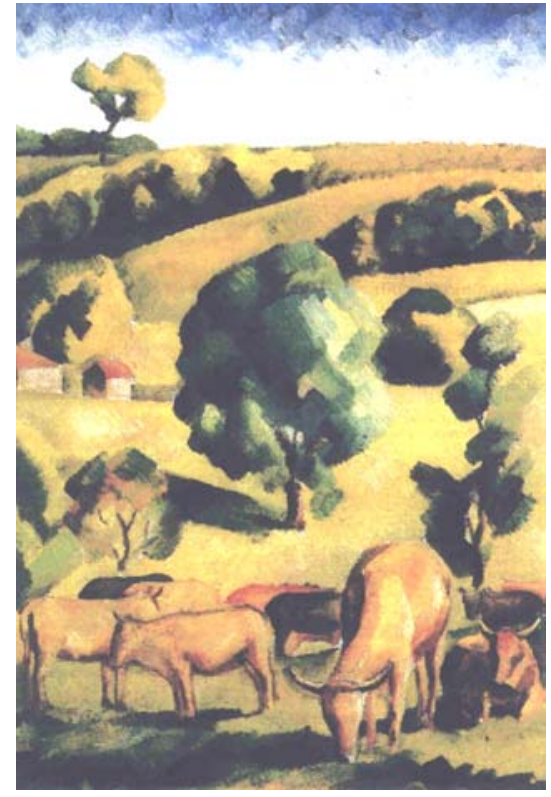

Figura 8 - Paisagem com Animais Antônio Gomide

Óleo sobre Tela, s/ ass. $-45,0 \times 30,5 \mathrm{~cm}$

Fonte: Catálogo de Exposição: Antônio Gomide - Quatro Décadas de Modernidade 
O quadro Paisagem com Animais é uma típica paisagem de área de pastagem com pequenas manchas de mata e árvores isoladas pontuando extensos pastos, onde aparecem apenas algumas cabeças de gado em primeiro plano e no centro à esquerda duas pequenas construções isoladas. Ou seja, uma paisagem rural que permite a identificação de uma atividade primária que a caracteriza e que colocada ao lado do quadro 1 trouxe reflexões importantes sobre as funções das paisagens.

Com base na idéia de que a identidade de algo também é construída a partir da comparação com o seu diferente, a inclusão do quadro Paisagem com Animais facilitou a discussão sobre funções das paisagens, a relação entre os elementos de uma paisagem e o homem como um desses elementos e agente modificador.

Os outros dez quadros (figuras 9 a 18) selecionados para a atividade $A$ paisagem geográfica na paisagem pintada (ver atividade complementar 2 - Apêndice C) aplicada na escola 1, foram suprimidos nas escolas seguintes 2 e 3 juntamente com os dois textos e inseridos como atividade complementar 2 para o roteiro final. Um dos motivos para a supressão dos quadros foi a constatação da falta de intimidade dos alunos com a linguagem plástica, o que demandaria a ampliação do tempo dedicado à atividade.

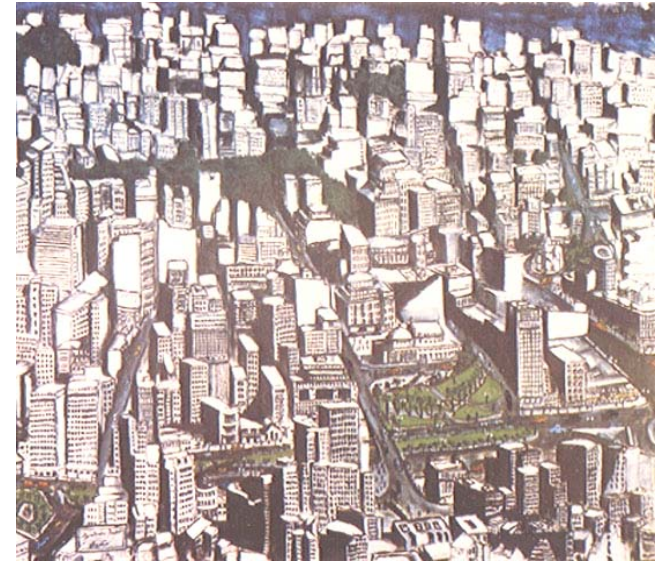

Figura 9 - Vista de São Paulo, 1952

Agostinho Batista de Freitas Óleo sobre Tela $-80 \times 100 \mathrm{~cm}$

Fonte: <http://www.itaucultural.org.br> Acesso: 13/abr/2002, $16 \mathrm{~h} 18$

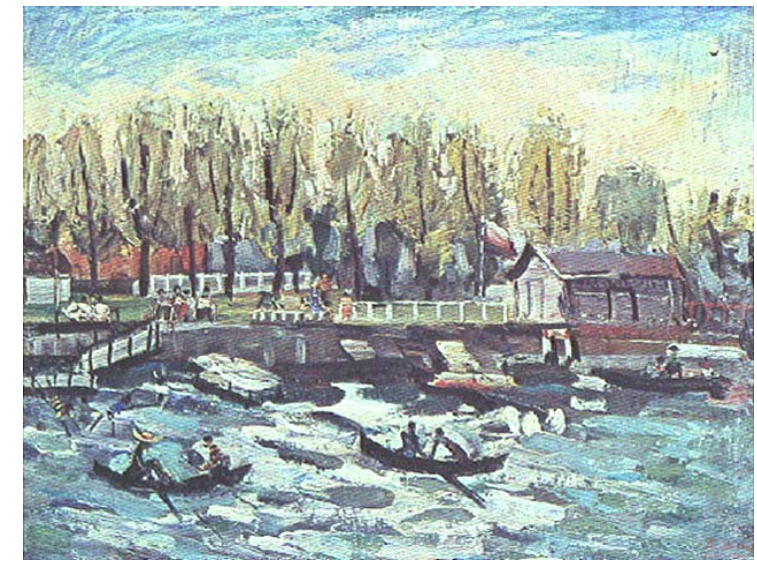

Figura 10 - Tietê, 1940

Mário Zanini

Óleo sobre Tela - 33,5 x 46cm

Fonte: <http://www.itaucultural.org.br> Acesso: 07/abr/2002, 21h29 


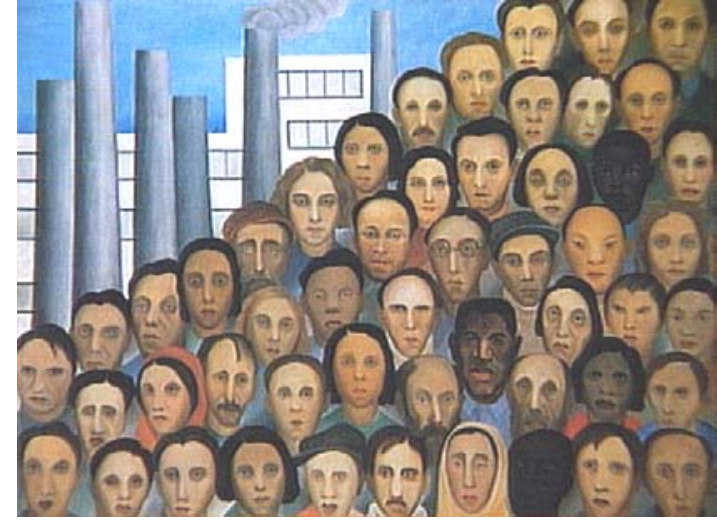

Figura 11 - Operários, 1933

Tarsila do Amaral

Óleo sobre Tela - $150 \times 230 \mathrm{~cm}$

Acervo: Palácio Boa Vista (Campos do Jordão-SP) Fonte: <http://www.itaucultural.org.br>

Acesso: 02/nov/2001, 13h11

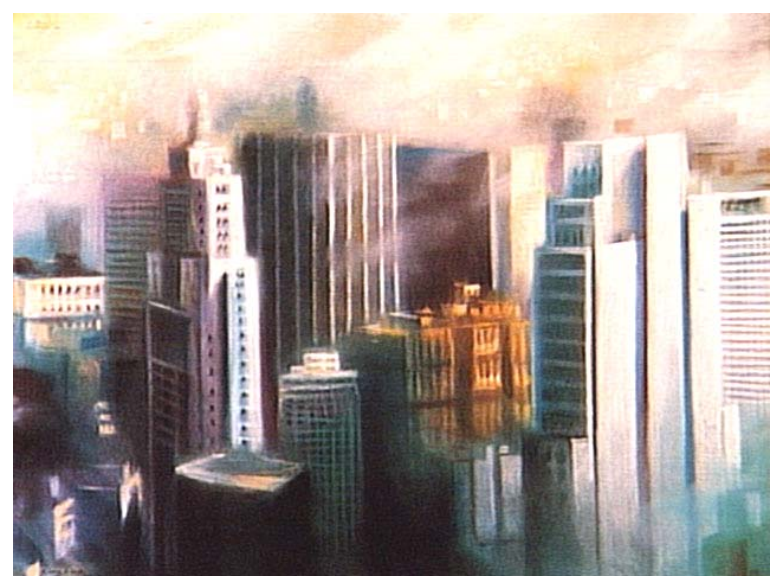

Figura 13 - Banco Despertando a Cidade, 1988

Gregório Gruber

Pastel $-70 \times 100 \mathrm{~cm}$

Fonte: <http://www.itaucultural.org.br>

Acesso: 03/fev/2002, 18h28

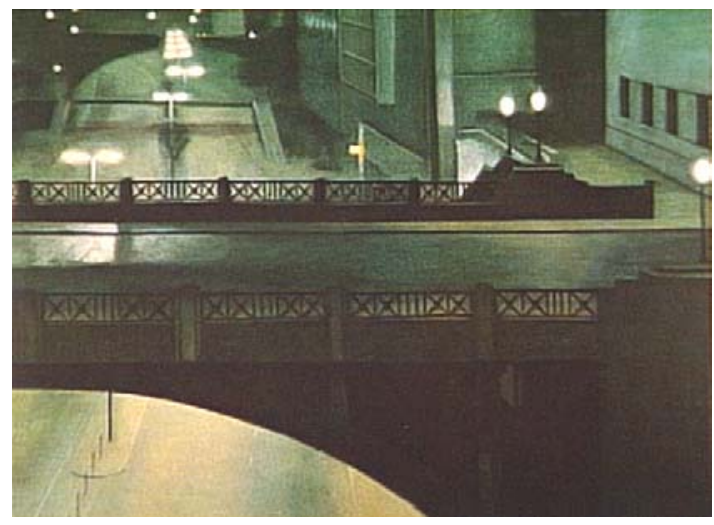

Figura 12 - Viaduto à Noite, 1980

Gregório Gruber

Óleo sobre Tela - $100 \times 140 \mathrm{~cm}$

Fonte: <http://www.itaucultural.org.br> Acesso: 03/fev/2002, 18h11

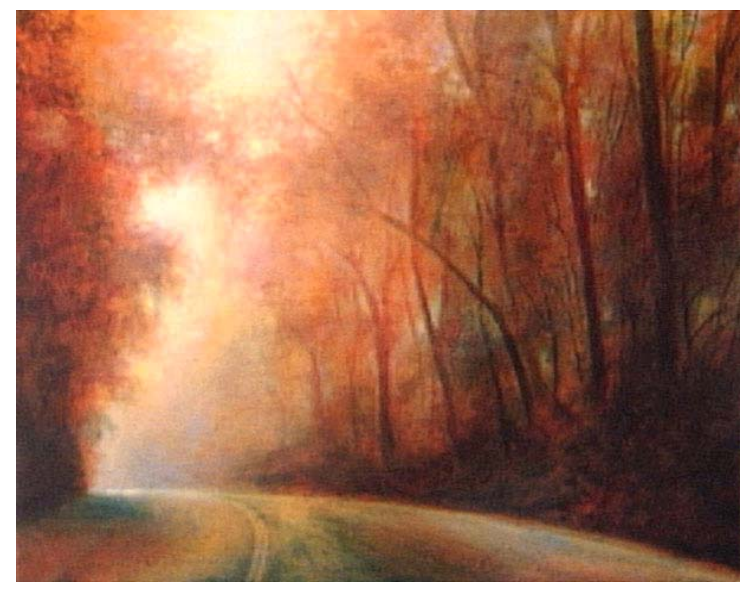

Figura 14 - Cantareira, 1988

Gregório Gruber

Óleo sobre Tela - $100 \times 140 \mathrm{~cm}$

Fonte: <http://www.itaucultural.org.br> Acesso: 03/fev/2002, 18h20 


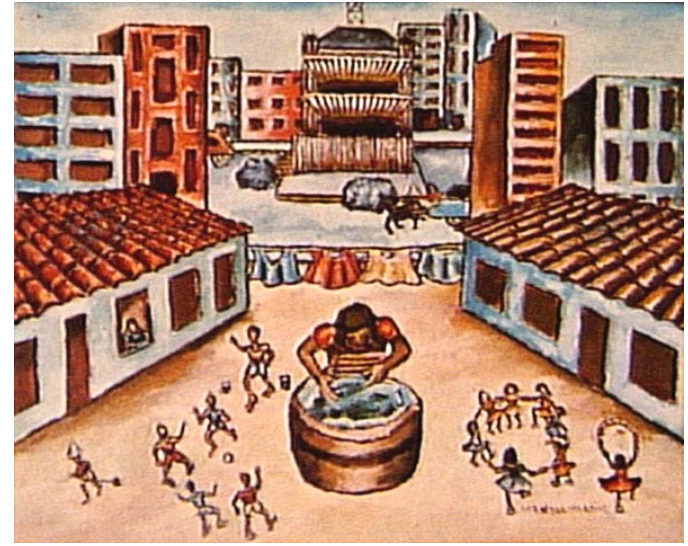

Figura 15 - Vista da Vila, s.d.

Manoel Martins

Óleo sobre Tela, $40 \times 60 \mathrm{~cm}$

Fonte: <http://www.itaucultural.org.br>

Acesso: 07/abr/2002, 21h14

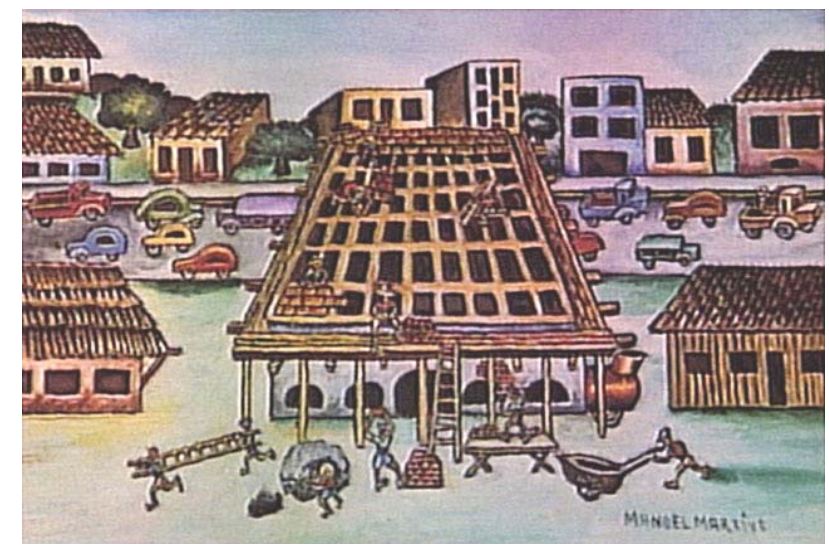

Figura 16 - Construção, 1979

Manoel Martins

Óleo sobre Tela, $40 \times 60 \mathrm{~cm}$

Fonte: <http://www.itaucultural.org.br>

Acesso: 07/abr/2002, 21h10

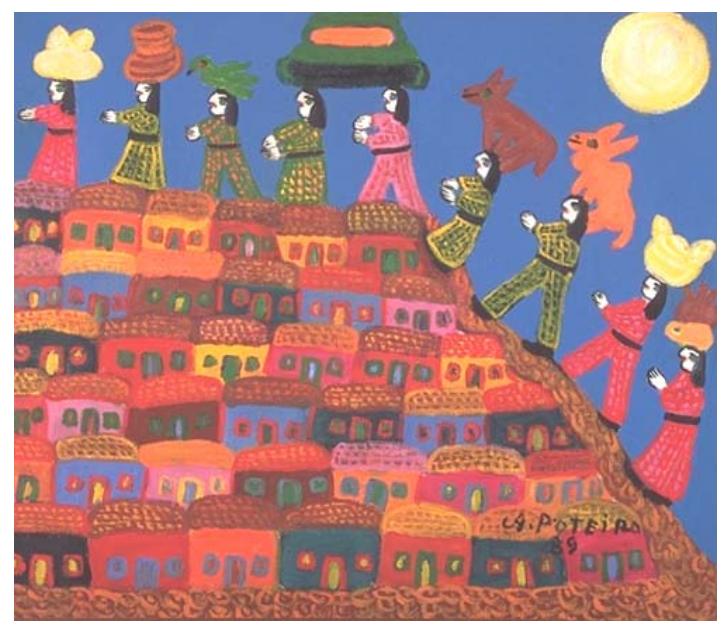

Figura 17 - Os Retirantes

Antônio Poteiro

sem informação

Fonte: <http://www.rancholapuerta.com> Acesso: 14/set/2002, 17h24

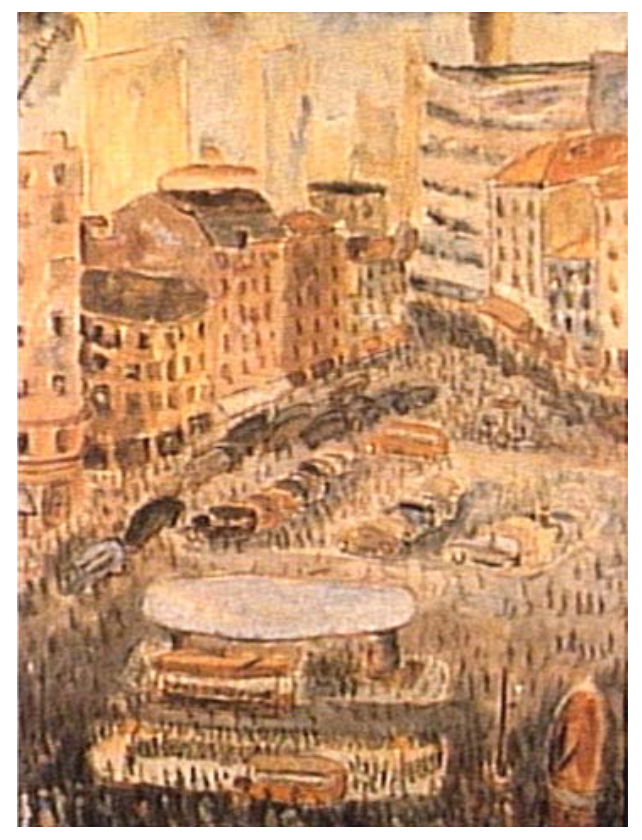

Figura 18 - Praça da Sé, 1940

Manoel Martins

Óleo sobre Madeira - $50 \times 40 \mathrm{~cm}$

Fonte: <http://www.itaucultural.org.br> Acesso: 07/abr/2002, 21h12 
Cada um quadros foi selecionado com o intuito de abordar algumas características da cidade de São Paulo ou de um grande centro urbano: a transformação e ocupação das margens dos rios e a poluição dos mesmos (figura 10); a predominância das atividades dos setores secundários e terciários e a composição da população (figura 11); as migrações (figura 17); o centro da cidade, a iluminação artificial e o esvaziamento das áreas centrais comerciais à noite (figura 12); a verticalização e a poluição atmosférica e sonora (figura 13); a ausência e a presença de áreas verdes e de lazer nos centros urbanos (figura 14); os contrastes da cidade na arquitetura e nas relações sociais (figura 15); as construções e a velocidade de transformação da cidade (figura 16); a organização e o caos urbano (figuras 9 e 18).

Tendo em vista as dificuldades apresentadas pelos alunos em combinar leitura de textos com leitura de quadros e em razão da dificuldade para estender as atividades por mais dias, optou-se por suprimir a atividade $A$ paisagem geográfica na paisagem pintada, que utilizava esses dez quadros e inseri-la no roteiro final como sugestão de atividade extra (ver atividade complementar 2 - Apêndice $C$ ), uma vez que a atividade é uma oportunidade de discussão sobre outras formas de perceber e representar da cidade de São Paulo.

Além dos três quadros selecionados para a proposta de trabalho sobre a percepção e conceito de paisagem, nas atividades desenvolvidas nas escolas 2 e 3 e no roteiro final foram incluídos outros seis quadros, no intuito de ilustrar uma explanação sobre gêneros na pintura. Esses quadros foram incluídos para exemplificar os seguintes gêneros: marinha com o quadro Ubatuba de Francisco Rebolo (figura 19), abstrato com o quadro Abstrato de Alfredo Volpi (figura 21), nu com o quadro Nu Feminino de Antônio Gomide (figura 20), natureza-morta com o quadro Natureza-morta de Cândido Portinari (figura 22), retrato com o quadro Retrato de Carlos Drummond de Andrade de Cândido Portinari (figura 23) e auto-retrato com o quadro Auto-retrato de Antônio Gomide (figura 24). 


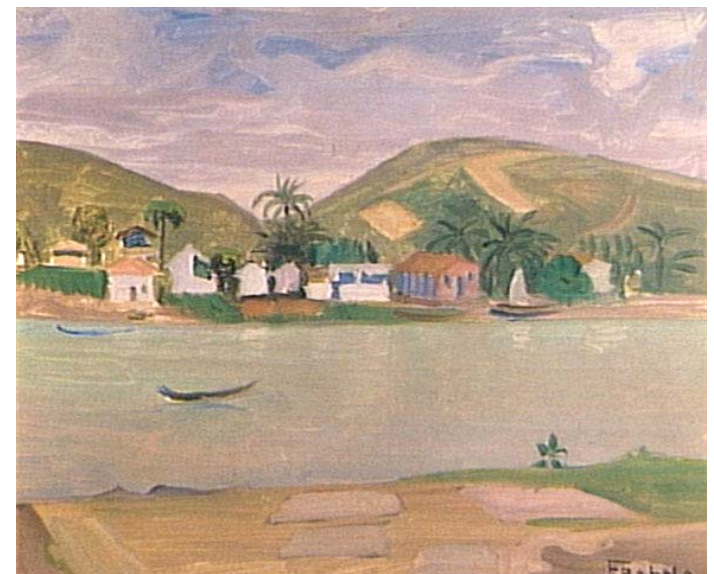

Figura 19 - Ubatuba, 1968

Francisco Rebolo

Óleo sobre Hardboard - $33 \times 41 \mathrm{~cm}$

Fonte: <http://www.itaucultural.org.br>

Acesso: 03/fev/2002, 18h00

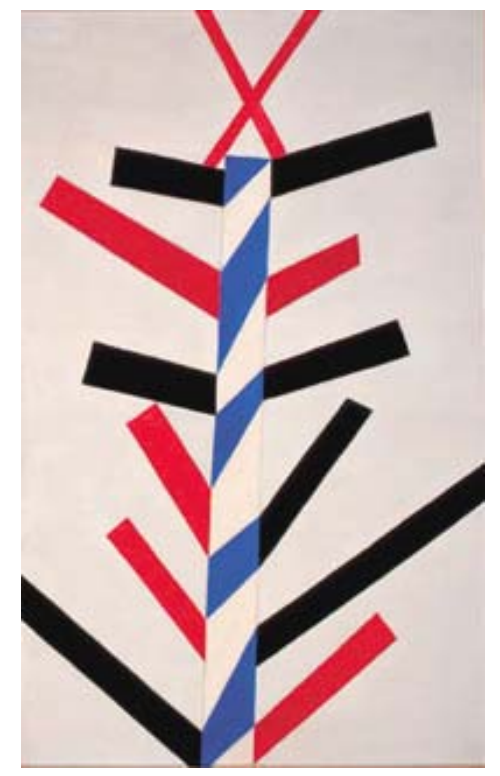

Figura 21 - Abstrato, 1957

Alfredo Volpi

Óleo sobre Tela - $165 \times 102 \mathrm{~cm}$

Coleção: Museu de Arte Brasileira - FAAP

Fonte: <http://www.faap.bf/museu/acervo>

Acesso: 02/set/2002, 12h44

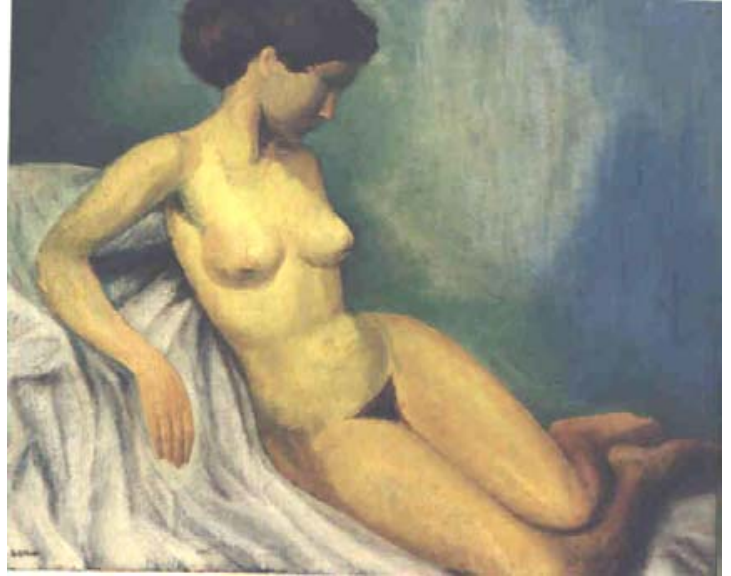

Figura 20 - Nú, s.d

Antônio Gomide

Óleo sobre Tela - 59,5 x 72,5cm

Fonte: Catálogo de Exposição: Quatro de Modernidade

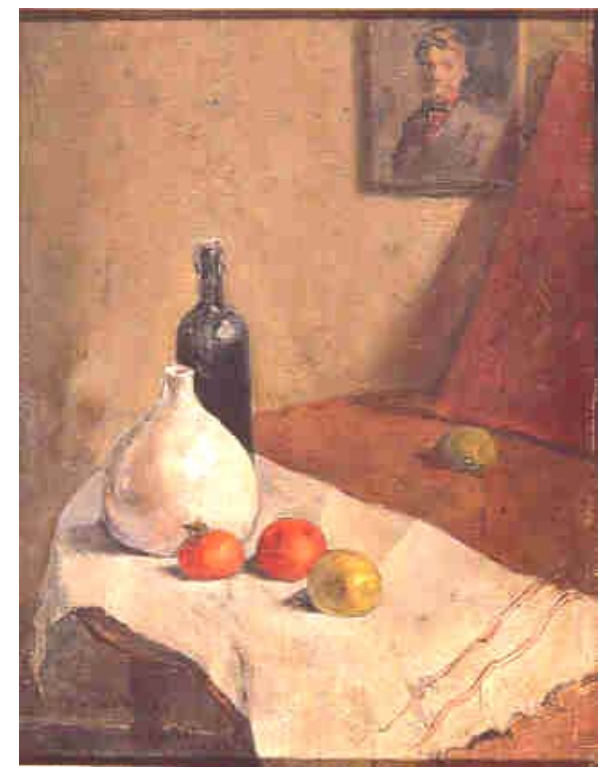

Figura 22 - Natureza-morta, 1930

Cândido Portinari

Óleo sobre Madeira Compensada - 35 x 26,5cm

Coleção Particular

Fonte: <http://www.portinari.org.br>

Acesso: 31/mar/2003, 22h36 


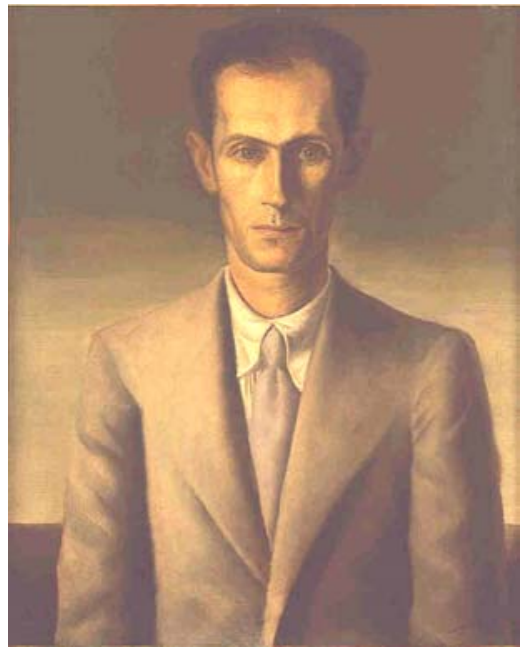

Figura 23 - Retrato de Carlos

Drummond de Andrade, 1936

Cândido Portinari

Óleo sobre Tela - 72 × $58 \mathrm{~cm}$

Coleção Particular

Fonte: <http://www.portinari.org.br>

Acesso: 02/set/2002, 23h38

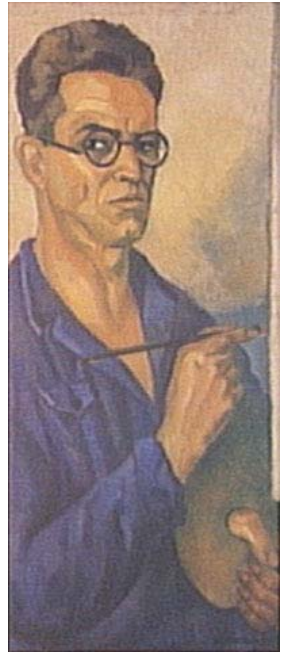

Figura 24 - Auto-retrato, 1930

Antônio Gomide

Óleo sobre Tela - 106 x 49cm

Acervo: MAC-USP

Fonte: <http://www.itaucultural.org.br>

Acesso: 02/nov/2001, 15h05

No caso dessas reproduções, elas foram utilizadas somente para observação dos alunos e nenhuma outra proposta de leitura dessas obras foi realizada. Nem mesmo houve a intenção de esgotar a discussão sobre gêneros na pintura. O intuito foi somente de ilustrar a explicação, e ainda assim houve a preocupação em trazer reproduções de pintores brasileiros e todas pinturas a óleo, a fim de não diversificar e ampliar demais as possibilidades de discussão, já que o tempo era restrito.

Todos as reproduções foram impressas em cores sobre papel branco tamanho A4 de $180 \mathrm{~g}$ e protegidos com uma capa plástica transparente. No anverso da folha, a impressão em cores teve tamanho máximo possível e no verso da folha foram registrados os dados referentes ao quadro, com autor, título, data, técnica, tamanho, acervo em que se encontra a obra e fonte da figura (modelo no anexo B). 


\subsubsection{O Material Vtilizado: Instrumentos de Expressão}

A proposta do roteiro de atividades inicia-se com os alunos fazendo o desenho da vista da janela da sala de aula (ou equivalente) em papel sulfite A4 e giz de cera. A escolha desse material está relacionada a dois aspectos. Primeiro, em razão de que o material utilizado condiciona o olhar e a intenção de representação.

\footnotetext{
O artista, é claro, pode transmitir só o que o seu instrumento e veículo são capazes de executar. Sua técnica restringe sua liberdade de escolha. As características e relações que o lápis é capaz de captar diferem das que o pincel reproduz. Sentado diante do seu motivo, com o lápis na mão, o artista procura, então, aqueles aspectos que pode representar em linhas - como costumamos dizer, numa abreviação desculpável, ele tende a ver o seu motivo em termos de linhas, ao passo que, com pincel na mão, ele vê em termos de massas. (GOMBRICH, 1959, p. 69)
}

Assim, o giz de cera não condiciona à representação de linhas da mesma forma que um lápis e nem restringe o desenho em termos de massas como o pincel. $\mathrm{O}$ giz de cera traz em si as duas possibilidades de representação de acordo com a forma de preparação e manipulação do material (se apontado, quebrado em pedaços ou não).

Embora não tenha sido prevista nenhuma discussão aprofundada sobre a diferença entre desenho e pintura junto com os alunos, a utilização do giz de cera possibilitou pintar a paisagem e não só desenhá-la. A pintura amplia a capacidade de expressão e pode ainda disfarçar as limitações técnicas do desenho. Segundo Nélson Brissac Peixoto, a pintura apresenta vantagens sobre o desenho, pois "no desenho, a paisagem nos escapa, como se estivéssemos sentados de costas num trem. Na tela colorida a direção se inverte: a paisagem vem em nossa direção, revelada pela graça da luz, que o corte abrupto do traço ignora" (1996, p. 29). 


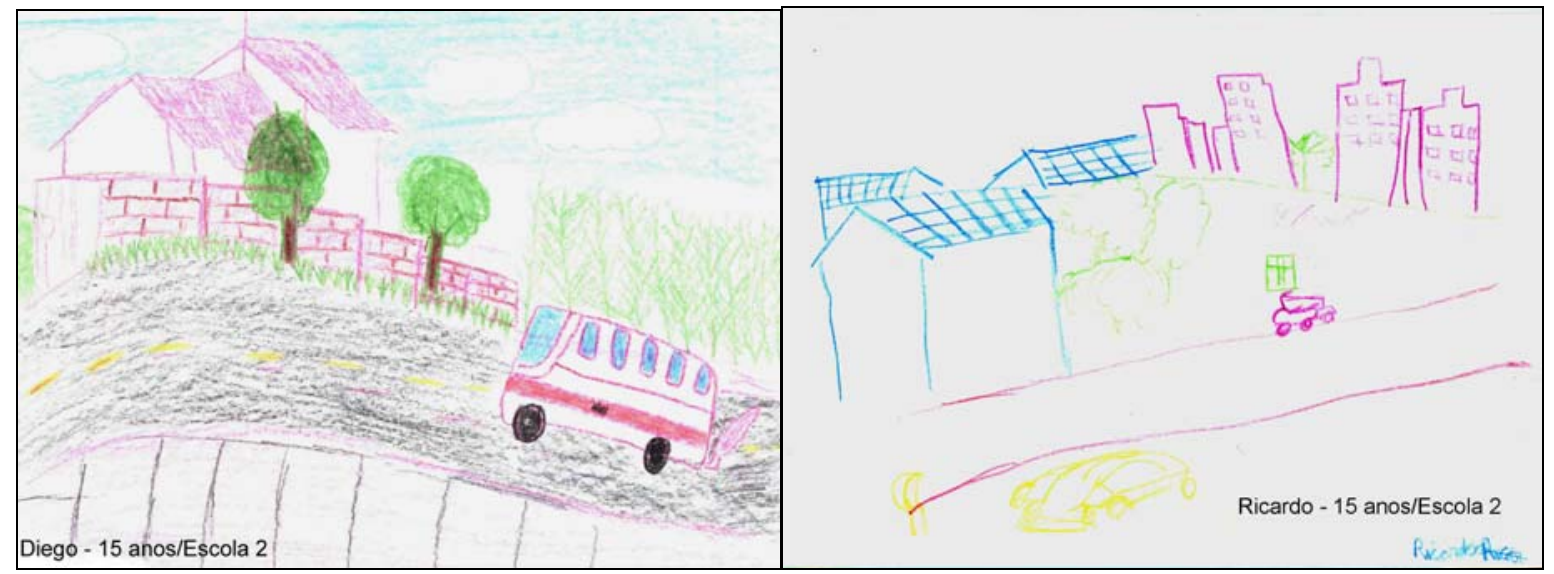

Figura 25 - Desenho de Diego da Escola 2

Figura 26 - Desenho de Ricardo da Escola 2

Os dois trabalhos acima demonstram com clareza como o brilho do preenchimento do desenho com as cores, na figura 25 , em contraste com o desenho em linhas da figura 26, ganha em vigor e vivacidade. Os dois trabalhos são de alunos da mesma escola, realizados no mesmo dia e a partir da observação da mesma paisagem, tanto que a distribuição dos elementos é basicamente a mesma com uma diferença no enquadramento à direita.

E o segundo aspecto é que o giz de cera combinado com o papel sulfite preenche o requisito básico de acessibilidade do preço. É um material barato, facilmente encontrado, o que possibilitou o fornecimento do material aos alunos em todas as escolas, padronizando o experimento.

Utilizar giz de cera e papel sulfite foi uma maneira de manter uma homogeneidade mínima na aplicação da atividade nas várias escolas a fim que os resultados pudessem ser comparados. Em todas as escolas visitadas, na primeira etapa dos trabalhos de campo, o material foi fornecido aos alunos como forma de eliminar imprevistos com grupos que não tivessem ou não pudessem providenciá-lo. 
$\mathrm{Na}$ atividade Paisagem e uso do solo: leitura gráfica (Quadro 1), foi utilizado papel vegetal na construção do overlay. Nesse caso, o papel vegetal foi introduzido por oferecer a transparência mínima necessária à leitura e visibilidade das figuras representadas. O giz de cera foi mantido nessa atividade por proporcionar uma cobertura de cores razoavelmente homogênea e com maior velocidade de aplicação.

\subsubsection{O Roteiro Final de Atividades}

Como já foi observado anteriormente, foram elaboradas três versões sucessivas do roteiro de atividades durante a primeira etapa dos experimentos, sendo que a terceira versão é a que foi apresentada aos professores participantes da Oficina e cujo desenvolvimento teve acompanhamento somente à distância.

Uma descrição detalhada desse roteiro final permite compreender as mudanças e adaptações adotadas no decorrer dos experimentos nas escolas 1, 2 e 3. O roteiro final está dividido em 9 atividades denominadas por letras de $A$ a $l$.

\section{Atividade A - Desenhando e pintando a vista da janela}

$\mathrm{Na}$ atividade $A$, Desenhando e pintando a vista da janela, os alunos foram convidados a realizar o desenho e pintura da vista da janela, supondo-se que a vista da janela permita uma visão mínima da rua e arredores, o que na prática não aconteceu em nenhuma das escolas 1,2 ou 3, obrigando a realização dessa atividade na rua, como descrito na atividade $H$.

Nessa atividade e na seguinte, a palavra paisagem não foi mencionada propositalmente, pois um dos objetivos foi avaliar se os alunos identificavam a vista 
da janela como uma paisagem e utilizar essa avaliação como introdução à discussão na seqüência de atividades.

Essa atividade, Desenhando e pintando a vista da janela, não sofreu nenhuma modificação ao longo da elaboração e desenvolvimento do roteiro e tem como objetivos: proporcionar ao aluno oportunidade de se expressar através das linhas, formas e cores, induzi-lo à observação da paisagem e utilizar o desenho como objeto de avaliação do estágio de percepção e representação da paisagem do entorno da escola. Nenhuma orientação sobre a diferença entre desenho e pintura foi realizada durante essa atividade. Os alunos ficaram livres para realizar o desenho pintado-o ou não.

A atividade $A$ permite ao aluno que ele conheça um pouco mais da paisagem do entorno, à medida que a observação e a busca em traduzi-la em desenho obriga-o a um enquadramento, a uma seleção dos elementos observados, a um olhar que revela e instiga-o a criar. Ou seja, a traduzir o observado, de imagem mental para imagem visual, em linhas, em formas e cores. É um trabalho de percepção e de identificação da parcela de realidade física e da parcela de subjetividade representada num quadro (SAUTTER, 1980, p. 107). A partir dessa identificação iniciamos a construção da noção de paisagem geográfica.

\footnotetext{
O olhar a paisagem sempre foi e será um olhar, ao mesmo tempo redutor, pois não consegue captar com ele toda a diversidade e complexidade do real, o que cobra uma seleção dos elementos observados conforme as necessidades, interesses, experiência e prazeres pessoais, tanto do pintor ou interessado pela pintura. Mas, também, esse é um olhar criador, pois supre essa deficiência dos limites do olhar com o uso da imaginação e da habilidade técnica, recriando determinados aspectos do real que se almeja representar, desde cores, tons, objetos, até humores, riquezas e misérias. (FERRAZ, 2001, p.154)
}

A atividade contém, em parte, uma proposta de treinamento do olhar sobre a paisagem e que é uma etapa importante da construção do conceito tanto em geografia quanto em artes. 
O tempo dedicado à observação e à realização do desenho foi previsto como o mínimo suficiente para que os alunos realizassem a atividade com bastante objetividade sem tempo para desviar a atenção e para que não se cansassem, ou seja, em torno de 20 a 30 minutos. Também foi planejado para que ainda na mesma aula fosse aplicada a atividade $B$, respondendo as questões do exercício escrito.

Para realizar o desenho e pintura, os alunos foram orientados a se utilizarem somente do giz de cera, sem uso de lápis e borracha para fazer rascunho, pois não haveria tempo. Não foi dada nenhuma orientação sobre técnica de desenho, somente a recomendação de que procurassem desenhar e pintar cores e formas em definitivo, pois não haveria tempo posterior para passar os desenhos a limpo.

\section{Atividade B - Diagnóstico de paisagem e seus elementos}

A atividade $B$, Diagnóstico de paisagem e seus elementos, também não sofreu modificações ao longo dos experimentos. Trata-se do exercício escrito $n^{\circ} 1$ que foi respondido individualmente para avaliação diagnóstica e verificação do conceito de paisagem trazido pelos alunos, a realização de um inventário dos elementos da paisagem observada, qual a percepção da paisagem do entorno da escola e o quanto a dificuldade ou não de desenhar e pintar limitou a expressão e a representação desses alunos, segundo eles próprios.

O exercício escrito $n^{\circ} 1$ consta das seguintes questões: 1) Você acha que o que você viu e pintou é uma paisagem? Por que?; 2) O que é uma paisagem para você?; 3) Descreva o que você viu pela janela, fazendo uma lista com tudo que se lembrar; 4) Que tipo de sentimento ou sensação você tem em relação ao que se vê da janela?; 5) Você acha que aquilo que você viu e pintou tem alguma coisa a ver com você? Por que?; 6) Se você fosse um grande desenhista e pintor o que você faria de diferente no seu desenho? 
A pergunta 1 foi realizada com o intuito de avaliar se os alunos entendem que a vista da janela da escola e o desenho realizado por eles é uma paisagem e o que os faz pensar assim, já orientando-os para a resposta da questão 2, que também é uma forma de avaliação. A descrição dos elementos da paisagem na questão 3 objetivou subsidiar a etapa seguinte das atividades, quando os alunos deveriam refletir sobre as funções das paisagens a partir de seus componentes.

A quarta questão buscou mapear sentimentos relativos à paisagem da janela para avaliar posteriormente, em comparação com o exercício final, se é possível modificálos a partir do trabalho realizado em sala de aula e também tinha o intuito de investigar, ainda que superficialmente, aspectos relacionados à topofilia - "elo afetivo entre a pessoa e o lugar ou ambiente físico" (TUAN, 1974, p 5)

\footnotetext{
As imagens da topofilia são derivadas da realidade circundante. As pessoas atentam para aqueles aspectos do meio ambiente que lhes inspiram respeito ou thes prometem sustento e satisfação no contexto das finalidades de suas vidas. As imagens mudam à medida que as pessoas adquirem novos interesses e poder, mas continuam a surgir do meio ambiente: as facetas do meio ambiente, previamente negligenciadas são vistas agora com toda claridade. (TUAN, 1974, p. 137)
}

Apesar de Tuan estar se referindo ao conceito de meio ambiente e não de paisagem, o que queremos destacar é a mudança na percepção conforme as mudanças nos valores. Esse processo que interfere nos valores, nas atitudes, nos sentimentos em relação ao meio ambiente também pode ser transferido para a paisagem e é parte do que se buscou atingir com o conjunto de atividades propostas, por isso foi feita uma avaliação inicial e a questão foi repetida no final dos trabalhos.

A questão 5 foi dirigida com o mesmo objetivo anterior, a fim de compreender se havia um sentimento de pertencimento entre os alunos e a paisagem e qual o entendimento que eles têm de que são agentes e não só observadores dessa paisagem. 
A última questão pretendeu avaliar como os alunos entendiam a expressão através do desenho e da pintura. Se havia a preocupação com a realização de um desenho que fosse cópia do real e o quanto esse desejo e a visão idealizada do desenho e da pintura perfeitos interferiu na expressão desses jovens. Pretendeu avaliar também quanto a dificuldade ou o não domínio de técnicas de desenho limitou a expressão dos alunos segundo a avaliação dos mesmos.

Foi previsto um máximo de quinze minutos para a realização das respostas, sendo que dos 8 grupos avaliados somente 3 necessitaram de uns minutos a mais. As perguntas dessa atividade e também todas as atividades envolvendo questões escritas foram entregues aos alunos em folhas com as questões já preparadas para o aluno somente escrever suas respostas.

\section{Atividade $\mathrm{C}-\mathrm{O}$ que é paisagem?}

Os resultados do exercício escrito número 1 , atividade $B$, orientaram a atividade $C, O$ que é paisagem?, que objetivou a desconstrução e a construção do conceito de paisagem dos alunos. Já era previsto, pela experiência acumulada em sala de aula e pela pesquisa em bibliografia consultada ${ }^{13}$, que possivelmente uma parcela dos alunos viesse com o conceito equivocado de que paisagem tem que ter elementos naturais ou "que tenha natureza ao redor"14 (Karina, 25 anos, 6a A da escola 1) e "para formar uma paisagem tem que ter muitas coisas bonitas" (Jhonatan, 12 anos, $6^{a}$ série da escola 3 ).

Na atividade $C$, o intuito foi introduzir os dois quadros de paisagem da cidade de São Paulo, Aspectos de São Paulo e Teatro Municipal e a discussão orientou-se para a comparação entre os elementos enumerados pelos alunos na questão 3 do exercício 1, relativos à vista desenhada (e que vários alunos não entendiam como uma

\footnotetext{
${ }_{13}^{13}$ Principalmente CARDOSO, 1999 e CAVALCANTI, 1996.

14 Todas as frases de alunos e professores citadas nessa dissertação foram transcritas como estão nos documentos originais, preservando-se as construções e pontuações dos autores.
} 
paisagem) e os quadros observados que, no caso das escolas 1, 2 e 3, todos os alunos concordaram ser paisagens.

Essa atividade $C$, no roteiro final, teve ainda a inclusão do quadro Paisagem com Animais (figura 8 - identificado pelo $\mathrm{n}^{\circ} 3$ nos exercícios). A introdução desse quadro objetivou identificar as paisagens rurais em suas formas, estruturas e funções em comparação com as paisagens das áreas urbanas, dos quadros 1 (figura 6) e 2 (figura 7).

O quadro Teatro Municipal (figura 7), quando observado pelos alunos na escola 1, não deixou dúvidas sobre ser uma paisagem urbana, uma vez que a representação traduz exatamente a imagem contemporânea do urbano, é a cidade com altos edifícios construídos muito próximos uns dos outros, extensas e largas vias de circulação com muitos veículos passando e um céu sempre tomado por uma faixa escura de fumaça. Todavia, o quadro Aspectos de São Paulo (figura 6) suscitou dúvidas devido à presença de animais de carga, riacho com pessoas utilizando-se da água e sugerindo ausência de poluição, presença de vegetação e árvores espalhadas, dentre as construções somente casas e sobrados baixos sem edifícios altos.

Na prática, a dinâmica da atividade aconteceu a partir da enumeração dos elementos das paisagens pintadas comparados com os elementos elencados na questão 3 do exercício 1, quando foi possível mostrar aos alunos que a vista da janela também é paisagem, mesmo não sendo bonita ou tendo pouca natureza. Ou seja, os alunos perceberam que seus desenhos, os quadros e a vista da janela contém, basicamente, os mesmos elementos. Porém, na comparação entre o urbano e o rural projetou-se a questão sobre a função desses elementos, o funcionamento e a relação entre eles que foi respondida na análise do uso do solo nas atividades $D$ e $E$ do roteiro final. 
Essa atividade $C$ foi de extrema importância para introduzir a noção polissêmica do conceito de paisagem, diferenciar paisagem na arte e paisagem geográfica a partir dos quadros e dos desenhos dos alunos, além de propor a questão sobre as funções das paisagens, distinguindo rural e urbano.

\section{Atividade D - Paisagem e uso do solo: leitura gráfica}

A atividade $D$, chamada Paisagem e uso do solo: leitura gráfica, foi inserida no roteiro a partir dos experimentos realizados na escola 2, com base nos resultados das atividades da escola 1. Na escola 1, a dúvida e a insegurança dos alunos relativas às paisagens rural e urbana, demonstrou a necessidade de aprofundar a análise das diferenças entre ambas. A fim de identificar essa diferença a partir do uso do solo, os alunos trabalharam em grupos na construção de overlays com papel vegetal sobre a reprodução dos quadros Teatro Municipal (figura 7) e Paisagem com Animais (figura 8).

Utilizando papel vegetal e giz de cera os alunos construíram um overlay para cada um desses dois quadros. Foi sugerida aos alunos uma legenda com as seguintes cores: laranja para áreas de edificações (casas, edifícios comerciais e residenciais), verde para áreas verdes (parques, plantações, árvores isoladas, jardins, pastos, etc), marrom para as vias de circulação (ruas, avenidas, pontes, caminhos, etc), azul escuro para as águas (lagos, rios e mar) embora nenhum dos quadros apresentasse representação de água e azul claro para a área do céu (somente no intuito de preencher todo o overlay com cores) .

\section{Atividade E - Paisagem e uso do solo: urbano e rural}

A atividade seguinte, Paisagem e uso do solo: urbano e rural, também foi incluída a partir dos trabalhos realizados na escola 2 e nela professor e alunos discutiram sobre 
os resultados das porcentagens das áreas coloridas no overlay, estabeleceram as relações entre as atividades primárias, secundárias e terciárias e uso do solo nas paisagens urbanas e rurais e também a relação campo-cidade. Foram feitas reflexões sobre porque a paisagem muda e quem a constrói, preparando os alunos para o exercício escrito número 2 a seguir, em que eles fizeram comparações entre as paisagens do quadro Aspectos de São Paulo e Teatro Municipal do ponto de vista das mudanças na paisagem geográfica.

\section{Atividade F - Por que a paisagem muda?}

O objetivo da atividade $F$, Por que a paisagem muda?, é levar o aluno a atentar para o arranjo da paisagem da cidade de São Paulo, sua elaboração, observar o funcionamento dessa paisagem como resultado da ação dos interesses dos grupos humanos e dos indivíduos.

A atividade $F$ pretende estabelecer uma conexão com o aprendizado e a experiência anterior do aluno em geografia através de exercícios que solicitam reflexões sobre aspectos gerais do que Claval chama de espaço humanizado.

\footnotetext{
Os grupos humanos transformam os meios naturais onde se instalam. As florestas e as planícies selvagens cedem lugar ao xadrez dos campos; as casas são agrupadas em vilas, as construções urbanas alastram-se como mancha de óleo e projetam seus tentáculos sobre os campos circundantes; os caminhos, as estradas, as vias férreas, as linhas de força elétricas encerram todo o espaço numa malha de meios de comunicação sem a qual não haveria vida social possível. A paisagem humanizada toma formas variadas que refletem as escolhas e os meios de diferentes culturas. (CLAVAL, 1995, p. 287)
}

O objetivo desse exercício está voltado para aspectos conceituais relacionando-o à percepção sobre a paisagem e suas representações. Fazendo a revisão de alguns conteúdos em geografia, o exercício pretende contribuir para a construção da noção de paisagem geográfica a partir das representações dos quadros. 
[...] a paisagem representada numa pintura expressa as formas de se olhar o mundo a partir das condições históricas, culturais, políticas, éticas, estéticas, técnicas e tecnológicas que o pintor e o público estavam inseridos. Tal fato, portanto, permite-nos colher noções que, mesmo que a pintura não expresse a realidade em sua inteireza, auxilia a uma melhor compreensão da visão que os indivíduos e a sociedade possuíam de sua espacialidade em determinada época e lugar. (FERRAZ, 2001, p. 154)

Os alunos trabalharam em grupos para resolver o exercício escrito 2 que é um pequeno roteiro de observação das reproduções dos quadros Aspectos de São Paulo (figura 6) e Teatro Municipal (figura 7). O exercício solicitou aos alunos que apontassem as principais mudanças ocorridas na cidade de São Paulo entre 1942 e 1985 (são as datas dos dois quadros, respectivamente) que podem ser verificadas através dos quadros: a) nos meios de transporte; b) população; c) habitação; d) influência sobre a fauna (animais); e) influência sobre a flora (áreas verdes); f) rios; g) cultura (religião, teatro, cinema, festas de rua, pessoas de outras nacionalidades, etc); h) atividades econômicas (agricultura, pecuária, extrativismo, comércio, indústria, etc); i) Por que a paisagem muda?; j) Quem constrói a paisagem?

Nem tudo o que foi solicitado aos alunos está explícito nas imagens, porém com a orientação dos professores pôde ser resolvido e discutido nos grupos. Da letra a) à letra h), as questões são pontuais e mais factuais. Porém, as questões i)Por que muda a paisagem? e j)Quem constrói a paisagem? têm o objetivo de induzir os alunos a identificarem o homem como indivíduo social, agente da paisagem, que contribui para modelar permanentemente a mesma.

Os alunos foram solicitados a procurar nas imagens representadas o que está implícito e não necessariamente o que está aparente. A resposta sobre o que mudou na cidade de São Paulo em 40 anos, não está somente na aparência das figuras desenhadas, mas no que essas figuras representam em cada um dos quadros: o que tem por trás dos edifícios pintados ao lado do Teatro Municipal, são pessoas morando ou trabalhando? Trabalhando em quê? O papel do professor nessa atividade foi o de auxiliar os alunos a fazerem as perguntas adequadas a si mesmos, 
para que obtivessem as melhores respostas sobre padrões e processos na paisagem geográfica.

\section{Atividade G - Novo olhar sobre o desenho e a pintura}

A atividade $G$, Novo olhar sobre o desenho e a pintura, objetivou instrumentalizar o aluno para que ele melhorasse seu desempenho na retomada do desenho de paisagem. Essa etapa se constituiu de orientações sobre o uso de cores, e ferramentas para representar a profundidade e como fazer um desenho de paisagem.

Ao realizar seus estudos sobre a representação do espaço na criança, Piaget referese à representação espacial como uma ação interiorizada, ou seja, é mais do que a evocação de objetos reais, mas sim uma forma de ordená-los internamente, operando com objetos simbolizados. Seguindo esse princípio, a atividade $G$, pretendeu contribuir na melhora da capacidade dos alunos de expressar essa ação interior sobre a paisagem.

Ao refletir sobre a perspectiva como técnica para o desenho, o aluno estará também refletindo sobre a escala da paisagem observada, os planos e os elementos correspondentes a cada plano da paisagem e o ponto de vista a partir do qual ele observa a paisagem.

Essa atividade também esteve dirigida para aspectos da arte e da estética e nesse sentido, as discussões foram dirigidas para as curiosidades sobre os pintores, estilos, gêneros e materiais. A partir das escolas 2 e 3, essa atividade incorporou uma seleção de 6 quadros (figuras 19 a 24) de gêneros variados e uma discussão sobre o significado das informações relativas à obra de arte: nome do pintor, título, material, tamanho da pintura e acervo. 
$\mathrm{Na}$ escola 1, esses 6 quadros não foram utilizados e a discussão sobre as informações das obras foi realizada durante a atividade Lendo e Apreciando Quadros que foi suprimida a partir dos experimentos nas escolas 2 e 3 e incluída como atividade complementar 1 , no roteiro final. Sendo assim, a atividade $G$ ficou um pouco mais longa, tendo como tempo previsto de 15 a 20 minutos.

\section{Atividade $\mathrm{H}$ - Novo olhar sobre a paisagem}

A atividade $H$, Novo olhar sobre a paisagem, é outro desenho de paisagem. Nela os alunos retornaram ao mesmo lugar em que estiveram na primeira etapa (a sugestão é a janela) e redesenharam a paisagem. Para que o aluno se sentisse familiarizado com aquela paisagem e aproveitasse melhor a nova oportunidade, considerou-se importante retornar exatamente ao mesmo ponto inicial. Os materiais e as condições foram as mesmas, com exceção da solicitação explícita para que os alunos desenhassem e pintassem a paisagem.

No caso das três escolas em que as atividades foram aplicadas, na primeira etapa de experimentos, as janelas nas salas de aula não possuíam vistas para a rua. $\mathrm{Na}$ escola 1, com autorização da direção, os alunos foram levados à passarela que cruza a Rodovia que fica a $200 \mathrm{~m}$ da escola. Na escola 2 , os alunos foram à rua, na frente da escola e na escola 3 , todas as atividades foram desenvolvidas numa área externa da escola, cercada e coberta, semelhante a um terraço, que ficava no alto do prédio em relação à rua, com visão de $180^{\circ}$ dos arredores.

A ausência de janelas com vistas para a rua nas três escolas, trouxe reflexões e representou vantagens e desvantagens, discutidas no capítulo 6. Na primeira escola foi previsto que ao final das atividades os alunos fariam novamente o mesmo desenho e pintura, só que nesse momento receberiam orientação e levariam consigo o reflexo das discussões realizadas ao longo de 4 ou 5 encontros. 
No dia da realização dessa atividade na escola 1, choveu, e foi necessário adiar a saída para desenhar e pintar na passarela, demandando novo acordo com professor e direção da escola para que mais um dia, pelo menos, fosse destinado à realização do roteiro completo. Embora nem o professor de geografia nem a direção da escola tenham demonstrado desagrado ou rejeição pela prorrogação dos trabalhos, os alunos ficaram ansiosos e isso trouxe a insegurança de que o imprevisto da chuva pudesse vir a se repetir para aquela escola e para as outras também.

Essa insegurança resultou na supressão do desenho final do roteiro aplicado nas escolas 2 e 3. Porém, realizada a avaliação dos resultados nas três escolas, concluiu-se sobre a importância da retomada dessa expressão através do desenho no final das atividades, por isso o roteiro básico final incluiu novamente a realização dessa atividade em que alunos, apoiados na orientação sobre técnicas de desenho e profundidade, nas reflexões sobre paisagem em arte e geografia e após a experiência e o contato com obras de arte, voltam ao mesmo local da Atividade $A$ com outro estímulo. Através dessa atividade é possível avaliar se os alunos modificam o enquadramento ou se há mudança na maturidade e na categoria de representação, se mais esquemático, enumerativo ou orgânico dentre alguns tipos citados por Read (1958, p. 171).

Outro aspecto importante que relaciona o desenho com a apreensão da paisagem em geografia é apontado por Gonthier-Cohen, que destaca a importância do desenho para o geógrafo na elaboração de análises, deduções, confrontações de hipóteses e pontos de vista, traduzindo graficamente estudos científicos.

\footnotetext{
L'absence de formation plastique entrave la compréhension à deux niveaux. En premier lieu, elle génère des problèmes de lecture d'images, qu'il s'agisse des documents liés à la parole de l'enseignant et se voulant son soutien illustratif. D'autre part, elle entrave la progression de l'étudiant en le plaçant dans une situation d'incapacité, de soumission, de subjugation ou de rejet vis-à-vis des arts plastiques. Donc en le privant de savoirs opératoires
} 
lui permettant d'accéder à des approches réellement scientifiques. (GONTHIER-COHEN, 1987, p. 52) ${ }^{15}$

A importância dessa atividade também está na oportunidade do aluno em expressarse, como explica Read (1958, p. 199), quanto mais o indivíduo acumula percepções, maior a necessidade de expressão, uma vez que a comunicação é uma atividade social e o homem é um ser social. Há várias formas do indivíduo expressar-se e o desenho e a pintura é uma delas.

\section{Atividade I - Avaliação Final}

Na última atividade, Avaliação final, os alunos fazem uma avaliação das impressões que tiveram durante todas as atividades e algumas questões sobre o conceito e a percepção sobre a paisagem são retomadas, agora com a palavra paisagem aparecendo em lugar da palavra vista utilizada no exercício escrito 1.

Essa avaliação final contém as seguintes questões: 1) O que você achou mais cansativo durante essas atividades?; 2) O que você achou mais interessante durante essas atividades?; 3) O que é paisagem pra você?; 4) O que você acha da paisagem que se vê da janela?; 5) O que você aprendeu com essas atividades?

Iniciar a avaliação pelos aspectos negativos e positivos foi uma tentativa de captar as impressões mais imediatas dos alunos a respeito do que eles entenderam do conjunto de atividades, se foi como um evento comum, diferente, bom ou ruim. $O$ intuito de perguntar novamente o que é paisagem foi verificar se as atividades influenciaram de alguma forma a expressão escrita e a compreensão da noção do conceito.

\footnotetext{
15 "A ausência de formação plástica dificulta a compreensão em dois níveis. Em primeiro lugar, ela gera problemas de leitura de imagens, que dinamizam documentos ligados à fala do professor e que são sustentações ilustrativas. De outra lado, ela dificulta a progressão do estudante colocando-o numa situação de incapacidade, de submissão, sujeição ou de rejeição frente às artes plásticas. Portanto, privando-o dos saberes operatórios que o permitiriam acessar às aproximações realmente científicas." (tradução nossa)
} 
A quarta questão foi uma retomada da topofilia. Essa questão comparada com a realizada no exercício 1 da atividade $B$, verificou se alguma mudança ocorreu, mesmo num curto intervalo de tempo e reduzida vivência. $E$ a pergunta final, número 5 , foi acrescida a partir dos trabalhos de campo nas escolas 2 e 3 , a fim de identificar como os alunos apreenderam os objetivos do conjunto de atividades.

As atividades $A$ a / formam o roteiro básico, e os exercícios realizados na escola 1 que foram suprimidos pela escassez de tempo ou necessidade de melhor planejamento ou envolvimento de outros professores - como por exemplo o professor de português no acompanhamento e leitura dos textos -, permaneceram como sugestões de atividades complementares.

\section{Atividade Complementar 1}

A atividade Lendo e apreciando quadros foi suprimida nas escolas 2 e 3 em razão da necessidade de dedicar mais tempo à sua execução. A maior parte dos alunos da escola 1 demonstrou pouca intimidade com a linguagem dos quadros o que obrigou a uma dedicação maior à atividade. Como o objetivo geral da pesquisa sempre esteve mais voltado à noção de paisagem geográfica e secundariamente ao estudo das representações paisagísticas em arte, a escassez de tempo resultou na supressão da atividade.

Algumas questões e reflexões propostas na atividade Lendo e apreciando quadros foram realocadas para outras atividades e desenvolvidas nas escolas 2 e 3 , sendo que o esquema geral da atividade foi transformado na atividade complementar 1 , cujo procedimento consiste em realizar a análise e comparação dos quadros 1 e 2 em termos de forma e conteúdo: desde o nome do quadro, nome do pintor, dimensões da obra, material utilizado, até aspectos de profundidade, estilo, cores, predominância de linhas e ritmo do quadro. (Apêndice $B$ ) 
O objetivo da atividade complementar 1 é aproximar o aluno da linguagem plástica e contribuir na desaceleração do olhar para a pintura, uma vez que o espectador contemporâneo tem seu olhar treinado pela mídia que utiliza e descarta imagens numa velocidade muito rápida, comparada aos padrões necessários à apreciação em artes plásticas.

\section{Atividade Complementar 2}

A atividade complementar 2, A paisagem geográfica na paisagem pintada, que foi desenvolvida durante o roteiro aplicado na escola 1, constitui-se de dois textos, a letra da canção "São Paulo São Paulo"16, um extrato do capítulo "São Paulo tem má reputação"17 (Anexo A) do livro Um Olhar Francês sobre São Paulo e dez quadros de paisagens (figuras 9 a 18). No caso dos textos, são olhares diferentes sobre a paisagem paulistana e que evidenciam percepções distintas, do bem humorado e cínico ao realista e poético.

A inclusão dos dois textos objetiva aproximar os alunos das paisagens de São Paulo rompendo com a visão de que paisagem é algo bonito, perfeito e repleto de elementos da natureza. Os dois textos são uma oportunidade dos alunos se defrontarem com percepções e representações diferenciadas da cidade, que destacam os problemas, a poesia, a ironia e aspectos da cultura urbana de São Paulo.

A dinâmica proposta para essa atividade é que cada grupo de alunos fique responsável por um quadro e procure identificar nos textos, frases que correspondam às imagens representadas nos quadros.

\footnotetext{
${ }^{16}$ Letra de canção de Osvaldo, Biafra, Claus, Marcelo e Vandy, interpretada pelo grupo Premeditando o Breque. É uma paródia da canção "New York New York".

${ }_{17}$ Fragmento de capítulo de mesmo nome do livro Um Olhar Francês sobre São Paulo, de Claude Olievenstein e François Laplantine, Editora Brasiliense, São Paulo, 1993.
} 
Os grupos recebem um guia de observação dos quadros (Apêndice C) e apontam nos textos quantas frases entenderem que identificam as imagens dos quadros $\mathrm{e}$ depois devem justificar suas escolhas por escrito. Cada grupo deve expor os resultados aos demais colegas da sala. É importante dedicar tempo à leitura dos textos e apreciação da canção antes de realizar a apresentação final da atividade, como foi feita com os alunos da escola 1.

O objetivo desse exercício é o treino da reversibilidade das linguagens na percepção e leitura de paisagem e a reflexão sobre a distinção entre objetividade e subjetividade na representação da paisagem.

Durante o desenvolvimento dessa atividade na escola 1, os alunos escutaram a música acompanhando a leitura da letra e demonstraram simpatia para com a canção, porém, durante a leitura do texto seguinte, durante toda a atividade de busca de comparações entre o texto e as reproduções dos quadros e também durante a apresentação das justificativas das escolhas das frases dos textos, foi enorme a demonstração de desinteresse, desconcentração e incapacidade dos grupos para a leitura e para utilizar a linguagem escrita para expor as opiniões e idéias.

A exclusão da atividade $A$ paisagem geográfica na paisagem pintada do roteiro final, deu-se pela característica descritiva dos dois textos, pontuados por muitas metáforas e considerados pelo professor da escola 1 como "muito densos" para o nível daqueles alunos ( $6^{\mathrm{a}}$ série-suplência). Logo nos primeiros momentos, verificou-se que alguns alunos possuíam leitura silábica, com dificuldades em articular uma frase completa na leitura e na escrita. A dificuldade em compreender os textos resultou num dos momentos, dentre todas as atividades do roteiro, como de maior dispersão e falta de interesse dos alunos. 
Concluiu-se que seria necessário dedicar muito mais tempo aos textos para que o aproveitamento fosse próximo do ideal. Diante da dificuldade em ampliar o tempo do experimento nas outras escolas e também por acreditar que a substituição dos textos por outros mais simples não amenizaria a dificuldade de leitura dos alunos e mesmo sabendo que os alunos teriam perfis diferentes nas escolas seguintes, a atividade foi suprimida do roteiro de atividades aplicado nas escolas 2 e 3 e do roteiro final e incluída como sugestão de atividade complementar 2, considerando-se que seria mais produtivo testar outro conjunto de atividades mais de acordo com a proposta de construção do conhecimento a partir de imagens e da arte.

Entretanto, nenhum dos professores que participaram da Oficina aplicou essa atividade integralmente com seus alunos, ficando assim o experimento restrito à escola 1. Os resultados das atividades revelam que os textos foram utilizados parcialmente em algumas instituições participantes da segunda parte dos experimentos

O quadro 2 apresenta uma síntese das atividades realizadas na primeira fase de experimentos e quais foram incluídas no roteiro final, desenvolvido na segunda fase de experimentos. 


\begin{tabular}{|c|c|c|c|}
\hline Atividades & Escola 1 & Escolas 2 e 3 & Roteiro Final \\
\hline $\begin{array}{c}\text { A - "Desenhando e pintando a vista da } \\
\text { janela" }\end{array}$ & realizada & realizada & incluída \\
\hline $\begin{array}{l}\text { B -"Diagnóstico de paisagem e seus } \\
\text { elementos" (Exercício escrito 1) }\end{array}$ & realizada & realizada & incluída \\
\hline C - "O que é paisagem?" (discussão oral) & realizada & $\begin{array}{c}\text { realizada } \\
\text { (acréscimo do } \\
\text { quadro 3- } \\
\text { paisagem rural) }\end{array}$ & $\begin{array}{l}\text { incluída (acréscimo do } \\
\text { quadro 3-paisagem rural) }\end{array}$ \\
\hline "Lendo e apreciando quadros" & realizada & suprimida & $\begin{array}{l}\text { incluída como atividade } \\
\text { complementar } 1\end{array}$ \\
\hline $\begin{array}{c}\text { "A paisagem geográfica na paisagem } \\
\text { pintada" }\end{array}$ & realizada & suprimida & $\begin{array}{l}\text { incluída como atividade } \\
\text { complementar } 2\end{array}$ \\
\hline $\begin{array}{c}\text { D - "Paisagem e uso do solo: leitura } \\
\text { gráfica" (overlay) }\end{array}$ & não incluída & realizada & incluída \\
\hline $\begin{array}{c}\text { E - "Paisagem e uso do solo: urbano e } \\
\text { rural" (interpretação do overlay) }\end{array}$ & não incluída & realizada & incluída \\
\hline $\begin{array}{c}\text { F - "Por que a paisagem muda?" } \\
\text { (Exercício escrito 2) }\end{array}$ & não incluída & realizada & incluída \\
\hline $\begin{array}{c}\text { G - "Novo olhar sobre o desenho e a } \\
\text { pintura" }\end{array}$ & realizada & $\begin{array}{c}\text { realizada } \\
\text { parcialmente }\end{array}$ & incluída \\
\hline H - "Novo olhar sobre a paisagem" & realizada & suprimida & incluída \\
\hline I - "Avaliação Final” & realizada & realizada & incluída \\
\hline
\end{tabular}

Quadro 2 - Síntese das Atividades Distribuídas nos Experimentos

O roteiro inclui ainda uma ficha de avaliação para o professor (Apêndice $D$ ), que foi elaborada para ser respondida pelo professor de geografia, embora professores de outras áreas tenham participado dos experimentos. Essa avaliação dos professores juntamente com as observações realizadas permitiram verificar as adaptações necessárias para o roteiro final que foi entregue aos professores da Oficina que participaram da segunda etapa dos experimentos. 
Nessa etapa seguinte, essa ficha de avaliação serviu de identificador da opinião dos professores sobre o conjunto de atividades, o grau de valorização que cada um atribui à multidisciplinaridade e à interdisciplinaridade, as dificuldades e identidades que cada um possui com a linguagem plástica e relativas ao conceito de paisagem.

\subsection{Etapa 1 dos Experimentos: Caracterização das Escolas e Alunos}

Essa primeira etapa dos experimentos foi marcada pela preocupação em evitar que as intervenções fossem um problema para a escola ou um inconveniente para os professores e alunos. A opção em realizar o experimento, prioritariamente, com alunos de $6^{a}$ série e em escolas diferentes, também foi um fator limitante para a realização dos trabalhos no momento do contato e acordo com as escolas.

Após conseguir reunir todas as condições mínimas, conjugando datas que não coincidissem com atividades inadiáveis do calendário escolar, professores e escolas que não se opusessem à intervenção de um professor de fora, foi conseguido o consentimento de duas escolas municipais e uma escola privada para realizar a intervenção. Participaram dessa primeira etapa um total de 62 alunos das três escolas, sendo que nem todos os alunos estiveram presentes em todos as atividades.

As escolas municipais se diferenciaram na escolha das turmas. Na escola 10 trabalho foi realizado com alunos adolescentes e adultos com média de idade de 22 anos e que freqüentam a $6^{\mathrm{a}}$ série do Supletivo ${ }^{18}$ e na escola $3 \mathrm{com}$ alunos da $6^{\mathrm{a}}$ série regular com média de idade de 13 anos.

\footnotetext{
${ }^{18}$ No momento da redação desse texto as turmas de Suplência da Rede Municipal de Ensino de São Paulo passaram a ser denominadas "EJA - Educação de Jovens e Adultos".
} 
Nas duas escolas municipais houve a participação e o acompanhamento do professor de geografia que, no caso, era a mesma pessoa nas duas escolas. $E$ foi justamente o contato e a compreensão do professor que facilitaram as duas intervenções. Na escola privada o trabalho foi realizado com os alunos da $6^{a}$ série regular (média de idade de 13 anos), porém o contato inicial foi através da coordenadora pedagógica que propôs a intervenção nas aulas de geografia e história. No caso dessa escola, o contato inicial com os professores aconteceu no mesmo momento em que as atividades se iniciaram, o que inibiu a participação dos mesmos.

\subsubsection{Escola 1: Supletivo de uma Escola Municipal}

A primeira escola onde o experimento foi realizado localiza-se na zona noroeste do município de São Paulo, num bairro de classe média e classe média alta. Nesse texto está identificada pelo número 1. Trata-se de uma escola municipal de ensino fundamental, fundada em 1969, que mantém 3 períodos de funcionamento. No período da manhã concentram-se as turmas de $5^{\mathrm{a}}$ a $8^{\mathrm{a}}$ séries regulares, no período da tarde as turmas de $1^{\mathrm{a}}$ a $4^{\mathrm{a}}$ séries e no noturno somente turmas de suplência de $5^{\mathrm{a}}$ a $8^{a}$ série, sendo que no semestre em que o experimento foi realizado - 2\%2002 não havia turma de $5^{\mathrm{a}}$ série de suplência formada.

Existe infra-estrutura básica na escola 1, não há problemas com luz, água, saneamento e asfalto. Além disso, a escola é bem servida de linhas de ônibus e há uma estação de trens a $1 \mathrm{Km}$ de distância.

A escola 1 possui 10 salas, sendo que em alguns períodos, como o noturno, há salas ociosas. Nenhuma das salas de aula possui janelas com vista para a rua. A escola possui sala de vídeo equipada, sala de leitura com uma professora designada, sala de informática (no momento do experimento encontrava-se em troca 
de equipamentos) com dois Professores Orientadores de Informática Educativa (POIE) designados, ampla sala de professores, sala de JEI (para uso de professores em Jornada Especial Integral), quadra de esportes, área de convivência externa coberta, cozinha e ainda as salas do diretor, da secretaria e da coordenação.

Quanto ao quadro de funcionários, no momento da pesquisa, encontrava-se completo. A escola contava com professores para todos os períodos, diretor, coordenadora pedagógica, secretária, auxiliar de período, além dos funcionários do quadro de apoio em número aparentemente suficiente.

Os alunos da escola 1, em sua maioria, não são moradores das imediações. A escola caracteriza-se por ser uma "escola de passagem", como a identificam os professores e direção da escola. A maior parte dos alunos vem de Osasco e de localidades ao longo da Via Anhangüera. Os alunos que moram nas imediações, em parte, são moradores de uma favela localizada próxima à escola e representam, no máximo, $15 \%$ do total de alunos (informação obtida com o professor de geografia), o restante vêm de outros bairros distantes.

A escola possui serviço de transporte de alunos em dois períodos. Sendo que antes da implantação do novo serviço de transporte da Prefeitura (a partir da gestão de 2001), a escola já possuía um ônibus próprio para fazer o transporte de alunos de um bairro a outro. Em todos os períodos os alunos recebem alimentação na hora do intervalo.

A comunidade, em geral, participa da vida escolar de duas maneiras: nas reuniões de pais e no Conselho de Escola. Não há outro tipo de atividade ou atuação da comunidade além das citadas e a Associação de Pais e Mestres-APM é pouco atuante. 


\subsubsection{Escola 2: Vma Escola Particular}

O segundo experimento foi realizado numa escola particular da zona sul da cidade de São Paulo, no Brooklin Paulista. Uma escola relativamente pequena, que no momento da pesquisa mantinha só o período da manhã em funcionamento com turmas de Educação Infantil, Ensino Fundamental e Ensino Médio ${ }^{19}$, com um total de, aproximadamente, 120 alunos. A média de alunos por sala de aula é de 10 alunos.

Trata-se de uma escola com 29 anos de idade (no ano de 2002), que possui toda infra-estrutura básica e é bem servida de linhas de ônibus a uma quadra de distância. O quadro de funcionários e professores estava completo no momento do trabalho, contando inclusive com um professor de informática.

O espaço físico da escola 2 é compatível com o número de alunos, possui quadra de esportes, área de convivência externa coberta e sem cobertura, possui sala de informática com 10 computadores, sala ambiente para Artes e uma pequena Biblioteca, que apesar do pequeno acervo, empresta livros para os alunos. A escola possui aparelhos de som e vídeo apesar de não ter uma sala especial para esses recursos e nem anfiteatro fechado, somente um pequeno palco na área de convivência externa.

Nenhuma sala de aula possui janela com vista para rua, com exceção de duas salas cujas janelas são bem altas e não permitem ao aluno observar através delas, a menos que seja com ajuda de escadas ou cadeiras. Mesmo assim são salas bem ventiladas e com boa claridade.

\footnotetext{
${ }^{19}$ Educação Infantil compreende as salas com crianças em idade pré-escolar, ou seja do maternal à pré-escola. Ensino Médio corresponde às três séries posteriores à $8^{a}$ série do Ensino Fundamental (conf. nota número 1).
} 
A maior parte dos alunos que freqüentam a escola 2 são moradores das imediações do Brooklin e pertencem à classe média. Em torno de $20 \%$ dos alunos são bolsistas. Quanto à participação de pais, a única forma é através das reuniões bimestrais ou em eventos e festividades, pois a escola não possui um projeto pedagógico que prevê outras formas de participação.

\subsubsection{Escola 3: Vma Turma Regular de Escola Pública}

A terceira escola localiza-se na zona noroeste da cidade de São Paulo, no limite com Pirituba e Osasco. Também é uma escola municipal, com aproximadamente 30 anos e que mantém 3 períodos de funcionamento: das $6 \mathrm{~h} 45$ às $10 \mathrm{~h} 45$, das $11 \mathrm{~h}$ às $15 \mathrm{~h}$ e das $15 \mathrm{~h}$ às $19 \mathrm{~h}$. A escola atende somente alunos de $1^{\mathrm{a}}$ a $8^{\mathrm{a}}$ séries do ensino regular, não há período noturno nem salas para Educação de Jovens e Adultos.

A escola 3 funciona no limite de sua capacidade, com 12 salas de aulas e nenhuma sala ociosa. Possui Laboratório de Informática Educativa e um professor designado para a função de POIE, possui sala de vídeo e sala de leitura embora, no momento dessa pesquisa, não houvesse professor designado para essa última.

O restante do quadro de funcionários estava relativamente completo no momento da pesquisa, há coordenadora pedagógica, diretor e o quadro de apoio estava completo, todavia o professor de geografia, recém chegado à escola, estava com o compromisso de repor todas as aulas de geografia do $1^{\circ}$ semestre em que os alunos não haviam tido professor.

A escola tem, em torno de 1.000 alunos, distribuídos nos três períodos e a maioria, pertencente às classes mais pobres, residentes do bairro e das imediações. Segundo informação do professor de geografia, uma grande parcela dos alunos é 
moradora das várias favelas existentes nas imediações do bairro, que é basicamente residencial.

A escola não tem projetos com participação da comunidade externa e com exceção das reuniões de pais, não há outras formas de participação.

\subsection{Etapa 2 dos Experimentos: Autonomia do Roteiro de Atividades}

A segunda parte dos experimentos foi planejada para ser desenvolvida de forma autônoma e servir de objeto de avaliação sobre a clareza e compreensão da proposta por parte de professores e alunos, a aplicabilidade das atividades e a pertinência das mesmas no processo de formação dos alunos do ensino fundamental.

\subsubsection{Oficina: Paisagem, Arte e Geografia}

Depois de concluída a avaliação dos experimentos realizados nas três escolas, na primeira etapa, o roteiro final contendo o conjunto de nove atividades divididos, de $A$ a $I$, e mais duas atividades complementares, foi delineado e explicado resumidamente num roteiro escrito (Apêndice $A$ ).

O material necessário para o desenvolvimento desse roteiro e mais as atividades complementares foi reunido num kit contendo uma cópia impressa do roteiro escrito, exercícios escritos (número 1, 2, avaliação final, complementar 1 e 2), textos, as três reproduções dos quadros (Aspectos de São Paulo - $\mathrm{n}^{\circ} 1$, Teatro Municipal - $\mathrm{n}^{\circ} 2 \mathrm{e}$ Paisagem com Animais - $\mathrm{n}^{\circ} 3$ ) impressos em cores em papel A4 de $120 \mathrm{~g}$ e um CD contendo uma apresentação multimídia com 93 quadros de paisagens de 11 pintores 
(incluindo quadros do exercício complementar 2), denominado de "Museu Digital" e todos os arquivos dos exercícios em formato *.doc.

Esse kit foi entregue aos professores participantes da Oficina: Paisagem, Arte e Geografia, durante a qual, cada uma das atividades do roteiro, foi minuciosamente apresentada e discutida, juntamente com alguns conceitos de paisagem do ponto de vista da arte e da geografia.

A Oficina teve a participação de um grupo de 38 professores de escolas públicas e ONGs ligadas a projetos sociais e foi promovido e organizado com o auxílio da Academia de Viagens e Turismo $\left(\mathrm{AVT}-\mathrm{Br}^{20}\right)$ que convidou os professores participantes do programa e incluiu a Oficina como parte de seu Ciclo de Oficinas de Estratégias Didáticas Inovadoras.

Participaram da Oficina professores de várias disciplinas além de professores de geografia e artes. O evento durou aproximadamente 3 horas e foi sediado no Departamento de Geografia da Faculdade de Filosofia, Letras e Ciências Humanas da Universidade de São Paulo. Ao final do encontro, os professores que demonstraram interesse em aplicar o roteiro de atividades com seus alunos, receberam o kit com o material completo e firmaram o compromisso de enviar os resultados dos trabalhos juntamente com a avaliação escrita.

Dentre os participantes desse evento, cinco instituições desenvolveram o roteiro de atividades e enviaram o material com os resultados, sendo 3 escolas municipais da cidade de São Vicente/SP, e duas ONGs, de Barueri-SP e Embu das Artes-SP que neste texto serão genericamente identificadas como escolas 4, 5, 6, ONG 1 e 2 respectivamente. Dentre as cinco instituições foram 7 professores envolvidos, sendo

\footnotetext{
${ }^{20}$ A AVT-Br é parte do programa internacional Global Travel and Tourism Partnership-GTTP criado pela American Express Foundation que está em vários países e no Brasil possui mais de 6000 alunos (dados de 2003). Dentre os projetos realizados no Brasil está o Aprendiz de Turismo destinado a jovens do ensino fundamental de escolas públicas.
} 
3 de Geografia, 2 de Artes, 1 de Ciências e uma estudante de Turismo e Hotelaria que atua como professora junto à ONG de Barueri no Projeto Aprendiz de Turismo.

Cada uma dessas cinco instituições desenvolveu as atividades em condições bastante diferenciadas entre si, como pode ser observado no quadro 3.

\begin{tabular}{|c|c|c|c|c|c|c|}
\hline 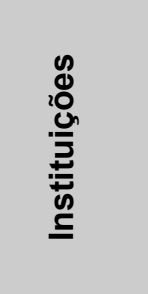 & $\begin{array}{ll}\frac{0}{0} & 0 \\
\frac{\pi}{0} & 0 \\
\frac{0}{0} & \frac{5}{2} \\
\frac{1}{2} & \frac{\pi}{\sigma} \\
\frac{\pi}{2} & 0 \\
0 & 0\end{array}$ & 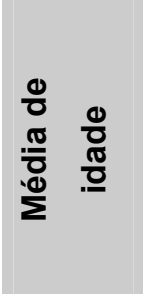 & : & 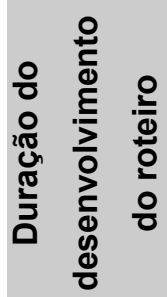 & 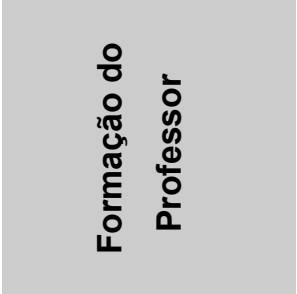 & 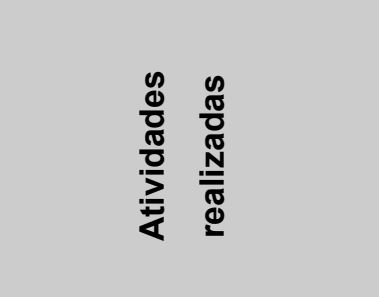 \\
\hline escola 4 & 3 & 11 anos & $\begin{array}{c}\text { alunos de } 5^{\mathrm{a}} \text { e } \\
6^{\mathrm{a}} \text { séries }\end{array}$ & $1 \mathrm{dia}$ & $\begin{array}{l}\text { Profa de }^{\text {de }} \\
\text { Geografia }\end{array}$ & $A, B, C, F, I$ \\
\hline escola 5 & 10 & 13 anos & $\begin{array}{l}\text { alunos de } \\
6^{\mathrm{a}} \text { série }\end{array}$ & 3 dias & $\begin{array}{l}\text { Prof }^{\mathrm{a}} \text { de } \\
\text { Geografia }\end{array}$ & $\begin{array}{c}\text { A, B, C,D, E, F, G, H, I e } \\
\text { complementar } 1\end{array}$ \\
\hline escola 6 & 21 & 12 anos & $\begin{array}{l}\text { alunos de } \\
5^{\mathrm{a}} \text { série }\end{array}$ & 2 dias & $\begin{array}{l}\text { Profa }^{a} \text { de Ciências, } \\
\text { Artes e Geografia }\end{array}$ & $\begin{array}{c}\mathrm{A}, \mathrm{B}, \mathrm{C}, \mathrm{F}, \mathrm{I} \mathrm{e} \\
\text { complementar } 1\end{array}$ \\
\hline ONG 1 & 24 & 16 anos & $\begin{array}{l}\text { jovens de } \\
\text { diversas } \\
\text { escolas e } \\
\text { séries }\end{array}$ & $1 \mathrm{dia}$ & $\begin{array}{c}\text { Estudante de } \\
\text { Turismo }\end{array}$ & $A, B, C, F, I$ \\
\hline ONG 2 & 28 & 18 anos & $\begin{array}{l}\text { jovens de } \\
\text { diversas } \\
\text { escolas e } \\
\text { séries }\end{array}$ & 3 dias & Prof $^{a}$ de Artes & $\begin{array}{c}\mathrm{A}, \mathrm{B}, \mathrm{C}, \mathrm{D}, \mathrm{E}, \mathrm{F}, \mathrm{G}, \mathrm{I} \mathrm{e} \\
\text { complementar } 1\end{array}$ \\
\hline
\end{tabular}

\section{Quadro 3 - Síntese da $2^{\mathrm{a}}$ Etapa dos Experimentos}

Não foi solicitado aos professores que enviassem relatório com a caracterização das instituições e dos indivíduos que participaram das atividades. Porém, é possível realizar uma aproximação, pois as duas ONGs realizam trabalhos voltados para jovens carentes (com idades entre 15 e 20 anos), os mesmos com os quais as atividades foram desenvolvidas. Quantos às escolas 4, 5 e 6, são todas instituições 
públicas de ensino do município de São Vicente, com alunos, em sua maioria, pertencentes às classes média e baixa.

\subsection{A Vtilização de Recursos da Informática no Conjunto do Trabalho}

Durante a pesquisa das reproduções dos quadros utilizados nas atividades foram consultados livros, catálogos de exposições, revistas e principalmente imagens disponíveis na Internet.

Livros de arte e catálogos de exposições foram imprescindíveis, mas por serem materiais caros, raros e cuja reprodução envolve procedimentos complexos, as imagens digitais e as tecnologias da informática foram relevantes na realização da pesquisa, constituindo-se numa alternativa com enorme potencial.

Fazer a seleção das figuras via Internet abriu a possibilidade de imprimir as reproduções no tamanho que fosse conveniente ao trabalho ainda que o resultado dessa impressão não tivesse o mesmo brilho das reproduções dos catálogos ou livros.

Outra vantagem do uso das tecnologias da informática é que todos os desenhos dos alunos participantes da primeira etapa foram digitalizados com o uso de um scanner e organizados numa apresentação multimídia juntamente com as fotografias do registro das atividades e gravada num $C D$. Isso permitiu que os alunos ficassem com um registro do trabalho realizado sem privar o experimento de permanecer com os trabalhos dos mesmos.

O CD com a apresentação multimídia foi elaborado no Illuminatus, versão 4.50, um software autoral que permite a execução do trabalho em outros computadores sem 
necessidade de instalação do programa. Esse software está disponibilizado aos professores e alunos da Rede Estadual de Ensino de São Paulo.

Foram montadas apresentações experimentais com os trabalhos dos alunos das escolas 1 e 2 e essas apresentações estão copiadas no CD anexo a esta dissertação. Foi entregue um CD a cada escola para que os alunos pudessem apreciar seus próprios trabalhos e as fotos realizadas durante o experimento.

A informática foi determinante também na organização e produção do kit que foi entregue aos professores da Oficina. Junto com as reproduções e exercícios impressos, os professores receberam um CD com um arquivo multimídia chamado Museu Digital, também elaborado no software Illuminatus. Essa arquivo continha 93 reproduções digitais de quadros de paisagens de 11 artistas brasileiros, com uma curta biografia de cada pintor. A apresentação é auto-guiada com ícones e setas que professores e alunos podem consultar facilmente.

Paralelamente, o CD do kit entregue aos professores incluía as reproduções de todos os 93 quadros e mais os quadros utilizados nas atividades em formato *.jpg para que os mesmos pudessem ser impressos em caso de interesse dos professores em ampliar o roteiro de atividades, o que facilitou a distribuição do material.

A apresentação experimental, Museu Digital, e as duas montagens realizadas com os desenhos dos alunos das escolas 1 e 2 estão incluídas no CD como um encarte dessa Dissertação. 


\section{Resultados: $\mathcal{A}$ Noção do Conceito de Paisagem a partir dos Experimentos}

"Antes de poder ser um repouso para os sentidos, a paisagem é obra da mente. Compõe-se tanto de camadas de lembranças quanto de estratos de rochas."

Simon Schama

As duas etapas de experimentação tiveram seus resultados avaliados conjuntamente. Esses resultados apresentam-se divididos em três itens nesse capítulo. Um item dos resultados compreende uma avaliação diagnóstica e diz respeito à identificação dos alunos e do conceito de paisagem que os mesmos já tinham, os elementos associados a esse conceito e a capacidade de expressão desses alunos.

O segundo item contempla os resultados atribuídos às atividades propostas no roteiro desenvolvido, relativos ao conceito de paisagem, aos conhecimentos em geografia e em arte, à expressão e entusiasmo dos alunos e às mudanças na percepção. A última parte é o conjunto de avaliações que diz respeito à opinião e à atitude dos professores em relação ao trabalho proposto.

É importante ressaltar que os resultados obtidos na segunda etapa dos experimentos, realizada por sete professores dentre os participantes da Oficina, não se equiparam integralmente com os resultados obtidos na primeira etapa, nas 
escolas 1, 2 e 3. Os professores que participaram da Oficina receberam orientação dos procedimentos mas não, necessariamente, desenvolveram o conjunto de atividades da forma como foi recomendada, o que nos obriga a desagrupar a avaliação de parte dos resultados em alguns momentos, principalmente no que diz respeito à atuação de professores.

Assim, na avaliação diagnóstica e na avaliação geral dos resultados, os trabalhos realizados na escola 4 não foram considerados, uma vez que todas as respostas dos exercícios, individuais e em grupos, foram escritas pela própria professora (ou por uma única pessoa que escreveu também a avaliação do professor) colocando em dúvida a autenticidade da expressão dos alunos. Por se tratar de um grupo de somente três alunos, num universo de 148 indivíduos envolvidos, a exclusão dos trabalhos desses três alunos não interfere significativamente na avaliação geral.

\subsection{Diagnóstico: Desempenho Inicial dos Alunos}

A avaliação do conceito de paisagem que os alunos já tinham antes de iniciar as atividades (Gráfico 1), demonstrou que, no total geral, a maioria, ou seja, $66 \%$ entendiam paisagem como um conceito ligado à arte, à beleza e à natureza. Os conceitos desses alunos estavam ligados à idéia de que paisagem "é um desenho em forma de arte" (William, 13 anos, escola 3), paisagem "é um lugar bonito cheio de arvore muito legal" (Fátima, 16 anos, escola 1) ou ainda a idéia de que paisagem é "tudo que está ligado a natureza" (Wagner, 20 anos, ONG 2) ou "é a natureza" (William Aparecido, 19 anos, ONG 2). 


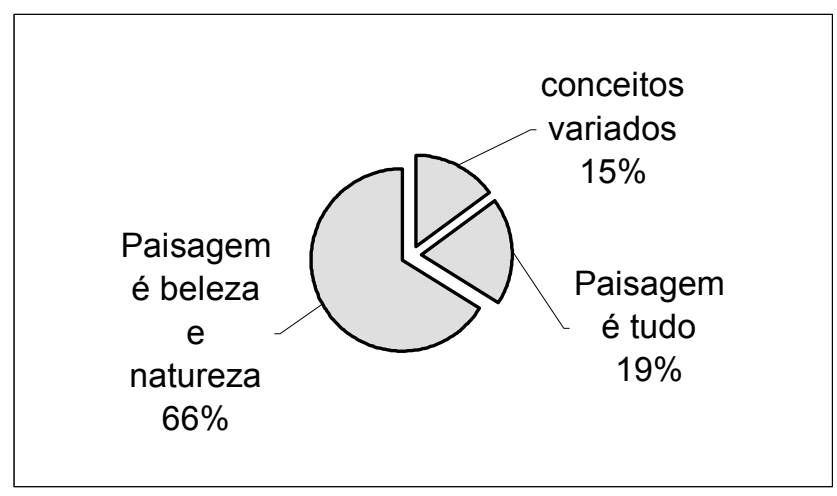

\section{Gráfico 1 - Conceito de Paisagem Anterior às Atividades}

A idéia de paisagem relacionada à natureza ou como sinônimo de natureza é constante e repete-se quando os alunos são questionados sobre a paisagem que observaram e desenharam. Os alunos afirmam terem observado uma paisagem "porque tem árvore" (Angela, 15 anos, escola 3) ou afirmam não terem observado uma paisagem "porque paisagem para mim é a natureza por exemplo, montanhas, lagos e o céu azul e limpo, e aqui a zona urbana é só poluição e casas e edificios então isso para mim não é uma paisagem" (Diego, 15 anos, escola 2).

Outros $19 \%$ dos alunos afirmam que paisagem é "tudo que a gente vê" (Josimar, 14 anos, escola 5). O conceito de paisagem desses alunos aproxima-se bastante da definição presente nos dicionários: "extensão de território que se abrange num lance de vista; panorama, vista." ${ }^{21}$ Alguns acrescentam ao conceito o ponto de vista do qual observam: "Uma paisagem e um lugar muito grande com que eu só possa ver de um lugar alto" (Cléber, 17 anos, escola 1).

Os $15 \%$ restante dos alunos, apresentam conceitos variados relacionados a paisagem como cenário, com relação a movimento, "Paisagem para mim é movimentos, etc..." (Joseane, 16 anos, escola 1), "é algo que nós vemos que não se meche e quando nós queremos vê nós vemos" (Maitê, 11 anos, escola 6) ou então o

${ }^{21}$ Grande Dicionário Larousse Cultural da Língua Portuguesa. São Paulo: Editora Nova Cultural, 1999. 
aluno simplesmente apresentou uma lista de elementos como definição de paisagem: "aonde tem casas, arvore, etc" (Railton, 15 anos, escola 5).

Dentre esses $15 \%$, alguns alunos ainda apresentaram uma tentativa de aproximar o conceito à geografia, inserindo referências ao lugar, ao espaço, à região e à ação do homem: "Conjunto de característica natural artificial que compõe determinado local" (William Araújo, 18 anos, ONG 1), "Para mim uma paisagem é um retrato, uma image que você faz por ver uma região ou um lugar." (Kevin, 12 anos, escola 2).

Esses dados demonstraram que há uma tendência à homogeneidade quanto à concepção de paisagem no grupo pesquisado. Apesar do grupo total de indivíduos ser heterogêneo no que se refere à faixa etária, serem de municípios distintos e origens diversas, não houve diferença significativa de respostas para o conceito de paisagem entre os diferentes grupos, pois o mesmo padrão de respostas foi encontrado nas diversas instituições.

Nota-se que, para esses alunos, paisagem é um conceito com sentido estético, mais relacionado à arte, ao gênero da pintura do que à geografia. É raro identificar alunos se referindo à paisagem geográfica. Como eles não conhecem a distinção polissêmica do termo, o que se verifica é uma associação de paisagem e natureza, que demonstra não só a fragilidade do conceito de paisagem desses alunos, mas também a fragilidade (ou total desconhecimento) do conceito de natureza e da diferença entre esses.

É comum a utilização de termos vagos, como tudo, uma coisa, um lugar, para definir paisagem. É comum também a colocação de conceitos equivocados como "um lugar que o homem não tocou, onde não tem nada feito pelo homem" (Guilherme, 11 anos, escola 6), qualificações sem sentido como "paisagem modificada" ou ainda a visão idealizada de paisagem, "a paisagem pra mim e uma visão de uma floresta, ou o rio no meio dela com uma casa ou sem casa tanto faz" (Reginaldo, 19 anos, ONG 2). 
A partir desse diagnóstico instalou-se um desafio que não pôde ser concluído completamente com o conjunto das atividades desenvolvidas. Diante de um quadro tão sedimentado de conceitos desordenados e equivocados, paralelamente à ação para construção da noção de paisagem geográfica e ampliação da percepção sobre a mesma a partir da arte, ampliou-se a necessidade de desconstruir e organizar idéias pré-concebidas dos alunos que estabelece quais são, a organização e a disposição dos elementos da paisagem.

Os mesmos dados ainda reforçam a idéia de que o conceito de paisagem geográfica não foi trabalhado corretamente com esses alunos ou então sequer foi mencionado anteriormente, uma vez que a maioria dos alunos pertencia à $6^{\mathrm{a}}$ série ou séries mais adiantadas, num momento em que o conceito já deveria ter sido introduzido.

Apesar dos equívocos ou da desorganização nos conceitos de paisagem somente $9 \%$ dos alunos afirmaram não ter observado uma paisagem durante a Atividade $A$. $A$ justificativa dada por esses alunos é quase sempre a de que não viram elementos da natureza e sim poluição e prédios.

A maior incidência dentre esses $9 \%$ concentrou-se nas escolas 1, 2 e 3 da primeira etapa dos experimentos, quando houve uma preocupação em não utilizar a palavra paisagem durante a realização das Atividades $A$ e $B$. É provável que os professores que desenvolveram as atividades nas escolas 4, 5, 6 e ONG 1 e 2 não tenham tido essa preocupação, embora tivessem recebido essa recomendação durante a Oficina.

Foi possível identificar ainda, que na escola 6 , as atividades não foram desenvolvidas na seqüência proposta. A atividade $B$, onde os alunos responderam à pergunta sobre a paisagem observada foi realizada após a apresentação dos quadros de paisagem, como voltaremos a nos referir, o que provavelmente interferiu na avaliação dos alunos sobre a paisagem observada. 
A mesma natureza que esses $9 \%$ não identificaram na paisagem observada serviu para justificar a resposta de uma parcela dos outros $91 \%$ de alunos: é paisagem "por que é uma árvore que é linda" (Fabiana, 12 anos, escola 3), "porque tem muitas árvores" (Camila, 12 anos, escola 6), "sim Tenho a serteza que eu estava desenhando uma Paisagem atras da casa que eu desenhei tinha uma paisagem éra uma mata" (Anderson, 16 anos, ONG 2). Para esses 91\% uma única árvore ou, uma porção de arbustos num plano mais afastado por trás de algumas casas já conferia um caráter de paisagem à vista observada.

A avaliação dos sentimentos e sensações associadas à paisagem observada revelou que em torno de $27 \%$ dos alunos alimenta um sentimento negativo ou indiferença em relação à paisagem observada e praticamente o mesmo índice, $28 \%$, não se identificam com a paisagem observada e pintada. A justificativa freqüente é a de que não gostam da paisagem pois ela está poluída ou há marcas de pobreza. A distribuição desses valores também foi regular entre as diferentes instituições.

Entretanto, a grande maioria dos alunos mantém uma relação de afetividade com a paisagem e se identifica com ela mesmo com dificuldades, provavelmente porque não associam à paisagem os problemas sociais e as dificuldades da qualidade de vida. O conceito de paisagem é ideal e não cultural.

Com relação a esses índices é interessante destacar que, no caso da escola 3, os alunos realizaram a atividade 1 observando uma paisagem repleta de residências edificadas em regime de autoconstrução, trechos de favela e casas mal acabadas e construídas em grande declive. Apesar da paisagem, do ponto de vista sócioeconômico, não ser um exemplo de qualidade de vida, os alunos apontaram a presença dos amigos, das árvores e da vida como aspectos que os relacionavam àquela paisagem, além de mais de $80 \%$ dos alunos dessa escola terem manifestado sentimentos de felicidade e alegria. 
A mesma relação de pertencimento aparece nos desenhos, pois muitos alunos inseriram nas representações o lugar onde estavam, incluindo-se nos desenhos, como na figura 27 , do aluno da escola 1 que incluiu a passarela no desenho, sendo que a passarela foi o lugar de onde todos os alunos avistaram a paisagem desenhada.

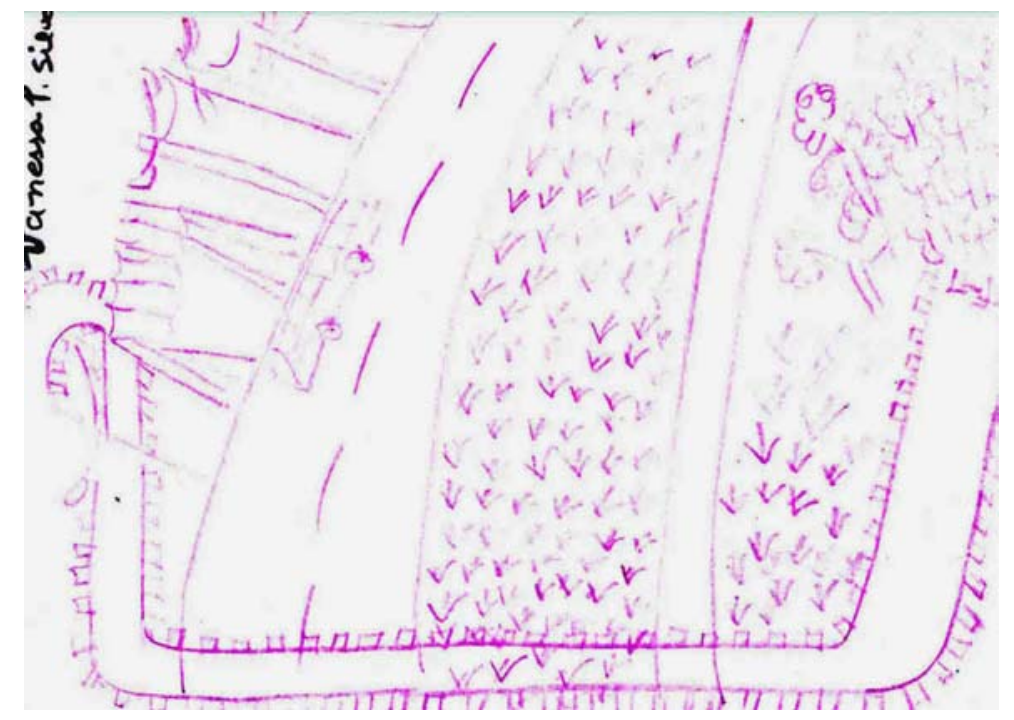

Figura 27 - Desenho da Aluna Vanessa, 20 anos, Escola 1

O inventário dos elementos da paisagem observada revelou que a maior parte dos alunos não está preparada para observar a paisagem além da sua aparência mais externa. Os elementos mais citados são as construções, edificações, árvores e veículos. Em seguida vêm as pessoas, os postes, orelhões e as vias de circulação. Raríssimas vezes houve referências ao relevo, ao solo, aos elementos do clima, aos sons, ao céu ou aos problemas sociais e às relações que se estabelecem na paisagem.

A presença do morro foi citada unicamente pelos alunos da escola 6 , de São Vicente/SP, cuja presença da Serra do Mar é bastante significativa (figura 29). No caso dos alunos da escola 3 , a inclinação do relevo da área onde está a escola e na paisagem observada pelos alunos, também era bastante significativo, mas não chamou a atenção de nenhum aluno, ao contrário de uma árvore mal tratada com 
galhos secos e poucas folhas localizada em primeiro plano, que foi o elemento principal de alguns desenhos (figura 28).

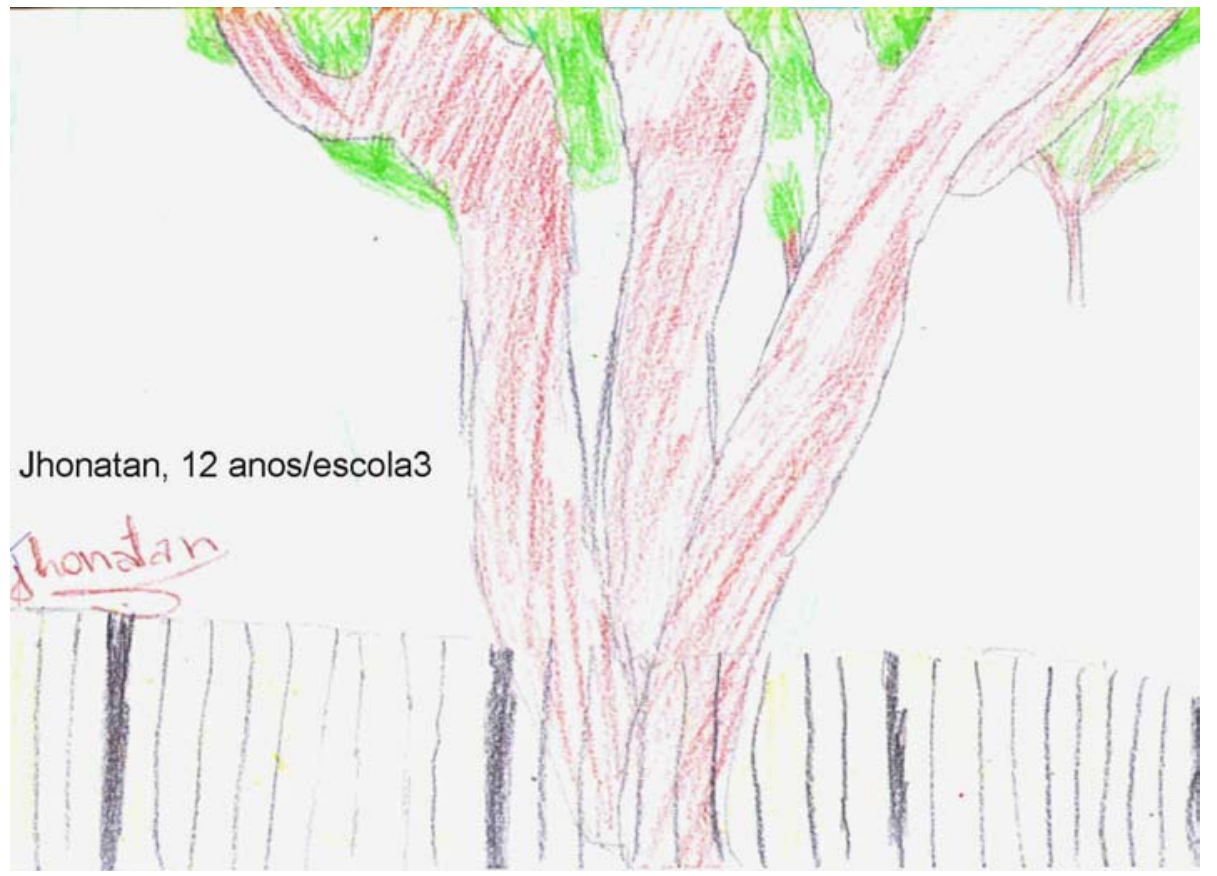

Figura 28 - Desenho do Aluno Jhonatan, 12 anos da Escola 3

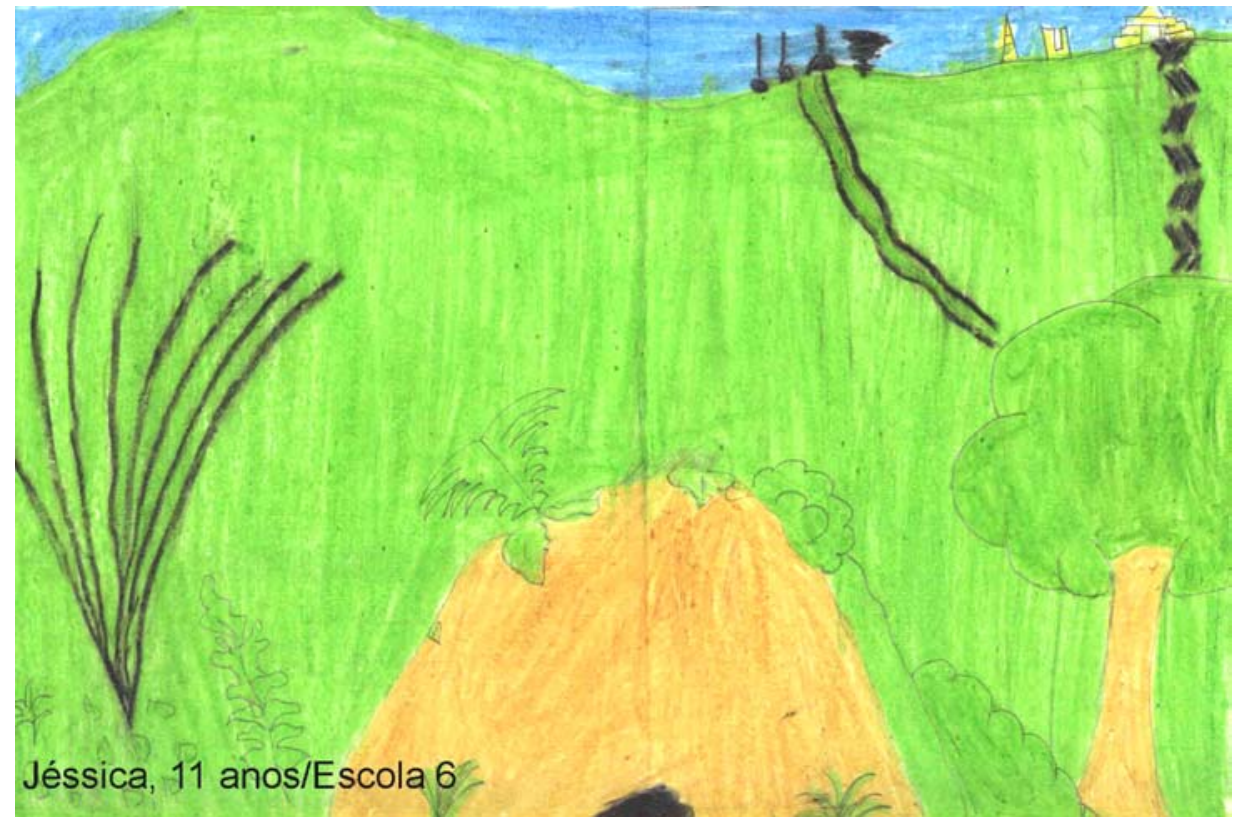

Figura 29 - Desenho da Aluna Jéssica, 11 anos da Escola 6 
A dificuldade em identificar os elementos da paisagem, além da aparência mais exterior, vai ao extremo de alguns alunos apontarem a presença de rio onde havia um lago, outro aluno identificou um sítio onde era um parque. Isso denota a fragilidade do repertório desses alunos no conteúdo básico da geografia e também a superficialidade do olhar dos mesmos.

As questões da Atividade $B$ permitiram avaliar também que uma parcela dos alunos não entende o desenho e a pintura como expressão, mas sim como ferramenta para reprodução da realidade. Como nem sempre possuem o domínio da técnica do desenho, demonstram insatisfação com o resultado. Essa insatisfação com o próprio desenho é freqüente e a palavra "tudo" aparece em torno de 17 vezes nas respostas dos alunos para representar o que eles mudariam em seus desenhos. Alguns afirmam que desenhariam uma paisagem ideal, com cachoeiras, rios, floresta, ainda que esses elementos não fizessem parte da paisagem observada. Outros alunos reafirmaram o desejo de imitar a paisagem observada nos detalhes. Pouquíssimos alunos demonstraram satisfação com o próprio desenho.

Dos oito grupos de alunos (parte 1 e parte 2 dos experimentos) somente o grupo de alunos da escola 2 (uma escola particular) demonstraram maior preparo e melhor argumentação. Os alunos dessa escola apresentaram maior intimidade com a linguagem dos quadros, já conheciam técnicas de perspectiva e também evidenciaram ter estudado o tema da paisagem anteriormente. Entretanto, o desempenho deles não se distanciou dos alunos das outras escolas, pois não se lembraram de usar a perspectiva na hora de desenhar e suas respostas escritas foram muito semelhantes às dos outros grupos.

No que diz respeito à faixa etária, os grupos de alunos mais velhos, das ONGs 7 e 8 se destacam dos demais somente no maior número de referências a problemas sociais nas suas respostas, em diferentes momentos, embora não tenha sido um número grande. Quanto aos adultos da escola 1, por se tratar de um grupo de alunos de ensino supletivo, eles apresentaram muita dificuldade na expressão 
escrita, mas um enorme empenho e dedicação apesar de se equipararem aos outros no resultado geral.

\subsection{Resultados das Atividades: Desempenho dos Alunos a Partir das Propostas Realizadas}

Na primeira etapa dos experimentos, na escola 1 foi desenvolvido um trabalho com duração de 6 horas-aulas distribuídos em 4 dias ao longo de 3 semanas, o que permitiu que os conceitos e idéias fossem trabalhados e assimilados aos poucos e também significou a construção de uma relativa amizade e intimidade com os alunos.

Por outro lado, uma intervenção de 6 horas-aulas ocasionou uma interrupção relativamente grande no trabalho que já vinha sendo desenvolvido pelo professor de Geografia, que no caso da escola 1, só possuía 3 horas-aulas de encontros, por semana, com os alunos.

Se por um lado essa experiência inicial mostrou que a necessidade de maior tempo para trabalhar com conceitos como paisagem é fundamental, por outro lado, para uma intervenção como a que foi realizada, com um professor de fora e que de certo modo "invade" a sala de aula, um certo constrangimento e a preocupação do tempo não se tornar um problema nas escolas seguintes, trouxeram a necessidade de adaptar o roteiro de atividades para que menos tempo fosse necessário à sua aplicação.

Assim, para a escola 2, o roteiro foi adaptado e desenvolvido em 4 horas-aula divididas em dois dias, com a inclusão de uma nova atividade voltada para a interpretação e comparação da paisagem rural e urbana e foram excluídas as atividades relativas à leitura e interpretação de textos e quadros, o desenho final da 
paisagem e uma parte da orientação sobre como se desenha uma paisagem. Na escola 3, o mesmo roteiro de 4 horas-aulas foi desenvolvido em uma única tarde.

Comparando-se as experiências das três escolas foi possível concluir que o recomendável para o desenvolvimento desse conjunto de atividades sobre paisagem é a utilização de, no mínimo, 6 horas-aulas distribuídas em vários dias, como foi feito na escola 1, o que permite a construção contínua das noções conceituais propostas, com uma rápida revisão do que foi realizado anteriormente a cada retomada. Do ponto de vista do professor, o intervalo entre as atividades permite, com tranqüilidade, a avaliação dos exercícios realizados e o preparo e organização das atividades seguintes com base nessa avaliação.

Apesar da recomendação para que os professores da Oficina desenvolvessem o roteiro em, pelo menos 6 horas-aulas distribuídas em mais de um dia, das cinco instituições que desenvolveram o roteiro de atividades, somente três delas o fizeram em mais de dois dias. As outras duas instituições (escola 4 e ONG 1) o fizeram em apenas um dia e de maneira incompleta. Sendo que na avaliação final, um dos alunos apontou a pressa da professora como um aspecto negativo das atividades: cansativo foi "a professora. Querendo fazer tudo p/ ontem" (Willian Araújo, 18 anos, ONG 1).

No que se refere ao tempo dedicado a cada atividade, com exceção de duas professoras que não compreenderam a questão proposta na avaliação escrita e não responderam corretamente, os professores que participaram das duas etapas de trabalho de campo foram unânimes na opinião de que o tempo sugerido para cada atividade está entre o ideal e a necessidade de ampliação em algumas atividades, variando de escola para escola. Em nenhum momento houve referência a "sobra" de tempo. Pode-se considerar que isso seja um indicativo da complexidade do conceito e o quanto é possível que ele esteja sendo subjugado nos livros didáticos e nas salas de aula. 
Considerando-se que a maior parte das atividades propostas aos alunos, solicitaram desses, muito mais reflexões superficiais e estímulos sensoriais do que acúmulo de informações objetivas, então é compreensível que, ao final de uma breve experiência realizada num curto período de tempo, os alunos apresentem dificuldade em articular coerentemente na linguagem escrita esse conjunto de experiências. Nas palavras de Tuan, "[...] é difícil articular boa parte da experiência humana, e estamos longe de encontrar artefatos que meçam satisfatoriamente a qualidade de um sentimento ou a resposta estética." (1977, p. 222)

Essa mesma dificuldade apresentou-se no momento de tabular os resultados das atividades. A forma de avaliação contínua e mais sustentada na observação, não permite a precisão dos números. Por outro lado, a avaliação escrita realizada pelos alunos também não garante a precisão dos resultados, uma vez que pudemos detectar falhas evidentes na comunicação escrita e na interpretação dos alunos quanto ao que foi solicitado.

Dessa forma, a avaliação dos resultados da experiência apresenta-se freqüentemente mesclado das observações realizadas durante os experimentos, uma vez que toda a avaliação escrita foi realizada na forma de questões abertas.

Ao final das atividades, em torno de $61 \%$ dos alunos afirmaram categoricamente que não mudaram de opinião quanto ao conceito de paisagem. Eles afirmam que continuam acreditando no mesmo conceito do início das atividades e alguns repetem as mesmas palavras do conceito dado anteriormente.

Os outros 39\%, em parte, não afirmam nada, apenas dão um conceito vago (algumas vezes repetição do anterior) ou, afirmam que a opinião mudou e apontam o novo aspecto do conceito que apreenderam.

Ao mesmo tempo em que é possível identificar que alguns alunos conseguiram delimitar melhor o conceito e ultrapassar a idéia de beleza e obrigatoriedade da 
presença de elementos naturais como condições para se ter uma paisagem, alguns incorporaram a idéia vaga de que paisagem é tudo. Eles passaram do conceito restritivo para um conceito completamente aberto: "Tudo o que vemos. Sim, pois eu pensava que paisagem era só florestas tipo uma paisagem natural." (Tatiane, 18 anos, ONG 2); "Paisagem é tudo. Mudou, antes eu achava que paisagem eram só aquilo que era bonito." (Patrícia, 12 anos, escola 2); "Eu acho que uma visão que nos temos de um lugar. minha opinião mudou, porque eu achava que era tudo." (Isabela, 12 anos, escola 2).

Por outro lado, apesar de uma parcela menor admitir uma mudança no conceito de paisagem, 98\% dos alunos afirmam ter aprendido "coisas" com as atividades. Desses, $40 \%$ relacionam o aprendizado à noção e ao sentido de paisagem, outros se referem às questões relacionadas à natureza, à capacidade de observação e olhar, à capacidade de expressão e o relacionamento com os colegas, à pintura, à arte, sobre as transformações na cidade de São Paulo, ou ainda respostas vagas como "muitas coisas" e "de tudo um pouco".

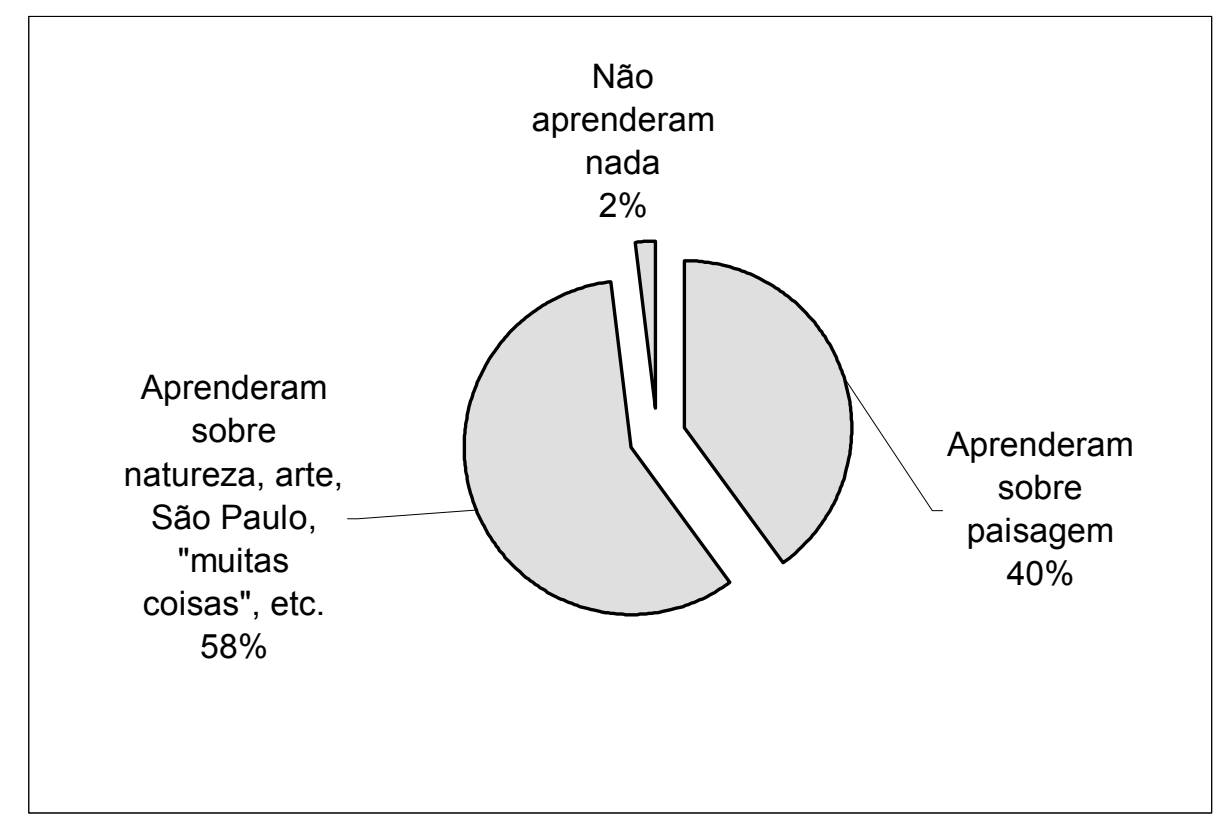

Gráfico 2 - $O$ que os Alunos Afirmam que Aprenderam 
Essas afirmações demonstram a amplitude do trabalho proposto. Um mesmo grupo de alunos, como o da ONG 1, expressou 14 itens diferentes sobre o que aprenderam, desde "Trabalhar em grupo com as amizade" (Claudia, 16 anos) até "A identificar a paisagem" (Rafael, 17 anos). Mesmo com toda a pressa da professora que era uma estudante de Turismo atuando na ONG como professora responsável pelo programa de Geografia do Projeto Aprendiz de Turismo, e, mesmo o roteiro tendo sido desenvolvido num único dia, ainda assim a avaliação dos alunos e da professora demonstra que houve uma forte sensibilização dos alunos para diversos aspectos, como arte e criatividade, geografia, relações humanas e meio ambiente.

Como afirma Tuan "quase tudo se aprende no nível do subconsciente" (1977, p. 221), sendo assim, se $98 \%$ admitem terem aprendido algo é porque aprenderam mais do que são capazes de avaliar.

Avaliando os resultados nesse nível do imponderável, a demonstração de interesse, entusiasmo e dedicação dos alunos, observada e registrada a partir da avaliação dos mesmos e dos professores é um dos resultados mais relevantes desse trabalho. Dos 148 participantes, um aluno que não havia participado de todas as atividades afirmou não ter gostado da experiência e, outro disse que detestou tudo, mas este entendeu que a pergunta era sobre o ano letivo e não sobre o roteiro de atividades. $O$ restante dos alunos são muito pontuais na crítica, destacando atividades isoladas que não gostaram mas exaltando o conjunto das atividades como muito interessantes.

Questionados sobre o que acharam mais cansativo, uma parcela dos alunos associou a palavra cansativo unicamente a esforço físico e por isso, 17\% apontaram as caminhadas que tiveram que fazer até o local de realização da observação e do desenho/pintura da atividade $A$ ou então $\mathrm{o}$ fato de terem que desenhar mal acomodados na rua. Esses alunos estão concentrados nas escolas 1, 6 e ONG 1. 


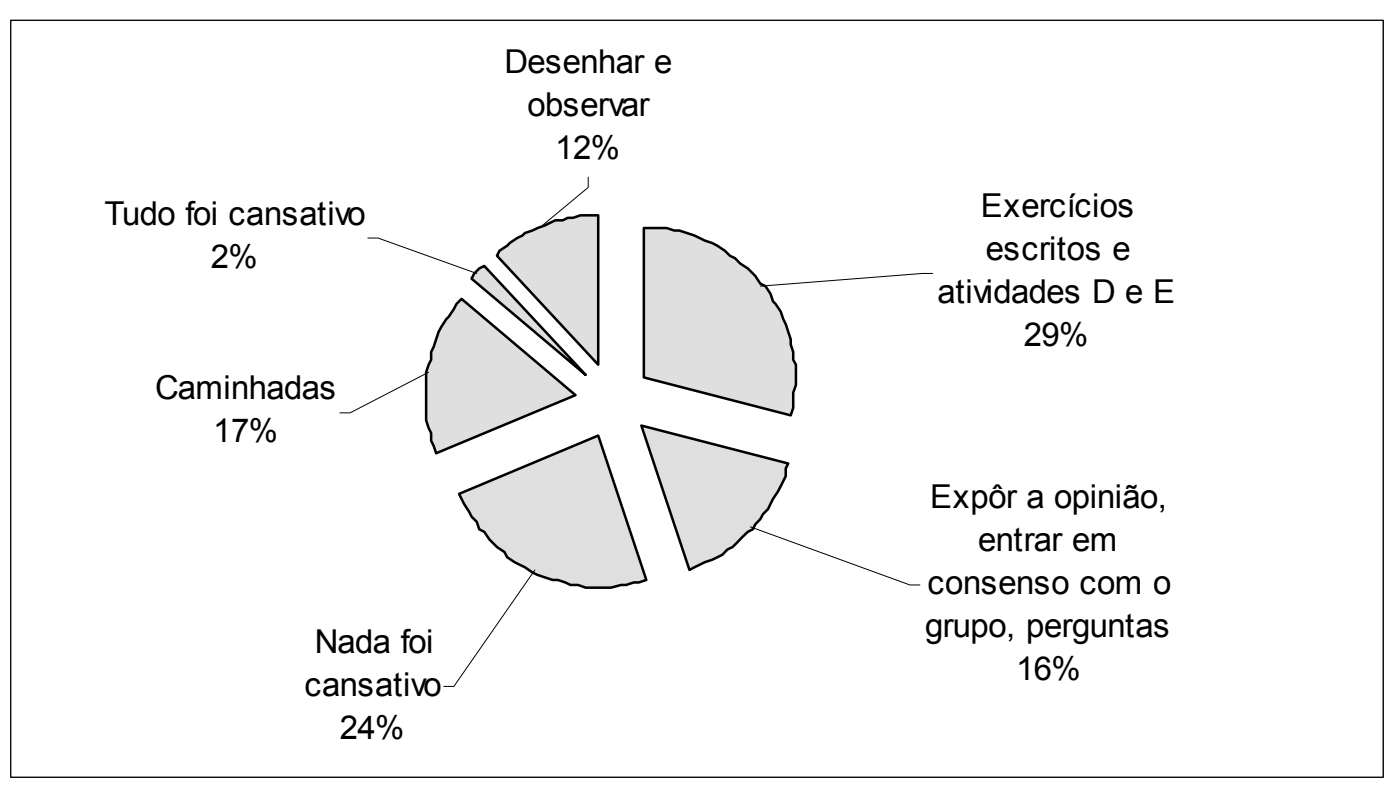

Gráfico 3 - Atividades mais Cansativas na Opinião dos Alunos

$\mathrm{Na}$ escola 1 a caminhada foi de aproximadamente 200m. Na escola 6 os alunos fizeram um percurso mais longo, passando pelo bairro Humaitá na cidade de São Vicente, pelo manguezal até chegar na "prainha" antes de voltar à escola. Na ONG 1 os alunos foram ao Parque Municipal de Barueri localizado no bairro vizinho ao da instituição a uns $2 \mathrm{~km}$.

Mas apesar do esforço físico e do cansaço de alguns, $24 \%$ do total de alunos, incluindo alunos da escola 1 e ONG 1, declararam que nada foi cansativo e que gostaram muito das atividades: "não achei nada cansativo, as aulas foram muito proveitosas" (Sheila, 25 anos, escola 1); "Não achei cansativo, pelo contrario aprendi mais com essas atividades" (Shirley, 15 anos, ONG 1); "Nada por que tudo foi legal" (Dayana, 12 anos, escola 3).

Essas respostas somadas às observações sobre o que acharam mais interessante demonstram a importância que as atividades tiveram para os alunos, enriquecendo o repertório e o conhecimento visual, ampliando a percepção e os sentidos, 
estimulando a criatividade, a imaginação e a reflexão, ainda que minimamente, se relacionarmos à superficialidade dos conteúdos abordados.

Ao contrário do entusiasmo demonstrado em relação às atividades, $29 \%$ dos alunos não gostaram dos exercícios escritos e das atividades $D$ e $E$, de construção e interpretação de overlays sobre os quadros. Ainda que uma pequena parcela tenha se referido ao desenho como cansativo, é importante ressaltar que as respostas dos alunos apontam para o desenho do overlay como sendo a atividade cansativa e não o desenho da paisagem: "pintar e passar no vegetal" (Adriana, 12 anos, escola 2). Outros justificaram não ter gostado de desenhar em razão das dificuldades que têm em dominar a técnica.

Quanto aos exercícios escritos, a desaprovação dos alunos demonstra o esgotamento dessa estratégia a que os alunos têm sido submetidos no processo ensino-aprendizagem. Ainda é mais freqüente, na escola, a adoção da linguagem verbal escrita na construção do conhecimento.

A utilização da imagem e recursos da arte na construção do conhecimento ainda é uma exceção no cotidiano desses alunos: "eu gostei muito achei muito enteressante porque foi uma aula diferente das outras" (Marineuza, 33 anos, escola 1).

Quanto às reproduções dos quadros utilizados nos exercícios, praticamente $100 \%$ dos alunos que participaram das atividades declararam que não conheciam nem os quadros nem os pintores Antônio Gomide e Agostinho Batista de Freitas. Somente um aluno disse que já ouvira falar em Antônio Gomide. E na avaliação final, em torno de $20 \%$ dos alunos apontaram os quadros e as paisagens como uma das "coisas" mais interessantes das atividades. Como, em geral, os alunos não fizeram distinção a respeito de qual paisagem estavam falando, consideramos que referiam-se aos quadros de paisagem. 
O entusiasmo relativo ao trabalho com arte, transparece também nas referências ao que aprenderam e no prazer que tiveram ao utilizar o desenho como forma de expressão. Apesar da demonstração de insatisfação com o resultado dos desenhos realizados, $46 \%$ dos alunos se referiram ao ato de desenhar como uma das atividades mais interessantes, sendo que esse valor é maior se somarmos as referências positivas encontradas nas respostas de outras questões.

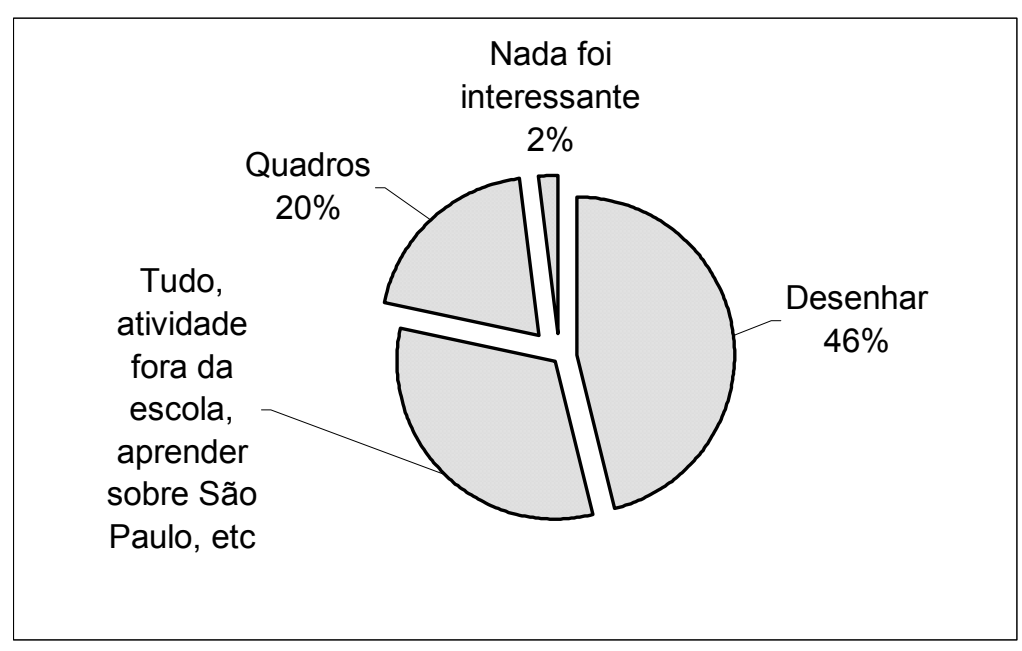

Gráfico 4 - Atividades mais Interessantes na Opinião dos Alunos

Como é possível constatar, mesmo alunos mais velhos sentiram prazer em desenhar: (mais interessante foi) "desenhar a paisagem, que foi uma coisa que ninguém tinha me proposto antes" (Iolanda, 15 anos, ONG 1); "O que eu achei mais interessante nas atividades foi desenhar e por conhecer nossos pintores e olhar que eu nao conhecia" (Daiane, 17 anos, ONG 2); "Achei mais interessante os desenhos que tivemos que fazer." (Adinilson, 28 anos, escola 1).

No conjunto das declarações dos alunos, chamou atenção o volume de referências diluídas entre as respostas das diversas perguntas, à palavra liberdade e à sensação de ser livre como categorias de valor. Como essas referências se concentraram entre os grupos que fizeram o desenho em locais fora da escola, isso reforça a idéia 
de que sair do ambiente da sala de aula para realizar um trabalho de percepção da paisagem é positivo.

O fato das três primeiras escolas não possuírem janelas com vista para a rua, a princípio pareceu uma dificuldade para a realização do trabalho de campo. Mas ao final da primeira parte dos experimentos, as observações e as declarações dos alunos demonstraram que as saídas até a rua, mesmo que fosse na porta da escola, tinham se constituído em um dos momentos mais prazerosos do roteiro de atividades.

O resultado das atividades em grupo demonstra que a observação e a comparação dos quadros Aspectos de São Paulo e Teatro Municipal, na interpretação das transformações na paisagem é válido, mas não suficiente. Muitos grupos limitaramse à descrever as mudanças de maneira simplista: "antes havia mais área verde, depois menos áreas verdes", "antes tinha menos população, depois mais população".

Poucos grupos, em alguns momentos, conseguiram articular uma comparação estabelecendo um porquê para as transformações: "A grande diferencia entre 1942 eram grandes matas Ao passar o tempo de 1985 as matas foram sumindo por causa da construção de casas, apt. e varias outras coisas" (escola 5); "Antigamente tiravam o necessário para o consumo, preservando sua flora. Hoje à grandes desmatamentos para construirem suas industrias." (ONG 1, sobre transformações na fauna).

As respostas dos alunos à atividade $F$, demonstram quanto os alunos tem dificuldade em relativizar as transformações no espaço-tempo. Um grupo de alunos identificou as casas representadas no quadro Aspectos de São Paulo como sendo pobres, pela falta de luxo, cujo referencial ele identifica nas construções atuais. 
Questionados sobre por quê a paisagem muda, as respostas são variadas, desde uma suposta evolução que inclui a paisagem, passando pelo tempo e pela tecnologia até chegar no homem. De fato, direta ou indiretamente, o homem é o elemento mais citado como o responsável pelas mudanças na paisagem embora ele não apareça como responsável pelas transformações nos meios de transportes, habitação, fauna, flora, etc.

A mesma dificuldade aparece nas respostas da questão Quem constrói a paisagem? Nesse caso, Deus aparece nas respostas de 3 dos 35 grupos, e num deles Deus é colocado como sinônimo de natureza. Na verdade os alunos explicam-se dizendo que Deus criou e o homem transforma. Somente duas vezes, aparecem as respostas "nós" e "agente", no restante dos grupos a resposta predominante é o "homem" seguido (e algumas vezes junto) da "natureza".

Essas respostas identificam a influência que alguns alunos sofrem dos chamados slogans aprendidos nas aulas de geografia, da religião e até mesmo da mídia, quando valoriza as paisagens de alguns lugares, dizendo que "Deus caprichou ali!" O homem, Deus e a natureza são entendidos como entidades poderosas e distantes dos alunos. Raramente, eles conseguiram estabelecer a relação entre homem, natureza, paisagem e eles mesmos.

Apesar dessas dificuldades entendemos que se 29 grupos (de um total de 35) atribuíram as transformações e construção das paisagens ao homem, é um sinal de que a noção do conceito de paisagem geográfica, como produto concreto do processo de modelagem física e cultural, que se constitui em marca - expressa uma civilização - e matriz - determina o olhar, a experiência... (BERQUE, 1984, p.86-86, In: CORREAA, 1998) - teve pelo menos uma noção apreendida.

No que diz respeito aos resultados das Atividades $D$ e $E$, apesar dessas atividades terem sido apontadas como cansativas pelos alunos, as observações realizadas, principalmente durante os debates da parte $E$, apontaram a atividade como 
esclarecedora das dúvidas entre paisagem rural e urbana, identificando funções dos elementos e as atividades características dessas áreas, além das relações de interdependência. Na segunda etapa dos experimentos, essas atividades foram realizadas somente na escola 5 e ONG 2 e o único registro são os overlays, pois não há mais referências a essas atividades nas avaliações dos professores e dos alunos.

De um total de 21 alunos, das escolas 1 e 5 que realizaram os dois desenhos das atividades $A$ e $H, 18$ alunos mudaram o enquadramento e a escala no segundo desenho, incluindo também mudanças na utilização de cores, formas e elementos. Os outros 3 realizaram desenhos muito semelhantes ao primeiro, com diferenças sutis na escolha das cores, mas sem mudanças significativas na representação.

Alguns alunos demonstraram capacidade para incorporar no segundo desenho as informações relativas às técnicas de perspectiva. Como pode ser observado nos dois desenhos do aluno Adinilson (Figuras 30 e 31), o primeiro desenho apresenta uma única tentativa de imprimir profundidade através do alongamento da pista. Há somente dois tons de cores e poucos elementos, apesar do equilíbrio na distribuição dos mesmos.

Entretanto, o segundo desenho incorpora a representação da profundidade nas árvores e nos edifícios ao longo da pista, utilizando-se da diminuição de elementos, enquanto o desenho da pista apresenta afunilamento da base para o fundo demonstrando a clara intenção de representar a profundidade e a curva da estrada. Quanto às cores e formas, o segundo desenho também é mais rico em detalhes e na distribuição de cores, embora o aluno tenha disposto do mesmo intervalo de tempo para realizar os dois trabalhos. 


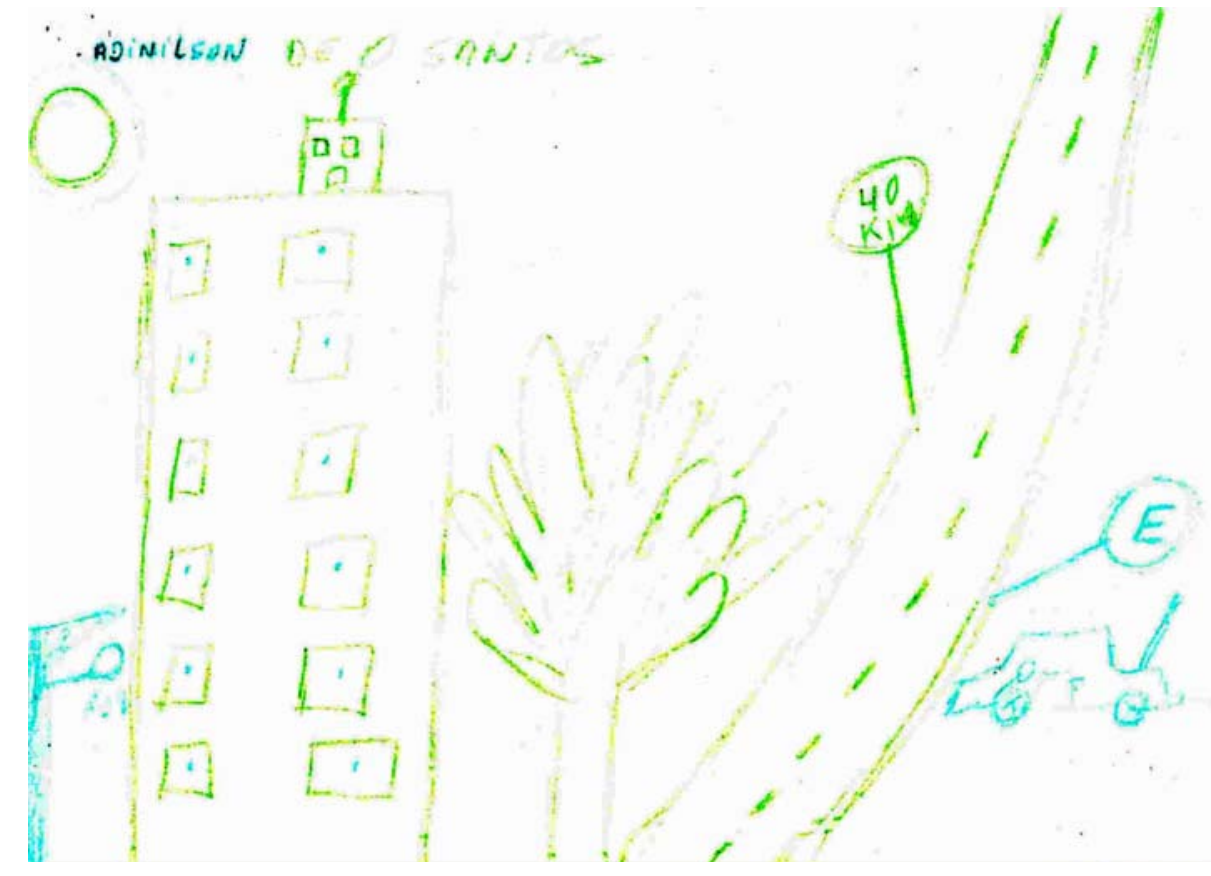

Figura 30 - Desenho 1 do Aluno Adinilson, 28 anos, Escola 1

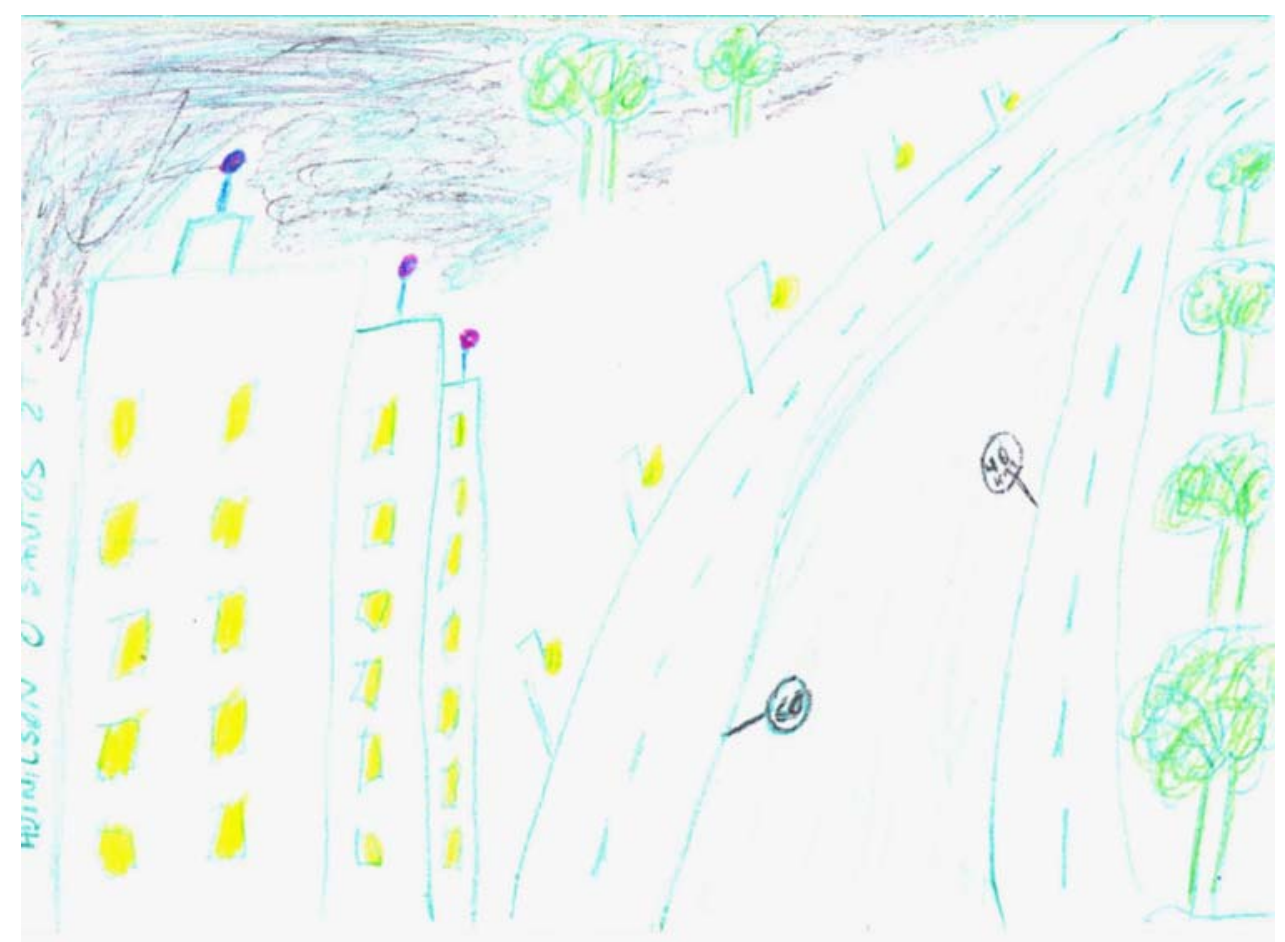

Figura 31 - Desenho 2 do Aluno Adinilson, 28 anos, Escola 1 
A foto a seguir foi tirada no local onde os alunos da escola 1 realizaram os dois desenhos. Como se pode verificar, o trabalho de observação, desenho e pintura foi todo realizado à noite. Esse detalhe que a princípio chamou a atenção do professor e da Coordenadora Pedagógica da escola 1, não incomodou nenhum aluno, pois não houve um só comentário verbal ou escrito e esse respeito, mas também, poucos alunos tiveram a preocupação de representar a noite nos desenhos.

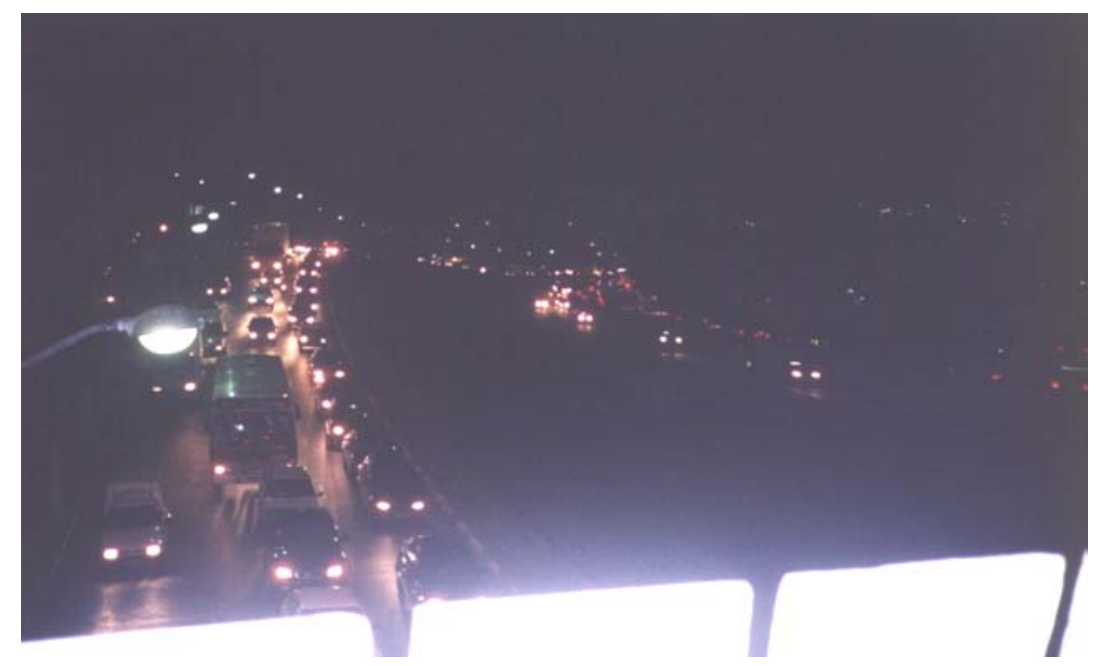

Figura 32 - Fotografia com Vista da Passarela Próxima à Escola 1

O segundo desenho do aluno Adinilson (figura 31) apresenta uma intenção de demonstrar a noite através da pintura escura do céu à esquerda. Os demais alunos pouco se ocuparam desse detalhe ou solucionaram o problema inserindo elementos simbólicos como a lua e estrelas (figura 33) 


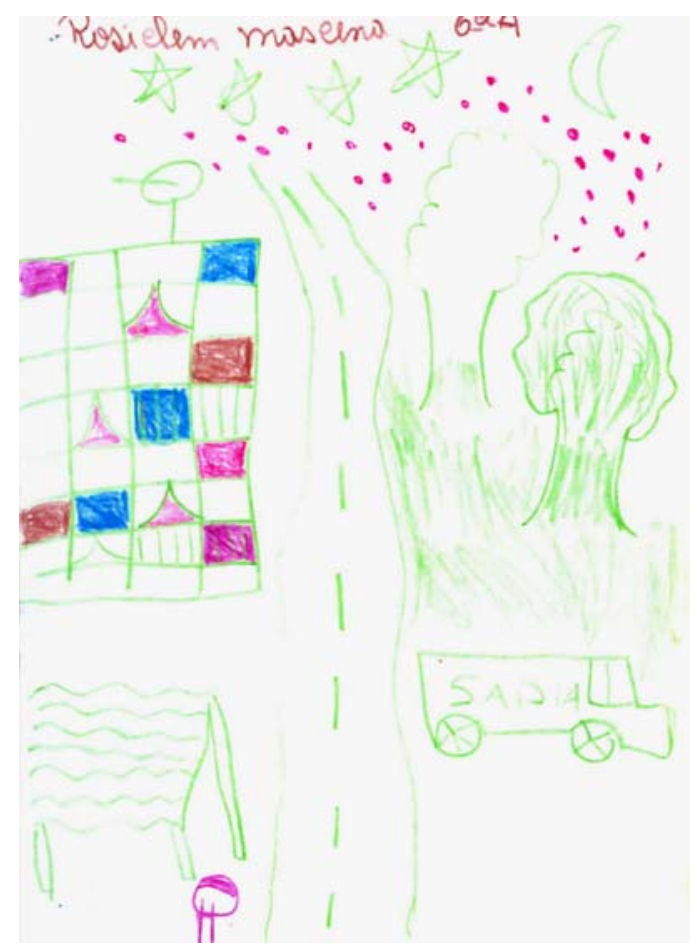

Figura 33 - Desenho da Aluna Rosiclem, 23 anos, Escola 1

Em todas as outras instituições, as atividades foram desenvolvidas durante o dia e a mesma característica se mantém: o predomínio da figura em detrimento do fundo. Da mesma forma, o olhar dos alunos para a paisagem seleciona os elementos evidentes em primeiro plano - edifícios e carros - e raramente se detém no suporte ou quadro físico, como o relevo, por exemplo.

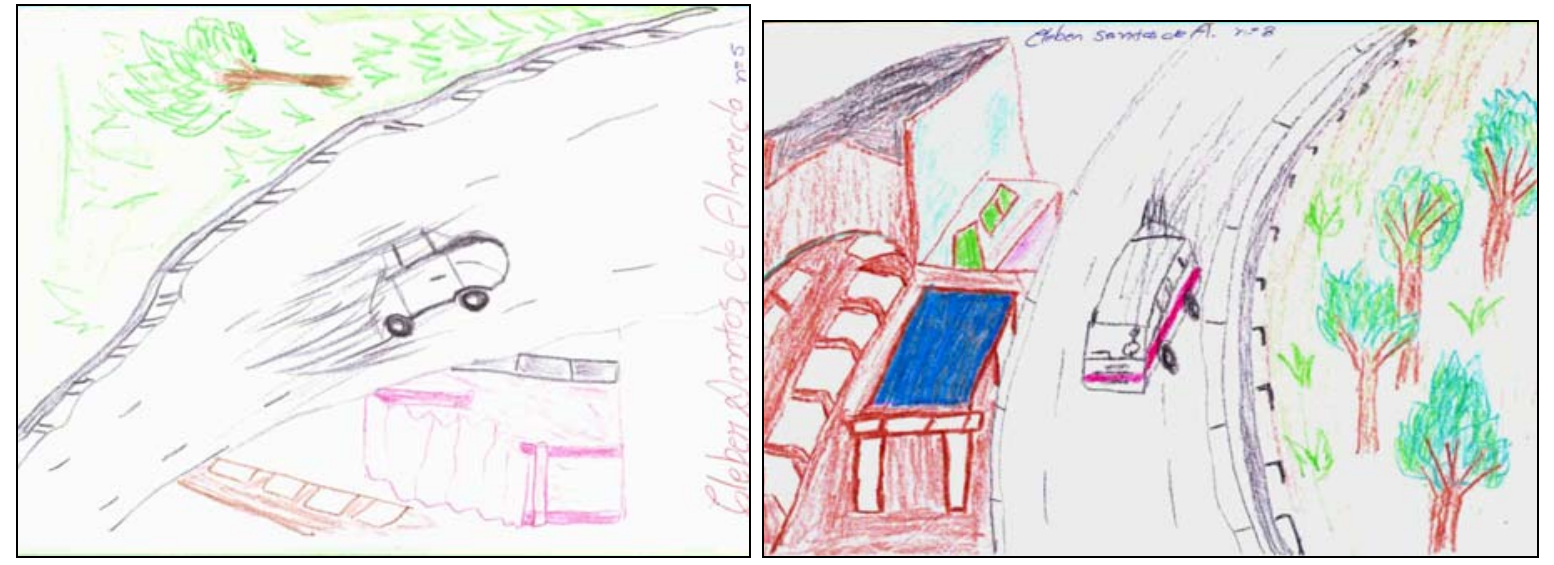

Figura 34 - Desenhos 1 e 2 do Aluno Cléber, 17 anos, Escola 1 
Outros alunos conseguiram evoluir de uma representação enumerativa (figura 35) com elementos desconectados para uma representação mais organizada, tendendo para o orgânico (figura 36), de acordo com a classificação de Read (1958) ${ }^{22}$, embora não haja um padrão na representação quanto ao ângulo de visão, pois o aluno mescla visão oblíqua com vertical.

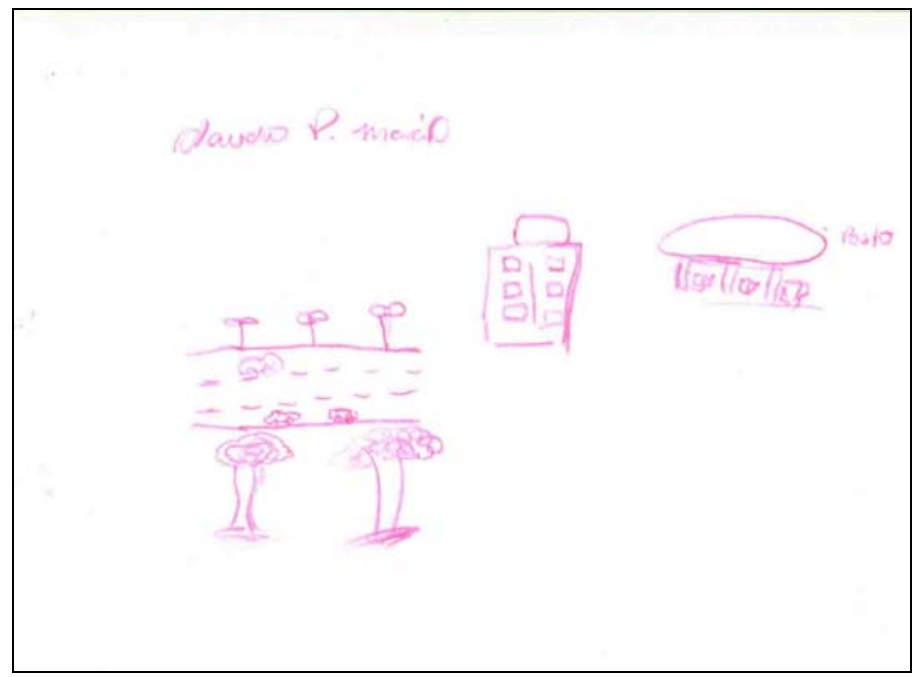

Figura 35 - Desenho 1 do Aluno Cláudio, 37 anos, Escola 1

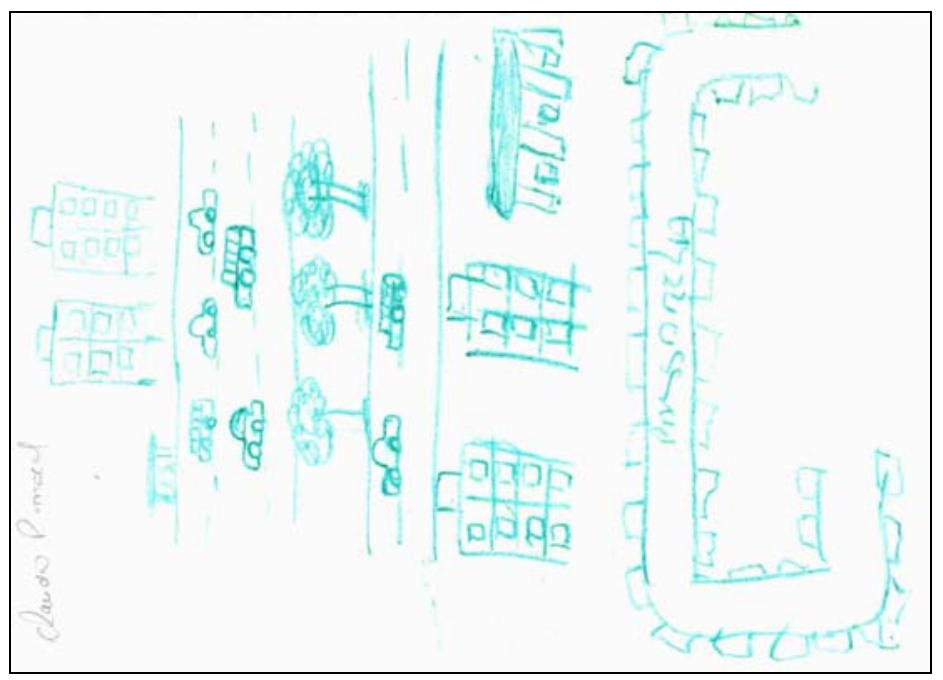

Figura 36 - Desenho 2 do Aluno Cláudio, 37 anos, Escola 1

\footnotetext{
${ }^{22}$ Herbert Read em seu trabalho A Educação pela Arte, classifica os desenhos infantis em oito categorias relacionando-as aos tipos psicológicos. São as categorias: orgânica, empatética, modelo rítmico, forma estrutural, enumerativa, háptica, decorativa e imaginativa.
} 
Alguns alunos ampliaram, no segundo desenho, o número de elementos representados na composição e também modificaram a escala da representação, como no caso dos desenhos desses alunos da escola 5:
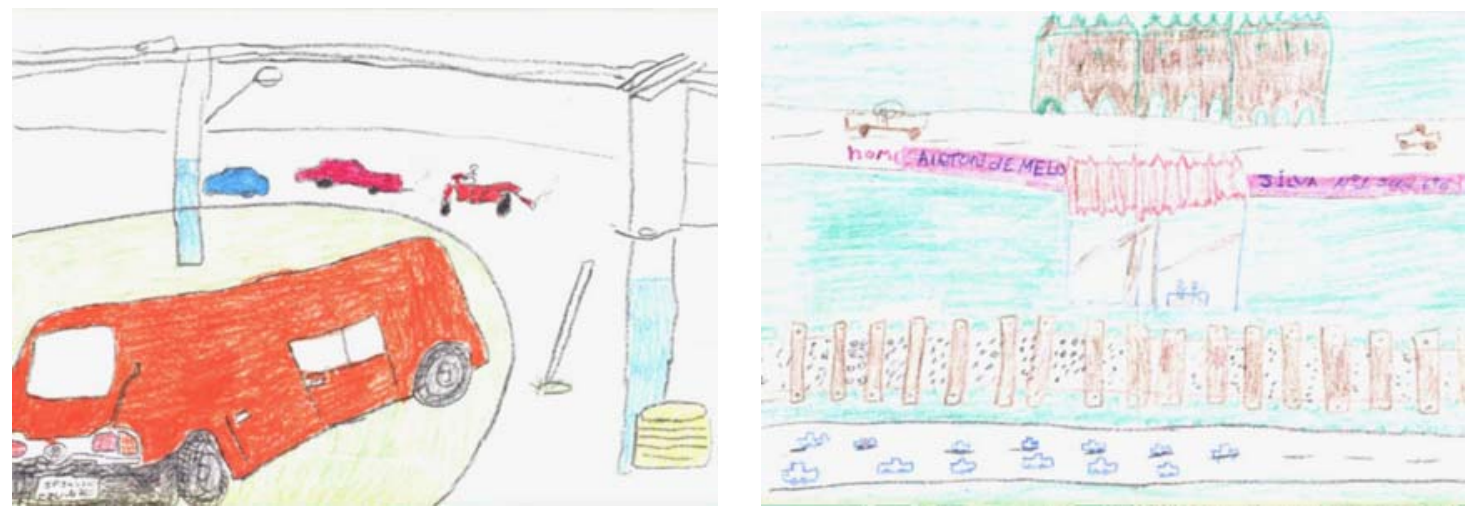

Figura 37 - Desenhos 1 e 2 do Aluno Airton, 13 anos, Escola 5
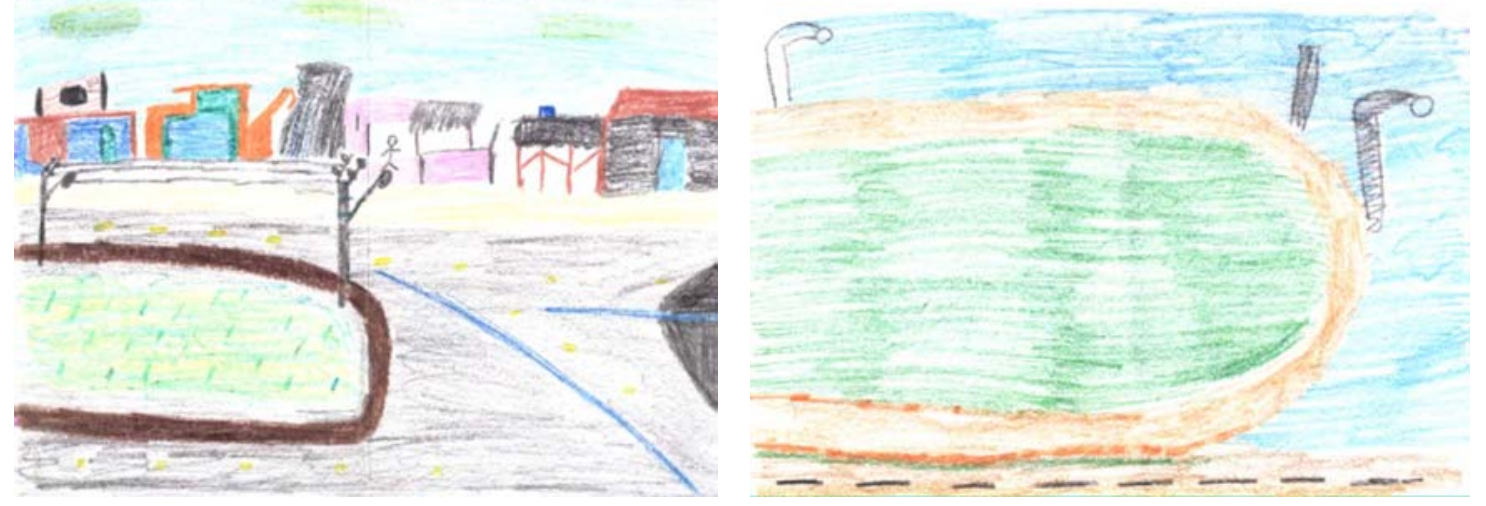

Figura 38 - Desenhos 1 e 2 da Aluna Priscila, 12 anos, Escola 5

De forma generalizada e mesmo entre os alunos mais velhos, da escola 1 e das ongs 7 e 8 , os desenhos dos alunos são bastante simbólicos, com telhados em V nas casas, Sol como circunferência com linhas perpendiculares como raios, nuvens azuis e árvores em forma compacta com cores marrom e verde (figura 39). Outro grupo de alunos mistura os ângulos de visão como na figura 36. 


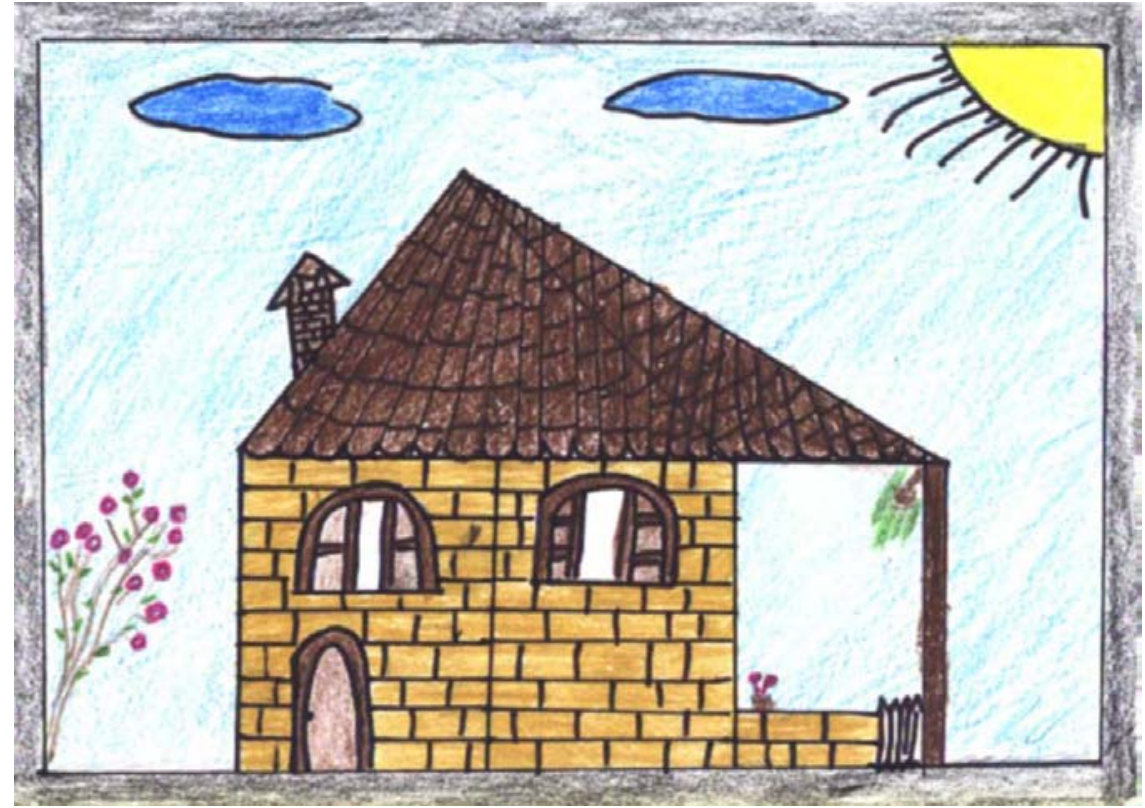

Figura 39 - Desenho da Aluna Daiane, 17 anos, ONG 8.

São poucos os alunos que conseguiram aproximar-se do realismo visual em que aparece "uma forma de desenho preocupado simultaneamente com perspectivas, proporções e medidas ou distâncias" (PIAGET \& INHELDER, 1981, p. 38) como se aproxima o desenho do aluno Roger (figura 40).

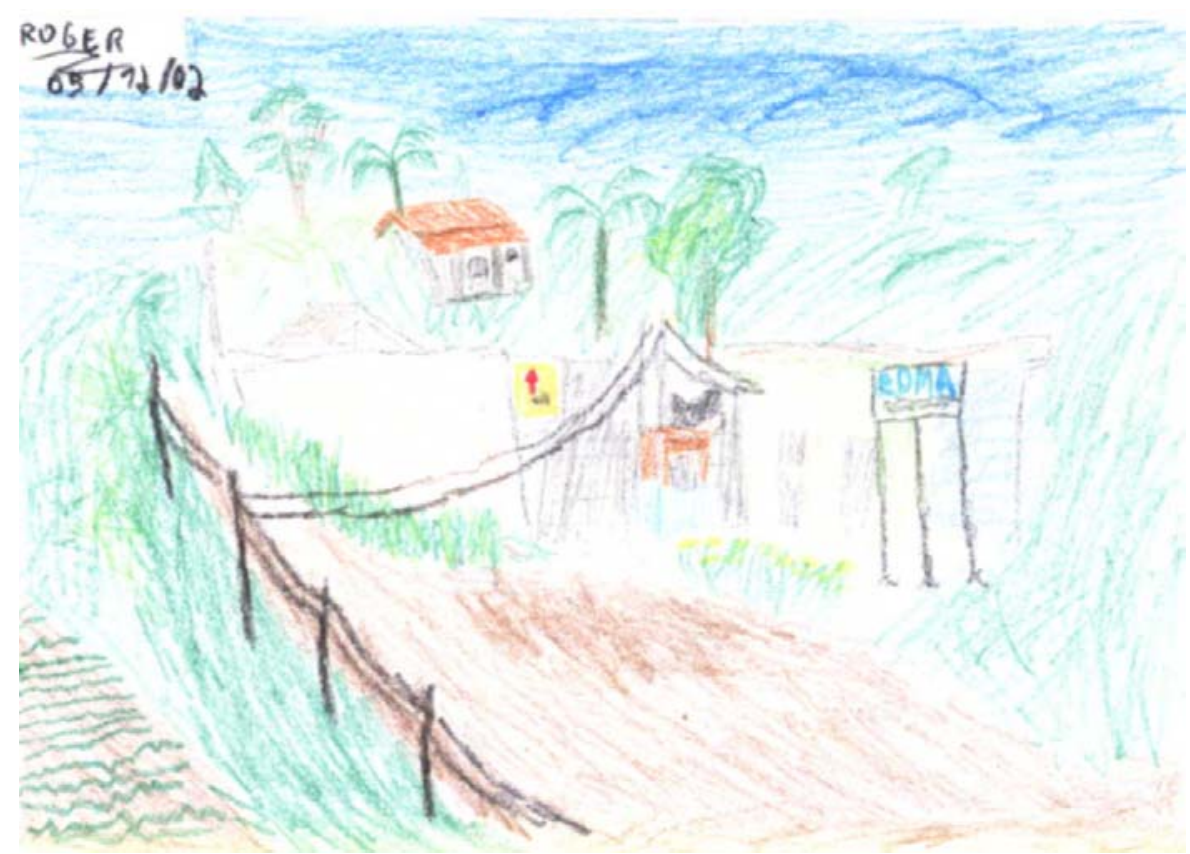

Figura 40 - Desenho do Aluno Roger, 17 anos, ONG 8 
Apesar do objetivo da proposta não ser o de transformar a arte numa cópia da natureza, sabe-se que há uma correspondência entre o realismo visual das representações e a apropriação do pensamento formal que se estrutura por volta dos 11-12 anos, a idade média dos alunos da $5^{\mathrm{a}}$ e $6^{\mathrm{a}}$ séries (PIAGET \& INHELDER, 1981, p.160). No caso dos alunos mais velhos é provável que a maior dificuldade concentre-se na habilidade técnica e não na capacidade de elaborar conceitos abstratos.

Tão viva quanto o homem, a paisagem transforma-se, seus elementos transformamse cada um numa velocidade, cada um com um grau de suscetibilidade diferente e influenciando-se mutuamente. O olhar também se transforma, detendo-se a cada evento num conjunto e num arranjo e num plano diferente. Resta compreender essas transformações mútuas.

\subsection{Avaliação dos Professores: Participação e Desempenho}

Ao final das etapas 1 e 2 dos experimentos em escolas, participaram do projeto, quatro professores de geografia, dois de artes, um de ciências, um de história e uma estudante de turismo que atua como professora na ONG de Barueri-SP. Essa combinação de profissionais de diferentes áreas resultou num conjunto de avaliações e em maneiras de conduzir o roteiro de atividades também diversas.

A participação dos professores da primeira parte do trabalho de campo foi essencial na crítica para adaptação das atividades até a organização do roteiro final. As observações e a crítica desses professores a respeito da forma de conduzir as atividades, do material, do conteúdo trabalhado, da reação e expectativa dos alunos durante as atividades foi determinante na reformulação do roteiro. 
Foi de extrema valia a participação crítica e as observações do professor de geografia das escolas 1 e 3 . Cada uma das observações feitas por esse professor foram determinantes na adaptação do roteiro, principalmente quanto à pertinência dos textos e à distribuição das atividades ao longo do tempo. A própria maneira respeitosa como o professor recebeu a participação de uma pessoa de fora em suas aulas, influenciou na forma como os alunos aceitaram positivamente a proposta de trabalho.

A participação do professor das escolas 1 e 3 foi tão intensa que ele chegou a realizar os desenhos junto com os alunos, espontaneamente, o que foi um gesto muito positivo e serviu de estímulo aos alunos.

$\mathrm{Na}$ escola 2 as atividades foram desenvolvidas intercaladamente nas aulas de geografia e história de acordo com a sugestão da coordenadora pedagógica. Contudo, como a coordenadora não teve tempo de comunicar aos professores com antecedência a intervenção, o contato com os professores se deu no mesmo momento do início das atividades. Essa forma de contato causou um certo constrangimento inicial que logo se transformou em respeito e amizade.

Ainda assim, a participação desses professores foi muito tímida. O professor de história foi bastante compreensivo e colaborou no controle da disciplina e no uso racional do tempo sem permitir que os alunos se dispersassem durante os debates em grupos. A professora de geografia foi mais participativa, provavelmente por se sentir mais à vontade para opinar na sua área de conhecimento, interferiu positivamente nos debates junto aos alunos, externalizou sua opinião a respeito da importância da multidisciplinaridade e interdisciplinaridade e fez críticas elogiosas às etapas do experimento das quais participou.

De forma geral, o projeto foi bem acolhido pelas 3 escolas da primeira etapa de experimentos, principalmente nas escolas 1 e 2 , onde o desenvolvimento do trabalho se deu durante um período mais longo. 
Os sete professores da segunda etapa dos experimentos, adotaram procedimentos divergentes do roteiro e entre si. Das cinco instituições (3 escolas municipais e duas ONGs) apenas a professora de geografia da escola 5 desenvolveu o roteiro de atividades completo. Nas demais instituições, cada professor realizou um conjunto diferente de atividades, adaptando-as e modificando-as.

Um aspecto a ser ressaltado sobre a participação dos professores durante os experimentos dessa pesquisa, relaciona-se à atitude isolada da professora da escola 4 que sustenta uma discussão relevante sobre a importância e a influência do professor na condução das atividades.

No caso da escola 4, as atividades foram conduzidas por uma professora de geografia e cabe uma avaliação do material recebido dessa escola, embora a autenticidade das respostas dos alunos possa ser questionada, uma vez que todos os exercícios individuais, em grupos e a avaliação escrita da professora foram preenchidos pela mesma pessoa (provavelmente ela própria).

A resposta de um dos alunos da escola 4 sobre o que aprendeu com as atividades revela que, em algum momento do desenvolvimento das atividades, não houve esclarecimento sobre o caráter polissêmico do conceito de paisagem, pois a resposta atribuída ao aluno foi "Aprendi que a Arte e a Geografia é a mesma coisa, tudo pode ser desenhado" (José Antônio, 10 anos, escola 4).

Outras respostas são meras cópias dos textos da atividade complementar $2, A$ paisagem geográfica na paisagem pintada, como por exemplo no item $d$ do exercício 2 que pede que o aluno identifique mudanças ocorridas na fauna da cidade de São Paulo com base na observação dos quadros 1 e 2 . A resposta, escrita e atribuída ao grupo de alunos, diz: "Muitas baratas, pardais e ratos tá cada dia menor, os animais". A letra da canção da atividade complementar 2 diz: "[...] não vá se incomodar/com a fauna urbana de São Paulo/pardais, baratas/ratos na rota de São Paulo [...]". 
Sabe-se que a atividade complementar 2 não foi desenvolvida completamente, assim como nem mesmo o roteiro completo o foi, porém se a atitude da professora se limitou a transcrever a resposta oral dos alunos, então as respostas dos alunos demonstram que o trabalho não foi desenvolvido de acordo com o proposto, e é provável que os textos selecionados para outra atividade tenham sido utilizados como consulta para a realização de um exercício cujas respostas deveriam ser espontâneas e a partir da observação dos quadros, como foi proposto.

Também a atividade complementar 1, Lendo e apreciando quadros, foi aplicada incorretamente na escola 4, pois as respostas não permitem identificar quais quadros foram analisados, os títulos atribuídos aos quadros não existem no conjunto de reproduções entregue à professora. Uma das respostas, sobre o quadro 2, contém o título "São Paulo hoje" de Antônio Gomide de 1985, sendo que o pintor faleceu em 1967. As respostas dessa atividade estavam na simples leitura do verso das reproduções dos quadros entregues à professora, bastava orientar os alunos a ler o verso das reproduções no papel.

O material recebido da escola 4, apesar de pouco volumoso, constituindo-se dos desenhos e exercícios de três alunos, chama a atenção a si mesmo e sobre a professora, em razão dos procedimentos adotados pela mesma, e reforça a idéia de que o professor é parte fundamental do processo ensino-aprendizagem.

Outro aspecto relevante relativo à atuação do professor, de forma geral, ficou explícito no trabalho realizado pela ONG 1 , em que a pessoa responsável pela condução das atividades não era professora formada, mas sim estudante de Turismo atuando como professora no Projeto Aprendiz de Turismo desenvolvido pela entidade. Sem formação específica em arte ou geografia, a professora não desenvolveu o roteiro integralmente e nem de acordo com o recomendado, contudo seu esforço apresenta vários méritos. 
Todo o trabalho foi realizado em um único dia e a atividade $D$, Paisagem e uso do solo: leitura gráfica, foi conduzida de forma que o overlay foi construído com o papel vegetal sobre o desenho dos alunos e não sobre as reproduções dos quadros. De onde se pode deduzir que não houve comparação gráfica entre o uso do solo no urbano e no rural, não sendo, portanto, realizada a discussão sobre funções da paisagem.

A idéia de realizar o overlay sobre o desenho dos alunos poderia ter sido uma alternativa criativa e proveitosa se os alunos tivessem tido a oportunidade de realizar também um desenho em área rural e pudessem compará-los, sem perder o objetivo inicial da atividade proposta. Como um único desenho - em área urbana - foi realizado pelos alunos, a atividade ficou restrita a um compromisso mecânico com a pintura, sem reflexão nenhuma sobre o uso do solo.

Por outro lado, a professora da ONG 1 dispôs-se a sair com os alunos, levando-os ao parque municipal para realizar a observação e o desenho da atividade $A$. $O$ conjunto da avaliação dos alunos demonstra que houve um debate sobre o conceito de paisagem e a importância da observação: 63\% apontaram ter aprendido sobre paisagem, observação, atenção e respeito à mesma, o restante dos alunos referiu-se a aspectos pessoais como, conhecer a si mesmo e outros.

Apesar das falhas apontadas, a professora da ONG 1 soube fazer uso do material disponibilizado (ainda que parcialmente) e soube conduzir as discussões de forma a construir sentidos, estimular a reflexão em arte e geografia, mesmo não tendo formação nessas áreas.

$\mathrm{Na}$ escola 6, o roteiro de atividades foi desenvolvido por três professores conjuntamente, a professora de artes, a professora de geografia e a professora de ciências. O roteiro desenvolvido pelas professoras afastou-se bastante do sugerido, pois o relatório e o material evidenciam a realização de um estudo do meio muito mais que um trabalho específico sobre o tema paisagem, a partir de arte. 
As professoras da escola 6 organizaram uma excursão com os alunos passando por, pelo menos, três ambientes diferentes: o bairro Humaitá, o manguezal e a "prainha" em São Vicente/SP. Em cada um desses lugares os alunos realizaram um desenho/pintura e ao voltarem para a sala de aula procederam às atividades escritas de uma só vez e numa seqüência diferente da sugerida.

A resposta do aluno Guilherme (11 anos, escola 6) à pergunta 5, Você acha que o que você viu e pintou tem alguma coisa a ver com você? Por que?, do exercício da atividade $B$ é uma boa amostra da confusão que os alunos fizeram na hora de avaliar os resultados, pois sem saber a qual paisagem tinha que se referir, o aluno explicou sua relação com mais de uma: "Se for a natureza combina comigo, o ar limpo a água limpa é ótimo, mas se for a cidade não tem nada a ver comigo a sujeira o ar poluído é muito rui".

Novamente a resposta de um aluno comprova que o roteiro de atividades não foi desenvolvido na seqüência sugerida. $O$ aluno Tiago (11 anos, escola 6), responde na primeira pergunta do mesmo exercício: "Sim Porque o que eu pintei é a realidade de uma natureza não tão preservada como uma pintura que eu vi e outra metropole em 1985 e 1942 Sendo assim o antes e depois."

Esse exercício deveria ter sido respondido logo a seguir à realização do primeiro desenho (e não depois de três desenhos diferentes) e a questão queria saber do aluno se ele entendia ter pintado ou não uma paisagem. Tudo isso muito antes dos quadros serem mostrados aos alunos e essa deveria ser a primeira vez que o aluno "ouviria" a palavra paisagem durante o desenvolvimento do roteiro. Porém a resposta do aluno demonstra claramente que no momento em que ele refletiu e respondeu essas questões, as reproduções já haviam sido mostradas e estudadas por ele, pois as datas apontadas pelo aluno se referem às datas dos quadros 1 e 2 . 
Mais uma vez, a idéia de levar os alunos a uma excursão tão ampla como a realizada só pode ser considerada como uma experiência riquíssima, porém o desenvolvimento do roteiro ficou aquém da expectativa, pois a seqüência das atividades tinha uma importância na construção dos sentidos e no desenvolvimento das idéias, o que não foi respeitado pelas professoras.

As respostas dos alunos às questões do exercício da Atividade $F$, Por que a paisagem muda?, demonstra que os alunos não realizaram a atividade a partir da observação dos quadros 1 e 2, mas sim, procurando as respostas nos textos sugeridos para a atividade complementar 2, A paisagem geográfica na paisagem pintada. Portanto, não houve observação dos quadros e as respostas não são espontâneas, são cópias de parágrafos dos textos. É por isso que 8 dos 21 alunos da escola 6 se referiram aos textos e "procurar as respostas" como a parte mais cansativa das atividades. $O$ inacreditável é que muitos conseguiram achar nos textos respostas para perguntas pessoais.

Esse descompasso entre o roteiro sugerido e as atividades realizadas na escola 6, provavelmente foi uma opção adotada pelas professoras, que diante da possibilidade de incrementar o trabalho, acabaram distorcendo alguns aspectos. $E$ isso nos faz retornar à discussão sobre a importância do professor no processo ensinoaprendizagem, cuja criatividade é valiosa mas que utilizada sem critérios acaba se perdendo. As professoras tiveram a iniciativa rara de realizar um trabalho conjunto, riquíssimo em termos de variedades de paisagens, porém, na prática realizaram outro projeto e não o proposto.

Muita crítica tem sido realizada aos livros didáticos, inclusive nessa dissertação, todavia diante do poder de decisão de um professor, um bom livro didático pode se tornar uma ameaça ao aluno e o contrário também pode acontecer, um mal livro didático pode se tornar um excelente aliado na construção do conhecimento crítico. 
Cada uma das experiências realizadas na segunda etapa do trabalho de campo desta pesquisa aponta para uma possibilidade diferente e todas elas sugerem que 0 professor é fundamental na condução do processo, seja para o sucesso do trabalho ou não.

Na ONG 2, a professora que conduziu as atividades tinha formação em artes, e foi nesse grupo que apareceu o maior número de referências aos quadros como a parte mais interessante dos trabalhos. Provavelmente porque a professora valorizou as reproduções e a interpretação das mesmas mais do que foi feito nas outras instituições.

Embora a professora tenha valorizado a linguagem plástica, o restante do roteiro não foi ignorado e sim desenvolvido com muito cuidado e respeito à seqüência de atividades propostas. A ONG 2 foi uma das duas instituições que desenvolveram o roteiro de maneira mais completa incluindo ainda a atividade complementar 1.

Ao contrário dos alunos, que afirmaram não gostar das atividades escritas, a seleção de atividades feita pelos professores da segunda parte de experimentos, parece demonstrar que eles preferem desenvolver com os alunos exatamente essas atividades.

As atividades $D, E, G$ e $H$ (referentes à construção do overlay e ao segundo desenho/pintura) não foram aplicadas em 3 das 5 instituições. Já a atividade complementar 1 (atividade escrita de leitura dos quadros) foi desenvolvida em 4 instituições, mesmo não fazendo parte do roteiro básico e que não foi desenvolvido integralmente na maioria das escolas e ONGs. Ou seja, é possível que os professores tenham tido preferência pelos exercícios escritos que não demandavam esforço de elaboração por parte deles.

As atividades $D$ e $E$ necessitavam de material específico (papel vegetal para o overlay e a reprodução colorida dos quadros), o desenho final de paisagem exigia o 
retorno ao local da observação inicial, mas a atividade complementar 1 só exigia a distribuição das folhas de exercícios. Mas como nenhum professor apontou esse tipo de dificuldade nas avaliações escritas, é possível que essa substituição de atividades e a não aplicação do roteiro por completo em 4 das 5 instituições tenha sido devida a uma falha de comunicação na Oficina ou no roteiro por escrito (apêndice A) e conseqüente incompreensão por parte dos professores.

Nenhum dos professores, participantes da segunda etapa de experimentos, teve a preocupação em adaptar as perguntas 1, 3 e 4 do exercício da atividade $B$ e a questão 4 da Avaliação Final, para a situação vivida. Todos os professores reproduziram o exercício deixando a referência à "paisagem da janela" mesmo tendo levado os alunos a parques ou áreas externas à escola para fazer o desenho.

Portanto, não é possível saber com certeza se os alunos avaliaram o que se vê da janela ou o lugar onde foram fazer observações e desenhar, na segunda parte do trabalho de campo. No caso do aluno Pedro (12 anos, da escola 6) suas respostas se referem ao que se vê da janela: "pela janela a sensação de está no céu", embora o trabalho de observação e desenhos tenha sido realizado em áreas de manguezal, à beira da praia e nas ruas do bairro, como demonstram as fotos e o relatório enviados pelas professoras. O aluno Patrício (17 anos, da ONG 1) na dúvida diz o que achou da paisagem da janela e do parque onde foi com o grupo fazer as observações e o desenho: "É um pouco feia, é melhor a do parque."

Todos os professores declararam já ter tido experiências multidisciplinares anteriores com professores de áreas diferentes da sua. Todos concordam sobre a importância da contribuição mútua que as disciplinas arte e geografia podem oferecer e todos os professores avaliaram positivamente $\mathrm{o}$ roteiro de atividades afirmando terem identificado algum tipo de mudança no interesse dos alunos.

Alguns professores apontaram o tempo reduzido para o desenvolvimento do roteiro como um aspecto negativo. Os professores da etapa 2 participaram da Oficina no 
início do mês de novembro e tiveram realmente um curto período para desenvolver o projeto antes do final do ano letivo. Porém, de maneira geral, houve uma forte demonstração de entusiasmo dos professores com o material e a proposta recebida. 


\section{Considerações Finais}

Foi possível avaliar positivamente a articulação entre arte e geografia no intuito de modificar a percepção sobre a paisagem, o resultado apurado junto aos alunos identificou uma maioria de respostas e atitudes positivas em relação à percepção da paisagem, como no comentário de Fátima (16 anos, escola 1): “...quanto mais a gente olha para a paisagem mais fica bonita".

Embora o conjunto de atividades e a forma de avaliação adotada sejam pouco enfáticos, sabemos que o olhar vê de acordo com o desígnio, o plano traçado anteriormente. Portanto, por menor ou mais curto que tenha sido o roteiro, no mínimo ele estabelece um propósito de busca na paisagem.

Essa busca na paisagem que pode se dar a partir dos mais diferentes estímulos, nesse trabalho esteve concentrada na utilização de reproduções de quadros de pintores brasileiros, porém, verificou-se que outras linguagens e estratégias podem ser utilizadas com eficiência, como por exemplo, a música que foi bem recebida pelos alunos da escola 1 ou a linguagem da informática que revelou-se bastante versátil no conjunto da trabalho.

O material em $C D$ oferecido às escolas 1 e 2 e às professoras participantes da Oficina, além de ter um custo baixíssimo pode ser aproveitado no laboratório de informática das escolas, nas aulas de Artes, de Geografia e outras áreas, seja na continuidade do estudo específico do conceito de paisagem ou para estudar outros conteúdos da Geografia que se relacionem à estrutura e função da paisagem, como 
movimentos da população, urbanização, ou ainda no estudo da história da arte brasileira, de gêneros na pintura, técnicas da pintura, textos literários descritivos, etc.

$O C D$ oferecido às escolas 1 e 2 continham apresentações com os desenhos e fotos dos alunos feitas durante a realização das atividades e quando exibidas causaram uma certa euforia e satisfação nos alunos, o que poderia se transformar numa outra etapa de desenvolvimento e construção do conceito de paisagem.

Quanto ao Museu Digital, permanece a idéia de desenvolver o projeto com maior profundidade numa oportunidade futura, uma vez que há uma demanda pelo conhecimento visual da arte brasileira e as imagens digitalizadas são de fácil acesso e manipulação oferecendo diversas alternativas de trabalho: recorte das imagens, mudança nas cores, aproximação e distanciamento no foco, fusão de imagens em mosaicos, redesenhar sobre as imagens infinitas vezes, além das vantagens de impressão e cópias em diversos tipos de papéis. A informática abre a possibilidade de ampliar as formas de exploração da paisagem em artes e geografia.

$O$ ato de olhar para a paisagem é sempre uma forma de enquadramento. É impossível capturar a paisagem sem selecionar através do olhar um recorte, um conjunto de elementos. Portanto, olhar várias vezes e cada vez com intenções diferentes, soma na percepção dessa paisagem. Daí crer na necessidade de fazer esse exercício do olhar muitas vezes, pois a cada vez há um acréscimo na construção do conceito.

Para a apropriação e construção do conhecimento, a academia usualmente faz uso da palavra escrita, para tanto é necessário um longo aprendizado da gramática, das funções da língua para dominar o código e ampliar a capacidade de apreensão. Podemos também nos apropriar e construir o conhecimento através do uso da imagem. Não necessariamente sabendo desenhar, mas "sabendo olhar", como analisa Gombrich ao afirmar que o artista utiliza-se de schematas tanto quanto as 
crianças para realizar suas representações. Ou como sabemos, toda criança aprende antes a desenhar e muito depois a ler e escrever palavras.

Apesar de nem sempre saber identificar com precisão o que aprenderam ou o que modificou no modo de pensar, a maior parte dos alunos que participaram desses experimentos acredita que houve um acréscimo na sua formação, que aprenderam "coisas" sobre a paisagem e o que é melhor, todas as respostas vem associadas a observações positivas como: "foi bom", "importante", "muito interessante" e "legal".

Esses comentários associados à observação do comportamento e demonstração de interesse dos alunos durante as atividades, permitem concluir que houve uma interferência no processo cognitivo desses alunos e também no que se refere à percepção. No que diz respeito à geografia, as diferenças entre rural e urbano foram amplamente apontadas nas respostas dos alunos como sendo um aprendizado realizado. Também no que se refere à questão da beleza e da natureza como elementos necessários à paisagem, muitos alunos compreenderam e fixaram um novo conceito de paisagem geográfica que exclui a necessidade desses itens.

Pode-se considerar que a utilização de imagens e do desenho na percepção da paisagem geográfica, no mínimo, habilita e/ou treina para a leitura de imagens mais elaboradas no estudo posterior da geografia, como as cartas, mapas, perfis, croquis, plantas baixas em escalas diversas e etc.

A repetição do desenho da paisagem ao final das atividades demonstrou que a generalização, ou seja, o caráter estrutural da paisagem que é percebido inicialmente, adquire uma sofisticação, mais detalhes vão sendo incorporados à representação plástica mesmo sem um avanço considerável na qualidade técnica do desenho. Pode-se supor que essa mesma incrementação da percepção dos detalhes ocorre no nível cognitivo e com maiores detalhamentos ainda, uma vez que a evolução da habilidade plástica na expressão tem um ritmo mais lento. 
O entusiasmo e a resposta recebida demonstram que o trabalho teve uma aceitação tal que justificaria uma ampliação da duração e distribuição de atividades ao longo do tempo, incorporando outras experiências e aprofundando as abordagens conceituais. Um exemplo foi a declaração verbal do professor da escola 1 que identificou a necessidade de levar seus alunos a um Museu de Artes como forma de complementar a curiosidade e o estímulo provocado pelo conjunto de atividades.

Outro aspecto a ressaltar foi o interesse dos alunos nas atividades de desenho em oposição às atividades de leitura e escrita, o que demonstra o desgaste ou uso pouco criativo do processo de construção do conhecimento através da palavra escrita, o que nos faz acreditar no valor e na importância da pesquisa de estratégias didáticas.

Obviamente é possível pensar e planejar muito mais experiências do que as realizadas, como por exemplo, a recriação de um dos quadros coletivamente, a criação de um grande mosaico da paisagem do entorno da escola ou ainda a montagem de uma apresentação em multimídia com os desenhos dos alunos semelhantes às que foram realizadas e entregues aos professores para serem exibidas aos alunos das escolas 1 e 2. A própria participação dos professores demonstrou que a criatividade não tem limites e que existe um potencial enorme para articular arte e geografia na sala de aula. 


\section{Bibliografia}

\subsection{Referências Bibliográficas}

ARNHEIM, Rudolf.

1954 Arte \& Percepção Visual: Uma Psicologia da Visão Criadora. Tradução de Ivone T. de Faria. São Paulo: Pioneira/Ed. da Universidade de São Paulo, 1980. (Título original: Art and Visual Perception. The New Version. The Regents of the University of California, 1954, 1974.).

ASSOCIAÇÃO BRASILEIRA DE NORMAS TÉCNICAS

1989 NBR 6024: Numeração Progressiva das Seções de um Documento. Rio de Janeiro, Agosto/1989.

ASSOCIAÇÃO BRASILEIRA DE NORMAS TÉCNICAS

1989 NBR 6027: Sumário. Rio de Janeiro, Agosto/1989.

ASSOCIAÇÃO BRASILEIRA DE NORMAS TÉCNICAS

1990 NBR 6028: Resumos. Rio de Janeiro, Maio/1990.

ASSOCIAÇÃO BRASILEIRA DE NORMAS TÉCNICAS

2002 NBR 6023: Informação e Documentação - Referências - Elaboração. Rio de Janeiro, Agosto/2002.

ASSOCIAÇÃO BRASILEIRA DE NORMAS TÉCNICAS

2002 NBR 14724: Informação e Documentação - Trabalhos Acadêmicos Apresentação. Rio de Janeiro, Agosto/2002.

ASSOCIAÇÃO BRASILEIRA DE NORMAS TÉCNICAS

2002 NBR 10520: Informação e Documentação - Citações em Documentos Apresentação. Rio de Janeiro, Agosto/2002.

BARBOSA, Pedro

1995 Metamorfoses do Real: Arte, Imaginário e Conhecimento Estético. Porto/Portugal: Edições Afrontamento. 249p.

BÉGUIN, François.

1995 Le Paysage. France: Flammarion. 
BOLÓS, Maria de (org.)

1992 Manual de Ciencia del Paisaje: Teoria, métodos y aplicaciones. Barcelona: Masson, S. A.

BRASIL, Congresso Nacional

1996 Lei de Diretrizes e Bases da Educação Nacional - Lei no 9394/96 de 20 de dezembro de 1996.

BRASIL, Secretaria de Educação Fundamental

1998 Parâmetros Curriculares Nacionais $-5^{a}$ a $8^{a}$ série: Geografia. Brasília: MEC/SEF.

BRASIL, Secretaria de Educação Fundamental

1998 Parâmetros Curriculares Nacionais - $5^{a}$ a $8^{a}$ série: Arte. Brasília: MEC/SEF.

CARDOSO, Maria Eduarda Garcia

1999 O Conceito de Paisagem no Livro Didático e suas Implicações para o Ensino de Geografia. Dissertação (Mestrado) - Departamento de Geografia da Faculdade de Filosofia, Letras e Ciências Humanas da Universidade de São Paulo, São Paulo.

CAVALCANTI, Lana de Souza

1996 A Construção de Conceitos Geográficos no Ensino - Uma Análise de Conhecimentos Geográficos em Alunos de $5^{a}$ e $6^{a}$ Série do Ensino Fundamental. 258 p. Tese (Doutorado) - Departamento de Geografia da Faculdade de Filosofia, Letras e Ciências Humanas da Universidade de São Paulo, São Paulo.

CLARK, Kenneth

1949 Paisagem na Arte. Tradução de Rijo de Almeida. Lisboa: Editora Ulisseia; 1961. (Título original: Landscape into Art. Penguin Books Ltd., Harmondsworth, Middlesex.)

CLAVAL, Paul

1995 A Geografia Cultural. Tradução de Luiz F. Pimenta e Margareth C. A. Pimenta. Florianópolis: Editora da UFSC, 1999. (Título original: La Géographie Culturelle, Paris, Editions NATHAN)

CORRÊA, Roberto Lobato \& ROSENDAHL, Zeny (Orgs.)

1998 Paisagem, Tempo e Cultura. Rio de Janeiro: EdUERJ. Série Geografia Cultural, $\mathrm{n}^{\circ} 2$.

CORRÊA, Roberto Lobato \& ROSENDAHL, Zeny (Orgs.)

2000a Geografia Cultural: Um Século (1). Rio de Janeiro: EdUERJ. Série Geografia Cultural $n^{\circ} 5$. 
CORRÊA, Roberto Lobato \& ROSENDAHL, Zeny (Orgs.)

2000b Geografia Cultural: Um Século (2). Rio de Janeiro: EdUERJ. Série Geografia Cultural $n^{\circ} 6$.

DANIELS, Stephen \& COSGROVE, Denis

1988 Introduction: Iconography and Landscape. In: The Iconography of Landscape. Great Britain: Cambridge University Press, p. 1-10, 1994.

ECO, Umberto

1977 Como se Faz uma Tese. Tradução de Gilson César Cardoso de Souza. $15^{\mathrm{a}}$ ed. São Paulo: Editora Perspectiva S. A, 1999. (Título original: Como se fa una tesi di laurea, Casa Editrice Valentino Bompiani \& C. S. p. A.)

FERRAZ, Cláudio Benito O.

2001 Geografia e Paisagem: Entre o Olhar e o Pensar. Tese (Doutoramento) Departamento de Geografia, Faculdade de Filosofia, Letras e Ciências Humanas da Universidade de São Paulo, São Paulo, 394 p.

FORGUS, Ronald $\mathrm{H}$.

1966 Percepção: O Processo Básico do Desenvolvimento Cognitivo. Tradução de Nilce P. Mejias. São Paulo: Editora Herder/Editora Universidade de Brasília/Editora da Universidade de São Paulo, 1971, 528p. (Título original: Perception - The basic process in cognitive development. New York, EUA, McGraw-Hill Book Company.)

FULLER, Peter

1988 The Geography of Mother Nature. In: The Iconography of Landscape. Great Britain: Cambridge University Press, p. 11-31, 1994.

GOMBRICH, Ernst Hans.

1959 Arte e llusão: Um Estudo da Psicologia da Representação Pictórica. Tradução de Raul de Sá Barbosa. $3^{\mathrm{a}}$ ed. São Paulo: Livraria Martins Fontes Editora Ltda; 1985. (Título original: Art and Illusion - A Study in the Psychology of Pictorial Representation. The Trustees of National Gallery of Art Washington-D.C. - The A. W. Mellon Lectures in the Fine Arts.)

GOMBRICH, Ernst Hans.

1972 A História da Arte. Tradução de Álvaro Cabral. $4^{\text {a }}$ ed. Rio de Janeiro: Zahar Editores; 1985. (Título original: The Story of Art. Phaidon Press Limited, Oxford, Inglaterra)

GONTHIER-COHEN, Jöelle.

1987 Le dessin, ça Sert Aussi à Faire la Géographie, et Reciproquement. Hérodote: Revue de Gégraphie et de Géopolitique, Paris, $n^{\circ}$ 44, p. 51-65, janv-mars 1987. 
HÉRODOTE: REVUE DE GÉOGRAPHIE ET DE GÉOPOLITIQUE

1987 Paysages en Action: Le Rivage des Syrtes? n 44, p. 66, Paris, janviermars.

LACOSTE, Yves

1987 Paysages en Action. Hérodote: Revue de Géographie et de Géopolitique, Paris, $n^{\circ} 44$, p. 3-7, janv-mars 1987. Editorial.

LEITE, Maria Ângela Faggin Pereira

1994 Destruição ou Desconstrução? Questões da Paisagem e Tendências de Regionalização. São Paulo: Editora Hucitec/FAPESP.

MACHADO, Nílson José

1993 Informática nas Escolas: muito além do "sim e do não". Revista São Paulo em Perspectiva. São Paulo: Fundação SEADE, Vol 7, n 1, p. 98-105, janmar, 1993.

OLIEVENSTEIN, Claude \& LAPLANTINE, François

1993 Um Olhar Francês Sobre São Paulo. Tradução de Maria Carneiro da Cunha. São Paulo: Editora Brasiliense. (Título original: São Paulo vu par deux françois)

PEIXOTO, Nelson Brissac.

1996 Paisagens Urbanas. São Paulo: Editora Senac/Editora Marca D’Água.

PIAGET, Jean \& INHELDER, Bärbel

1981 A Representação do Espaço na Criança. Tradução de Bernardina Machado de Albuquerque. Porto Alegre: Artes Médicas, 1993 (Título original: La Représentation de l'Espace chez l'Enfant. Paris: Presses Universitaires de France)

READ, Herbert

1958 A Educação pela Arte. Tradução de Ana Maria Rabaça e Luis Felipe Silva Teixeira. São Paulo: Livraria Martins Fontes Editora Ltda. (Título original:

Education through Art)

RIOU, Gérard

1986 Les Representations de la Nature: sur les Chemins Parallèles de l'Esthétique et de la Connaissance. In: CHATELIN, Y. \& RIOU, G. (Orgs.) Milieux et Paysages: Essai sur Diverses Modalites de Connaissance. Revue Recherches en Géographie. Paris: Masson.

ROGER, Alain.

2000 La Naissance du Paysage en Occident. In: SALGUEIRO, Heliana Angotti. (Coord.) Paisagem e Arte: A Invenção da Natureza, a Evolução do Olhar. São Paulo: CBHA/CNPq/FAPESP, 2000. (I Colóquio Internacional de História da Arte CBHA-ClHA. São Paulo, 05 a 10/09/1999.) 
ROSENDAHL, Zeny \& CORREAA, Roberto Lobato (Orgs.)

1999 Manifestações da Cultura no Espaço. Rio de Janeiro: EdUERJ. Série Geografia Cultural $n^{\circ} 4$.

ROSENDAHL, Zeny \& CORREAA, Roberto Lobato (Orgs.)

2001a Matrizes da Geografia Cultural. Rio de Janeiro: EdUERJ. Série Geografia Cultural $n^{\circ} 7$.

ROUGERIE, Gabriel \& BEROUTCHACHVILI, Nicolas.

1991 Géosystèmes et Paysages - Bilan et Méthodes. Paris: Armand Colin Éditeur.

SALGUEIRO, Heliana Angotti. (Coord.)

2000 Paisagem e Arte: A Invenção da Natureza, a Evolução do Olhar. São Paulo: $\mathrm{CBHA} / \mathrm{CNPq} / \mathrm{FAPESP}$. (I Colóquio Internacional de História da Arte CBHA-CIHA. São Paulo, 05 a 10/09/1999.)

SANTOS, Milton (com a colaboração de Denise Elias)

1988 Metamorfoses do Espaço Habitado. $4^{\text {a }}$ ed. São Paulo: Editora Hucitec, 1996.

SAUTTER, Gilles

1980 Léonard de Vinci, Théoricien du Paysage. Hérodote: Revue de Géographie et de Géopolitique, Paris, nº 44, p. 106-125, janv-mars 1987.

TUAN, Yi-Fu

1974 Topofilia: Um Estudo da Percepção, Atitudes e Valores do Meio Ambiente. Tradução de Lívia de Oliveira. São Paulo: Difel/Difusão Editorial S. A., 1980. (Título original: Topophilia: A Study of Environmental Perception, Attitudes, and Values, by Prentice-Hall Inc., Englewood Cliffs, New Jersey).

TUAN, Yi-Fu

1977 Espaço e Lugar: A Perspectiva da Experiência. Tradução de Lívia de Oliveira. São Paulo: DIFEL Difusão Editorial S. A., 1983. (Título original: Space and Place: The Perspective of Experience, University of Minnesota). 


\subsection{Bibliografia Complementar}

A Musa da Parede

2001 Revista Kalunga. São Paulo, ano XXVII, n 121, p.125-127, fev. 2001.

ANDRADE, José Roberto de

2000 O Modernista Esquecido. Folha de São Paulo, São Paulo, 19 mar. 2000. Caderno Mais.

AUMONT, Jacques

1990 A Imagem. Tradução de Estela dos Santos Abreu e Cláudio César Santoro. $2^{\mathrm{a}}$ ed. São Paulo: Papirus Editora, 1995. (Título original: L'Image. Éditions Nathan)

BARBOSA, Ana Mae T. B.

1978 Arte-Educação no Brasil: das Origens ao Modernismo. São Paulo: Editora Perspectiva S. A.

BARBOSA, Ana Mae Tavares Bastos (Org.)

1997 Arte-Educação: Leitura no Subsolo. $2^{\mathrm{a}}$ ed. revista. São Paulo: Cortez Editora, 1999.

BARROS, Anna

1998 Espaço, Lugar e Local. Revista Usp, São Paulo, n 40, dez/fev 1998-99, p.32-45.

BELL, Simon

1999 Landscape: Pattern, Perception and Process. London: E\&FN Spon.

BOESCH, Hans \& CAROL, Hans

1956 Princípios do Conceito de "Paisagem". Tradução de Joaquim Q. Franca. Rio de Janeiro: IBGE. Boletim Geográfico, no 202, ano 27, jan/fev, p. 2629, 1968. (Fonte: Compte Rendu du XVIII Congrès International de Géographie, Rio de Janeiro, Union Gégraphique International)

BOSI, Alfredo

1985 Reflexões sobre a Arte. São Paulo: Editora Ática.

BRASIL, Secretaria de Educação Fundamental

1997 Parâmetros Curriculares Nacionais - $1^{a}$ a $4^{a}$ série: História, Geografia. Brasília: MEC/SEF.

BUORO, Anamelia Bueno

1996 O Olhar em Construção: Uma Experiência de Ensino e Aprendizagem da Arte na Escola. $4^{\mathrm{a}}$ ed. São Paulo: Cortez, 2000, 160 p. 
BUORO, Anamelia Bueno

2002 Olhos que Pintam: A Leitura da Imagem e o Ensino da Arte. São Paulo: Educ/FAPESP/Cortez.

CASTRO, Josué de

1966 Ensaios de Geografia Humana. 4a ed. São Paulo: Editora Brasiliense.

CASTROGIOVANNI, Antonio Carlos \& GOULART, Ligia Beatriz

1990 Uma Contribuição à Reflexão do Ensino de Geografia: A Noção da Espacialidade e o Estudo da Natureza. In: Geografia: Pesquisa e Prática Social. Revista Terra Livre, $n^{\circ} 7$, São Paulo: AGB/Editora Marco Zero.

CASTROGIOVANNI, Antonio Carlos (Org.) et al

2000 Ensino de Geografia: Práticas e Textualizações no Cotidiano. Porto Alegre: Editora Mediação.

CHRISTOFOLETTI, Antonio (Org.)

1982 Perspectivas da Geografia. São Paulo: DIFEL-Difusão Editorial S.A.

COHEN, Sylvie

1987 Points de vue sur les paysages. Hérodote: Revue de Géographie et de Géopolitique, Paris, janvier-mars 1987, p. 38-44.

CORRÊA, Roberto Lobato

1997 Trajetórias Geográficas. Rio de Janeiro: Bertrand Brasil.

COSTA, Cristina

1999 Questões de Arte: A Natureza do Belo, da Pecepção e do Prazer Estético. São Paulo: Editora Moderna. Coleção Polêmica.

COSTELA, Antonio F.

1997 Para Apreciar a Arte: Roteiro Didático. Ed. rev. e ampl. São Paulo: Editora SENAC São Paulo; Campos do Jordão, SP: Editora Mantiqueira.

DANSEREAU, Pierre

1999 A Terra dos Homens e a Paisagem Interior. Belém: UFPA/NAEA.

DAY, Ross Henry

[19--?] Psicologia da Percepção. Tradução do Departamento de Psicologia Educacional, Faculdade de Filosofia, Ciências e Letras, Universidade de São Paulo. Rio de Janeiro: Livraria José Olympio Editora e Editora da Universidade de São Paulo, [1900--?] (Título original: Perception, lowa: Wm C. Brow Company Publishers).

DEL RIO, Vicente \& OLIVEIRA, Lívia de (Orgs.)

1999 Percepção Ambiental: A Experiência Brasileira. $2^{a}$ ed. São Paulo: Studio Nobel. 
DI CAVALCANTI, Emiliano

1968 Coleção Gênios da Pintura. São Paulo: Abril Cultural.

DUARTE Jr., João-Francisco.

1994 Por que Arte-Educação? $7^{\mathrm{a}}$ ed. Campinas/SP: Papirus. Coleção Ágere, 85 p.

DUARTE Jr., João-Francisco

1995 Fundamentos Estéticos da Educação. $4^{\text {a }}$ ed. Campinas, SP: Papirus.

FABRIS, Annateresa

1996 Cândido Portinari. São Paulo: Editora da Universidade de São Paulo. Artistas Brasileiros 4.

FERRAZ, Maria H. C. T. \& FUSARI, Maria F. R.

1991 Metodologia do Ensino de Arte. $2^{\mathrm{a}}$ ed. São Paulo: Cortez Editora, 1999. Coleção Magistério $2^{\circ}$ Grau: Série Formação do Professor.

FREIRE, Cristina

1997 Além dos Mapas: Os Monumentos no Imaginário Urbano Contemporâneo. São Paulo: SESC: Annablume.

FUNDAÇÃO FINAMBRÁS

[199?] Tarsila do Amaral - Projeto Cultural Artistas do Mercosul. Buenos Aires/Argentina: Finambrás.

FUSARI, Maria F. de Rezende e \& FERRAZ, Maria Heloísa C. de T.

1993 Arte na Educação Escolar. São Paulo: Cortez Editora. Coleção Magistério $2^{\circ}$ grau. Série Formação Geral.

GIBSON, James J.

1950 La Percepción del Mundo Visual. Buenos Aires: Ediciones Infinito, 1974. (Título original: The Perception of the Visual World, Houghton Mifflin Company, Boston)

GREENBERG, Clement

1961 Arte e Cultura. Tradução de Otacílio Nunes. São Paulo: Editora Ática, 1996 - Série Temas, vol 60. (Título original: Art and Culture, Beacon Press, Boston)

HAESBAERT, Rogério.

2002 Territórios Alternativos. São Paulo: Editora Contexto/EdUFF. 
HEGEL, G. W. F.

1835 Introducción a la Estética. $2^{\mathrm{a}}$ ed. Tradução de Ricardo Mazo Barcelona: Ediciones Península, 1973. (Título original: Verlag von Duncker und Humblot, Berlín)

HILGARD, Ernest R.

1956 Teorias da Aprendizagem. $2^{\mathrm{a}}$ ed. Tradução de Nilce P. Mejias e Hilda A. Guedes e Clea A. Rameh. São Paulo: Editora Herder/Editora da Universidade de São Paulo, 1972. (Título original: Theories of Learning, Appleton-Century-Crofts, Inc., New York.)

INSTITUTO CULTURAL ITAÚ (Ed.)

1995 Gêneros na Pintura. São Paulo: ICl, 39 p. Cadernos História da Pintura no Brasil, 8.

JAPIASSU, Hilton \& MARCONDES, Danilo

1989 Dicionário Básico de Filosofia. $3^{\text {a }}$ ed. revista e ampliada. Rio de Janeiro: Jorge Zahar Editor, 1999.

LA TAILLE, Yves de; OLIVEIRA, Marta K. \& DANTAS, Heloysa

1992 Piaget, Vygotsky, Wallon: Teorias Psicogenéticas em Discussão. São Paulo: Summus Editorial.

LYNCH, Kevin

1960 A Imagem da Cidade. São Paulo: Editora Martins Fontes, 1980.

MARCONDES, B.; MENEZES, G. \& TOSHIMITSU, Thaís

2000 Como Usar Outras Linguagens na Sala de Aula. São Paulo: Editora Contexto.

MIRANDA, Maria Inês et al

1999 Transdiciplinaridade: o Desafio de Inovar. Revista Comunicação e Educação. São Paulo: Editora Moderna , no 14, jan/abr 1999, p. 33-41.

MORAES, Antonio Carlos Robert Moraes

1983 Geografia: Pequena História Crítica. 6a ed. São Paulo: Editora Hucitec, 1987.

MOREIRA, Rui

1981 O que é Geografia. $7^{a}$ ed. São Paulo: Editora Brasiliense, 1986. Coleção Primeiros Passos.

OLIVEIRA, Lívia de

1977 Contribuição dos Estudos Cognitivos à Percepção Geográfica. Geografia. 2(3), p. 61-72, abr 1977. 
PAGANELLI, Tomoko lyda.

1998 Paisagem, uma Decifração do Espaço-Tempo Social - As Representações da Paisagem da Cidade do Rio de Janeiro. Tese (Doutorado) - Departamento de Geografia da Faculdade de Filosofia, Letras e Ciências Humanas da Universidade de São Paulo, São Paulo.

PENTEADO, Heloísa Dupas

1990 Metodologia do Ensino de História e Geografia. São Paulo: Cortez Editora, 1994. Coleção Magistério $2^{\circ}$ Grau: Série Formação do Professor.

PIMENTA, Ângela Maria

1999 Aprendendo a "Olhar" a Paisagem Latino-Americana - Arte e Ambiência na Relação Indivíduo-Natureza Pesquisa-Ação em São Paulo e Santiago do Chile. Dissertação (Mestrado) - Prolam-Programa de Pós-Graduação em Integração da América Latina da Universidade de São Paulo, São Paulo.

PONTUSCHKA, Nídia Nacib

1992 Licenciandos de Geografia e as Representações sobre o "Ser Professor". Geografia, Política e Cidadania, Revista Terra Livre, São Paulo: AGB, ${ }^{\circ}$ 11-12, p. 189-207, ago/92-ago/93.

PONTUSCHKA, Nídia Nacib (Org.)

1993 Ousadia no Diálogo: Interdisciplinaridade na Escola Pública. São Paulo: Edições Loyola. Série Práticas Pedagógicas, 5.

PREFEITURA DO MUNICÍPIO DE SÃO PAULO

[1996?] Organizadores de Área - Geografia. SME, p.30-37.

PREFEITURA DO MUNICÍPIO DE SÃO PAULO

[1996?] Organizadores de Área - Educação Artística. SME, p.1-6.

READ, Herbert

1955 Imagen e idea. Tradução de Horacio Flores Sanches. México: Fondo de Cultura Económica, 1993. (Título original: Icon and Idea: The function of art in the development od Human Consciousness, Harvard University Press)

ROCHA, Genylton O. R. da

1992 Ensino de Geografia e a Formação do Geógrafo-Educador. Geografia, Política e Cidadania, Revista Terra Livre, São Paulo: AGB, n 11-12, p. 177-188, ago/92-ago/93.

RODRIGUES, Gelze Serrat S. C.

2001 Representações da Paisagem do Parque Nacional da Serra da CanastraMG: O Olhar do Viajante, da População Local e do Geógrafo. 98 p. Dissertação (Mestrado) - Departamento de Geografia da Faculdade de 
Filosofia, Letras e Ciências Humanas da Universidade de São Paulo, São Paulo.

ROSENDAHL, Zeny \& CORREAA, Roberto Lobato (Orgs.)

2001b Paisagem, Imaginário e Espaço. Rio de Janeiro: EdUERJ. Série Geografia Cultural $n^{\circ} 8$.

ROUGERIE, Gabriel.

1969 Géographie des Paysages. Paris: Presses Universitaires de France. Col. "Que sais-je", nº 1362.

SAMPAIO, Marisa N. \& LEITE, Lígia S.

1999 Alfabetização Tecnológica do Professor. Petrópolis, RJ: Vozes, 112 p.

SANTAELLA, Lúcia \& NÖTH, Winfried

1998 Imagem: Cognição, Semiótica, Mídia. São Paulo: Editora lluminuras Ltda.

SANTORO Jr., Antônio

[19??] Breve Análise de Uma Obra de Arte, s/inf.

SANTOS, José Ferreira dos

1980 O que é Pós-Moderno. 14ª ed. São Paulo: Editora Brasiliense S. A., 1995.

SANTOS, Milton

1982 Pensando o Espaço do Homem. São Paulo: Editora Hucitec.

SANTOS, Milton

2000 Da Cultura à Indústria Cultural. Folha de São Paulo - Caderno Mais, p.18, 19 de março de 2000.

SCARIATI, Renato

1990 Paysages Imaginaires. In: BAILLY, Antoine \& SCARIATI, Renato. L'Humanisme en Geographie. Paris: Antropos.

SILVA, Armando Corrêa da

1986 Fenomenologia e Geografia. Orientação. № 7, São Paulo: Instituto de Geografia - Departamento de Geografia, p. 53-56, dezembro/1986.

SILVA, Marisa Tsubouchi

1999 Ensino de Arte nos Estados Unidos e no Brasil. Revista Comunicação e Educação. São Paulo: Editora Moderna , n 14, jan/abr 1999, p. 49-52.

SWINGLEHURST, Edmund

1997 A Arte das Paisagens. Rio de Janeiro: Ediouro Publicações S. A. 
TARASANTCHI, Ruth Sprung.

2002 Pintores Paisagistas: São Paulo 1890 a 1920. São Paulo: Editora da Universidade de São Paulo: Imprensa Oficial do Estado.

\subsection{Catálogos e Outros}

DAN GALERIA (São Paulo, SP). Antônio Gomide: Quatro Décadas de Modernidade, out/nov 2001. Catálogo, 64 p.

ESPAÇO CULTURAL BM\&F (São Paulo, SP). Paisagens - Coleção do Museu de Arte Moderna de São Paulo: 6 de agosto a 11 de setembro de 2002. Folder.

GUIA DO REDESCOBRIMENTO (São Paulo, SP). Brasil 500 anos. Sobre a Mostra do Redescobrimento Brasil+500. Folha de São Paulo.

MILLENNIUM ART GALLERY (São Paulo, SP). Aldo Bonadei: 7 de maio a 2 de junho de 2001. Catálogo, $32 \mathrm{p}$.

MUSEU DE ARTE CONTEMPORÂNEA da Universidade de São Paulo (São Paulo, SP). Arte Naïf: O Mundo Taizi Harada e a Coleção MAC USP: 13 de novembro de 2001 a 13 de janeiro de 2002. Galeria de Arte do SESI, catálogo, 8 p.

MUSEU DE ARTE CONTEMPORÂNEA da Universidade de São Paulo (São Paulo, SP). Operários na Paulista: MAC USP e Artistas Artesãos: 17 de setembro de 2002 a 19 de janeiro de 2003. Galeria de Arte do SESI, folder e jornal.

MUSEU DE ARTE DE SÃO PAULO/The British Council (São Paulo, SP). Labdscape. Paisagem - Uma Visão Contemporânea: 29 de outubro a 9 de dezembro de 2001. Catálogo, $13 \mathrm{p}$.

MUSEU DE ARTE MODERNA DE SÃO PAULO (São Paulo, SP). Rebolo-100 anos: 22 de agosto a 6 de outubro de 2002, folder.

PINACOTECA DO ESTADO DE SÃO PAULO (São Paulo, SP). Albert Eckhout: Volta ao Brasil 1644-2003: 14 de janeiro a 30 de março de 2003. Folder. 


\subsection{Internet}

Sites consultados no período de agosto de 1999 e maio de 2003:

BOLSA de Arte. Site especializado em gravuras de diversos artistas. Disponível em: <http://www.gravura.art.br/> e <http://www.bolsadearte.com>.

CÂNDIDO Portinari. Site oficial do pintor brasileiro contendo acervo virtual de suas obras, biografia e jogos didáticos. Disponível em: <http://www.portinari.org.br>.

DAN Galeria. Apresenta reproduções de vários artistas plásticos. Disponível em: $<$ http://www.dangaleria.com.br/acervo/>.

EDITORA 4 Estações. Apresenta reproduções virtuais de vários artistas. Disponível em: <http://www.e4e.com.br/>.

FUNDAÇÃO Bienal de São Paulo. Apresenta reproduções de algumas obras de artistas nacionais além da programação cultural. Disponível em: $<$ http://www.uol.com.br/bienal/>.

GALERIA Brasiliana. Apresenta reproduções de obras de vários artistas plásticos brasileiros. Disponível em: <http://www.galeriabrasiliana.com.br.>

GALERIA Jacques Ardies. Galeria especializada em arte naïf brasileira, apresenta exposições virtuais de vários artistas. Disponível em: <http://www.ardies.com>.

HUNTINGTON Art Gallery. Apresenta exposição virtual de artistas latino-americanos. Disponível em: <www.utexas.edu/cofa/hag/ realign/gerchman.html>.

ITAÚ Cultural. Site oficial da Instituição, apresenta a programação de eventos nas diversas formas de expressão artística e uma enciclopédia de artes visuais. Disponível em: <http://www.itaucultural.org.br>

MUSEU de Arte Brasileira da FAAP. Apresenta a programação da instituição e algumas reproduções virtuais de obras do acervo ou em exposição. Disponível em: $<$ http://www.faap.br/>.

MUSEU de Arte Contemporânea da USP. Acervo digital da obra de vários artistas contemporâneos. Disponível em: <http://www.mac.usp.br>.

MUSEU de Arte da Pampulha. Site oficial do em museu mineiro com reproduções de algumas obras do acervo. Disponível em: <http://www.ciclope.com.br/map/>.

MUSEU de Arte de São Paulo. Apresenta reproduções virtuais do acervo e a programação cultural do museu. Disponível em: <http://www.masp.art.br>. 
MUSEU de Arte Contemporânea do Paraná. Apresenta reproduções virtuais de parte do acervo. Disponível em: <www.pr.gov.br/celepar/seec/ mac/obramac2.html>.

PINACOTECA do Estado de São Paulo. Site oficial da Pinacoteca com a programação cultural da instituição e reprodução de algumas obras do acervo. Disponível em: <http://www.uol.com.br/pinasp>.

PRO Arte Galeria. Apresenta reproduções virtuais e biografia de vários artistas plásticos. Disponível em: <www.proartegaleria.com.br>.

PRODAM. Apresenta reproduções virtuais das obras do acervo da prefeitura municipal de São Paulo. Disponível em: <sampa3.prodam.sp.gov.br/ccsp/ virtuais/xilos/expo08.htm>.

RANCHO La Puerta. Site de um hotel fazenda que apresenta reproduções virtuais de algumas obras de artistas brasileiros. Disponível em: <www.rancholapuerta.com/ More/arttour.html>.

SECRETARIA de Estado da Cultura do Rio de Janeiro. Apresenta links para webmuseu, com acervo virtual de obras de vários museus do estado do Rio de Janeiro. Disponível em:<www.sec.rj.gov.br/webmuseu>.

TARSILA do Amaral. Site oficial da artista brasileira com reproduções virtuais de algumas obras e biografia. Disponível em: <http://www.tarsiladoamaral.com.br>. 
Apêndices 
Apêndice A-Roteiro final

\section{ROTEIRO DE ATIVIDADES PARA ESTUDO DA PAISAGEM GEOGRÁFICA}

Atividade A: "Desenhando e pintando a vista da janela"

Objetivo: Expressar a percepção da paisagem através do desenho e da pintura.

Procedimentos: Os alunos deverão desenhar e pintar com giz de cera, a vista da rua que se vê da frente da escola. A observação pode ser realizada pela janela da sala, se houver visão da rua, ou levar os alunos para a rua, na frente da escola.

Não falar em paisagem nesta parte da atividade, apenas orientá-los a escolher um lado da vista da rua e desenhar e pintar a partir da observação.

Não será dada orientação estética ou qualquer tipo de orientação que dirija ou conduza o olhar do aluno sobre a "vista"/paisagem.

O aluno terá liberdade de realizar uma representação enumerativa, imaginativa, expressionista, rítmica, etc (READ, 1958) de acordo com sua capacidade de expressão.

Tempo previsto: 20 a 30 min.

Atividade B: "Diagnóstico de paisagem e seus elementos" (Exercício escrito 1) Objetivo: Avaliar e diagnosticar o conceito de paisagem dos alunos e sua percepção sobre a paisagem do entorno da escola.

Procedimentos: Responder as questões do exercício escrito 1 individualmente.

Tempo previsto: 15 a 20 min.

\section{Atividade C: $\mathrm{O}$ que é paisagem?}

Objetivo: Desconstruir possíveis equívocos sobre o conceito de paisagem (a necessidade de ser belo e da natureza natural) e identificar um conceito mais adequado de paisagem delimitando diferenças entre o urbano e o rural.

Procedimentos: Discussão dirigida com o grupo todo com intervenção e exposição do professor.

Avaliar conjuntamente com os alunos as respostas dadas ao exercício 1 , quanto ao conceito de paisagem e elementos. Apresentar os quadros sugeridos 1, 2 e 3 (ou outros) a fim de fazer uma relação entre os elementos pintados e desenhados da paisagem da frente da escola com os elementos das paisagens pintadas. Identificar as funções das paisagens.

Observação de quadros 1,2 e 3.

Tempo previsto: 15 a $20 \mathrm{~min}$.

Atividade D: Paisagem e uso do solo: leitura gráfica

Objetivo: Verificar o uso do solo em áreas rurais e urbanas identificando as áreas com cores diferentes.

Procedimentos: Construção de interpretação gráfica do uso do solo dos quadros 2 e 3 com papel vegetal, delimitando áreas com construções (casa, edifícios, armazéns, fábricas, etc) em laranja, áreas verdes (plantações, florestas, árvores isoladas, pastos, jardins) em verde, vias de circulação (ruas, avenidas, caminhos, 
pontes, viadutos, etc.) em marrom, águas (rios, lagos, mar) em azul escuro e o céu em azul claro. Construir a legenda.

Tempo previsto: $35 \mathrm{~min}$

Atividade E: Paisagem e uso do solo: urbano e rural

Objetivo: Avaliar como é o uso do solo no urbano e no rural e construção conjunta do conceito de paisagem urbana a partir da função dos seus elementos.

Procedimentos: Discussão dirigida sobre os resultados da parte D e ênfase nos porquês da transformação da paisagem.

Tempo previsto: 15 min.

\section{Atividade F: Por que a paisagem muda?}

Objetivo: Identificar nos quadros 1 e 2 elementos da paisagem geográfica implícitos nas representações e interpretações dos pintores.

Procedimentos: Aplicar o exercício 2 em grupos destacar da observação dos quadros 1 e 2 elementos da paisagem geográfica que se transformaram durante 0 processo de construção da paisagem.

Tempo previsto: 35 min.

\section{Atividade G: Novo olhar sobre o desenho e a pintura}

Objetivo: Destacar a importância da paisagem como gênero da pintura, orientar os alunos sobre como pintar e desenhar paisagens e despertar o interesse deles sobre a biografia dos pintores.

Procedimentos: Dicas de uso de cores e como representar a profundidade. Identificar alguns gêneros da pintura a partir da observação de reproduções de quadros e conversar sobre a biografia dos pintores.

Tempo previsto: $15 \mathrm{~min}$.

\section{Atividade H: Novo olhar sobre a paisagem}

Objetivo: Redesenhar e repintar a paisagem da janela ou da frente da escola.

Procedimentos: Levar os alunos novamente para a frente da escola ou para uma observação pela janela da sala de aula para que desenhem e pintem novamente a paisagem vista na frente da escola.

Tempo previsto: $20 \mathrm{~min}$.

\section{Atividade l: Avaliação final}

Objetivo: Verificar se houve mudança no conceito e na percepção da paisagem.

Procedimento: Aplicar o questionário com 5 questões para resposta individual.

Tempo previsto: 15 min. 


\section{Apêndice $B$ - Atividade Complementar 1}

Nome dos integrantes do grupo:

Série: Data:

\section{Quadro 1}

1. Qual é o título do quadro?

2. Quando o quadro foi pintado?

3. Qual é o nome do pintor do quadro?

4. Qual o material utilizado para pintar esse quadro?

5. Quais são as cores que predominam no quadro?

6. Que tipos de linhas predominam no quadro: horizontais, verticais, inclinadas, curvas ou não há linhas claramente definidas?

7. Há relação entre o título do quadro e o conteúdo? Por que?

8. Qual é a opinião de vocês sobre o quadro ou o que vocês acharam dele?

9. A paisagem do quadro é parecida com a paisagem que vocês pintaram? Por que?

10. Aponte uma característica de paisagem urbana nesse quadro:

11. Vocês já conheciam esse quadro?

12. Vocês já conheciam esse pintor? 
Atividade Complementar 1 (continuação)

1. Qual é o título do quadro?

Quadro 2

2. Quando o quadro foi pintado?

3. Qual é o nome do pintor do quadro?

4. Qual o material utilizado para pintar esse quadro?

5. Quais são as cores que predominam no quadro?

6. Que tipos de linhas predominam no quadro: horizontais, verticais, inclinadas, curvas ou não há linhas claramente definidas?

7. Há relação entre o título do quadro e o conteúdo? Por que?

8. Qual é a opinião de vocês sobre o quadro ou o que vocês acharam dele?

9. A paisagem do quadro é parecida com a paisagem que vocês pintaram? Por que?

10. Aponte uma característica de paisagem urbana nesse quadro:

11. Vocês já conheciam esse quadro?

12. Vocês já conheciam esse pintor? 
Apêndice C-Atividade Complementar 2

\section{A PAISAGEM GEOGRÁFICA NA PAISAGEM PINTADA}

Nome dos integrantes do grupo:

Série: Data:

1. Qual é o título do quadro?

2. Qual o nome do pintor?

3. Quando o quadro foi pintado?

4. Escolha uma frase (ou mais de uma) de qualquer um dos textos que explique a paisagem do quadro:

5. Por que vocês escolheram essa frase? 


\section{Apêndice D - Avaliação do professor}

\section{ROTEIRO DE AVALIAÇÃO PARA O PROFESSOR}

Professor:

Escola:

Data:

1. Avalie os diversos momentos e instrumentos da atividade aplicada:

1.1. quanto ao material utilizado:

- qualidade das reproduções:

- qualidade do material de desenho:

- textos (se houver):

- elaboração das folhas de exercícios:

- você conhecia os quadros?

- você conhecia os pintores?

1.2. quanto à duração e pertinência das atividades:

- Atividade A:

- Atividade B:

- Atividade C:

- Atividade D:

- Atividade E:

- Atividade F:

- Atividade G:

- Atividade $\mathrm{H}$ :

- Atividade I:

1.3. quanto à reação dos alunos em comparação ao dia-a-dia nas aulas de Geografia, houve - mudança de comportamento?:

- mudança no grau de assimilação?:

- mudança no grau de interesse?:

- outras?:

1.4. para o professor:

- o que você faria diferente?:

- aspectos negativos:

- outras observações:

2. Você já havia combinado algum tipo de expressão artística com Geografia na sua prática didática? Se sim, qual e como foi?

Se não, por que?

3. Qual a sua opinião sobre a articulação entre Arte e Geografia no ensino? 
4. Qual o grau de dificuldade em realizar essa articulação sem a ajuda do Professor de Artes?

5. Você já realizou alguma atividade em conjunto com professores de outras áreas de conhecimento? Se sim, com professores de quais áreas?

Se não, por que?

6. Você avalia que houve algum tipo de contribuição da Arte para o aprendizado em Geografia nessa atividade?

Se sim, qual?

Se não, por que?

7. Você avalia que houve algum tipo de contribuição da Geografia para o aprendizado em Arte nessa atividade?

Se sim, qual?

Se não, por que?

8. Se você tivesse acesso a um conjunto de materiais didáticos de artes (como reproduções de quadros) você utilizaria na sua prática didática?

9. Você avalia que houve uma mudança no entendimento dos alunos sobre o conceito de paisagem? 
Anexos 


\section{Anexo A - Textos da Atividade Complementar 2}

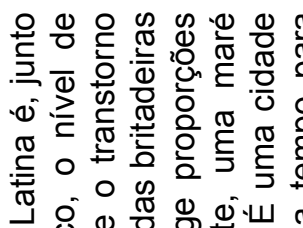

0 은

U.ष

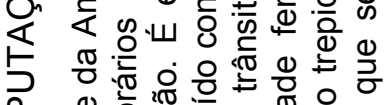

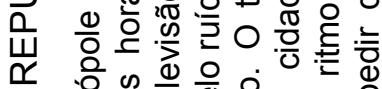

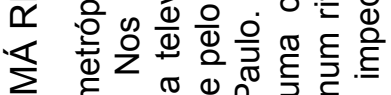

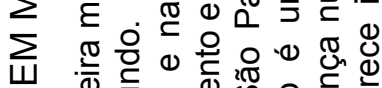

Ш

○

ব)

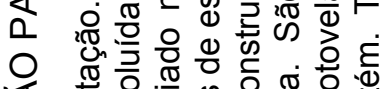

《

ஸ

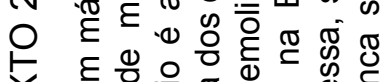

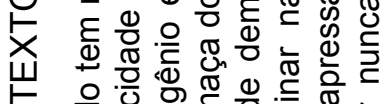

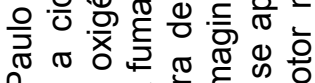

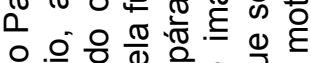

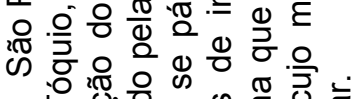

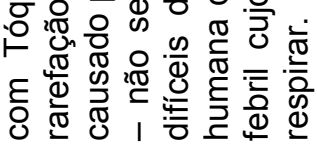

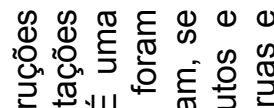

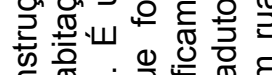

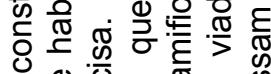

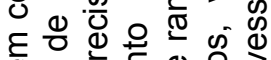

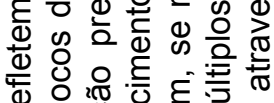

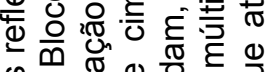
\&

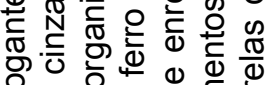

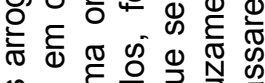

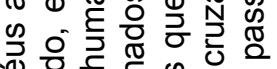

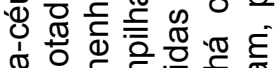

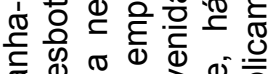
휴 远

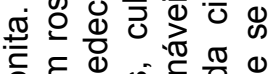
ธิํำ ๑) की זে

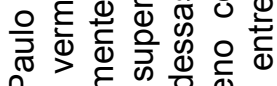

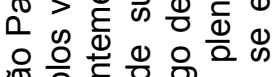
๙

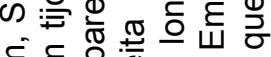

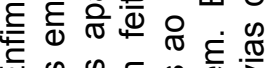

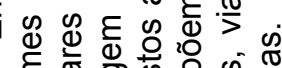

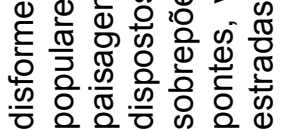

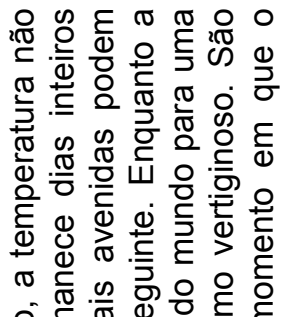

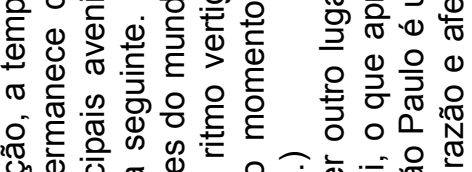
ชั 递亲

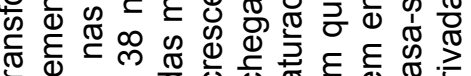
సٓ 을 :

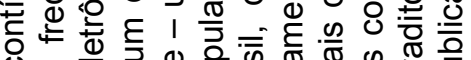

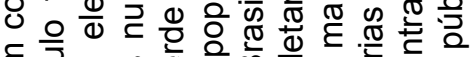
ब

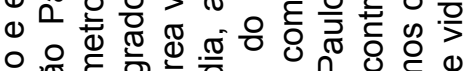
윰 ๙ बे क人

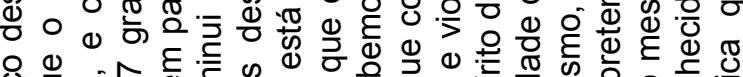

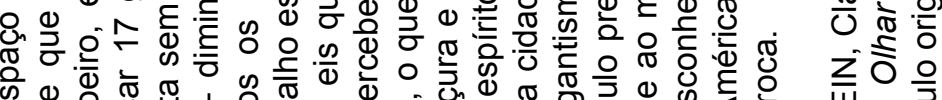
की

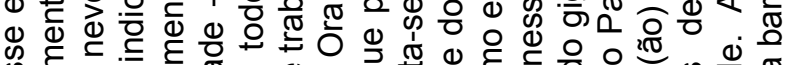

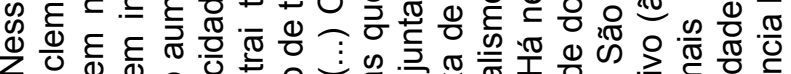

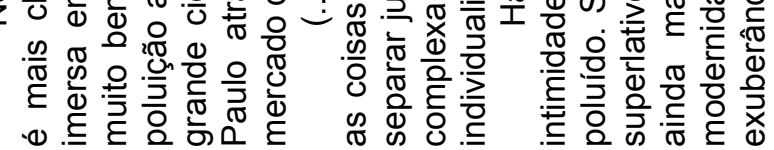

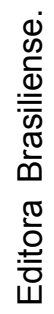

$\frac{0}{\sqrt{0}}$

กิ i 这 둥 ํํㅇ Z绾 这은 임 4 क 0 め Шே! 世 щ ○요 $\cong$

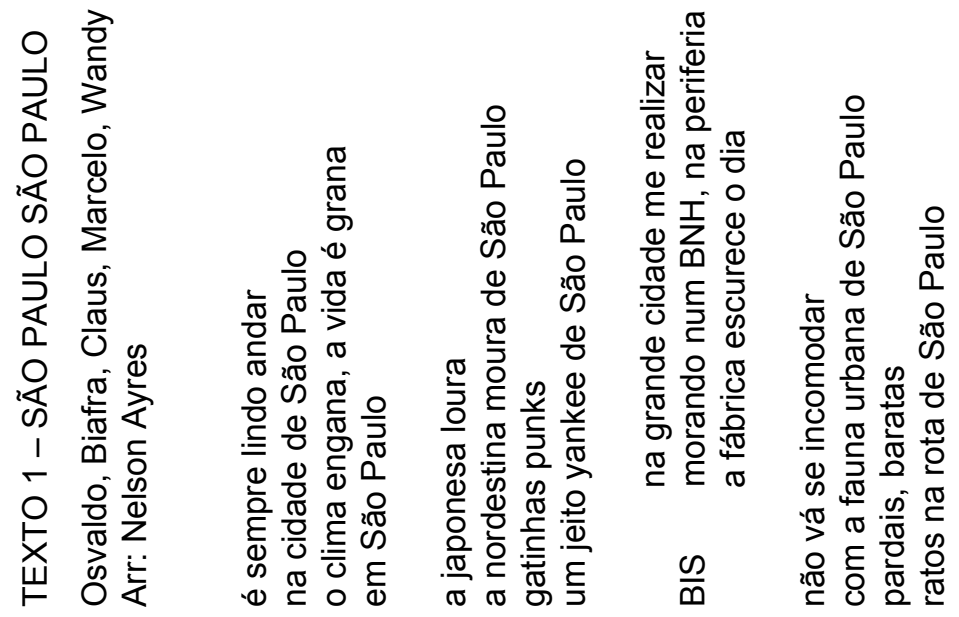

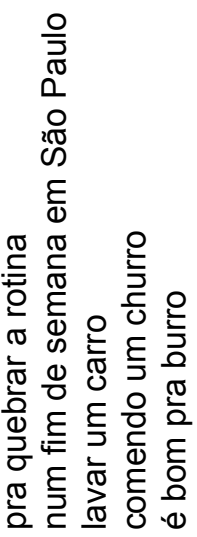


Anexo B - Modelo de Reprodução de Quadro
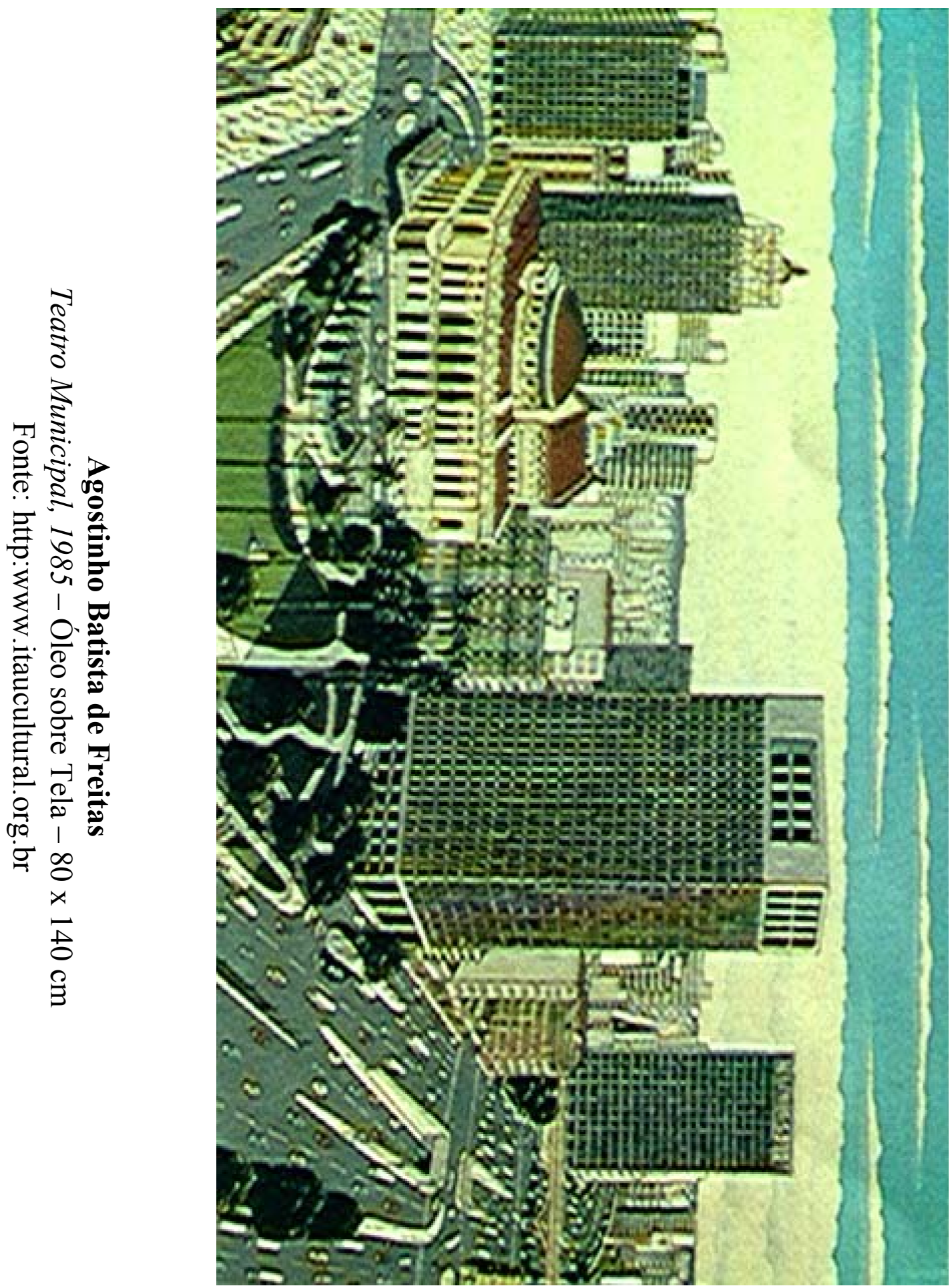


\section{Encarte}

Instruções para assistir às apresentações:

- vá ao Windows Explorer (Explorar/explorando)

- duplo clique no drive do compact disc

- duplo clique no ícone azul da apresentação escolhida (tipo aplicativo):

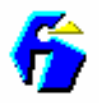

- use ESC se quiser sair da apresentação antes do final

\section{Configuração mínima:}

- Windows 95

- Pentium

- drive CD-Rom 4x 